\title{
Essays on Women's Empowerment in Developing Countries
}

Dissertation

In order to acquire the doctoral degree

from the Faculty of Economic Science,

at the Georg-August-Universität Göttingen

Submitted by

Debosree Banerjee

Born in 23.04.1981

Göttingen, July 2014

Thesis committee

Prof. Stephan Klasen

Prof. Marcela Ibanez

Prof. Matin Qaim 


\section{Table of Contents}

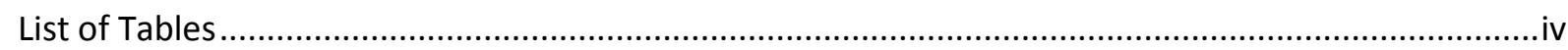

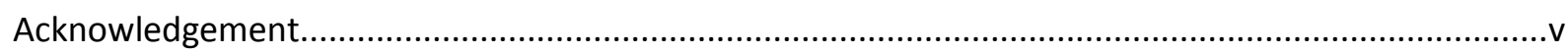

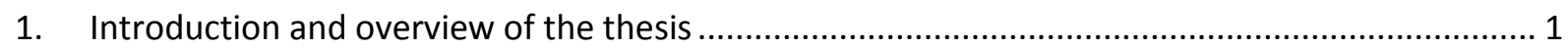

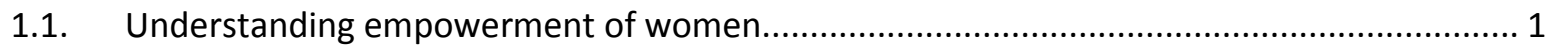

1.2. Market discrimination, market participation and control over revenue: A gendered analysis

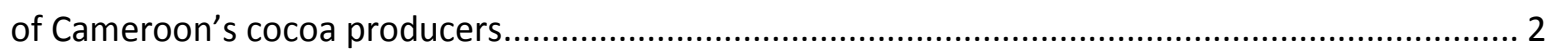

1.3. Running for leadership: evidence from an artefactual field experiment in matrilineal and

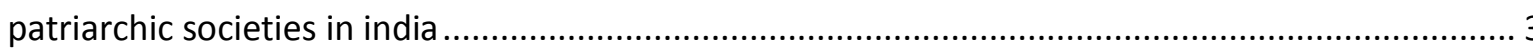

1.4. Ethnicity and gender differences in risk and ambiguity attitude ........................................ 6

2. Market discrimination, market participation and control over revenue: A gendered analysis

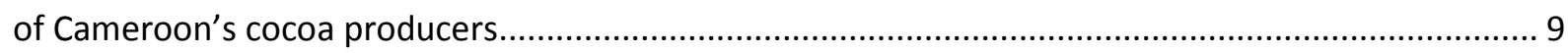

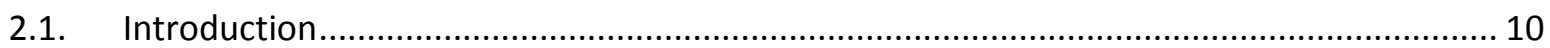

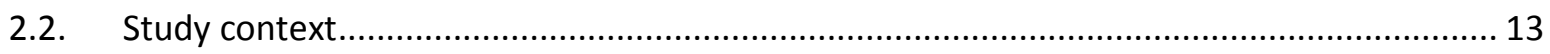

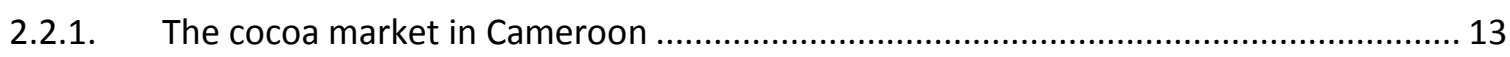

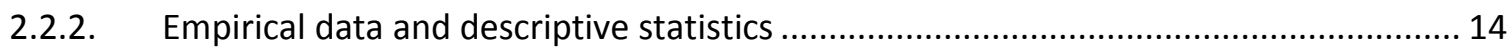

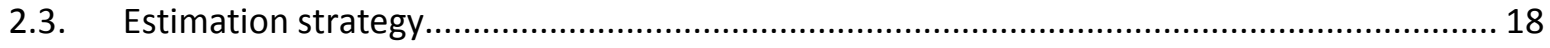

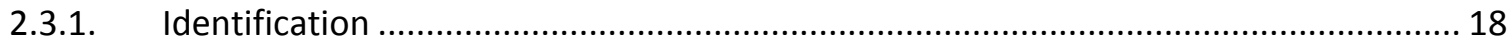

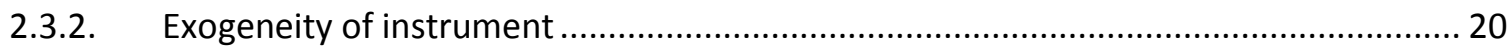

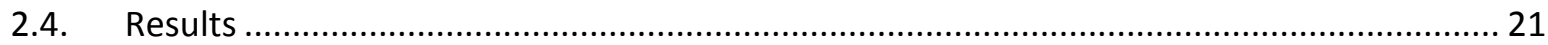

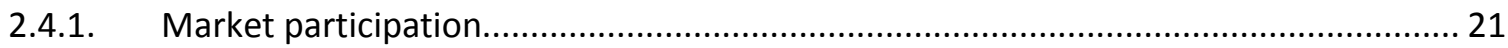

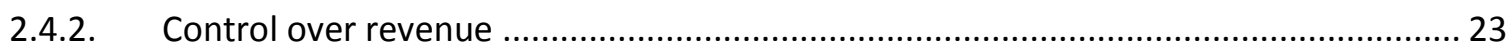

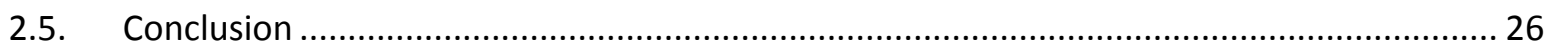

3. Running for leadership: evidence from an artefactual field experiment in matrilineal and

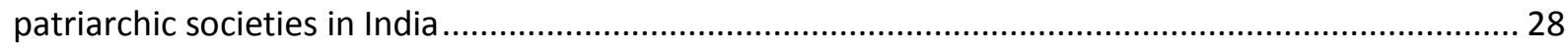

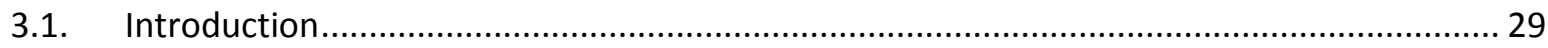

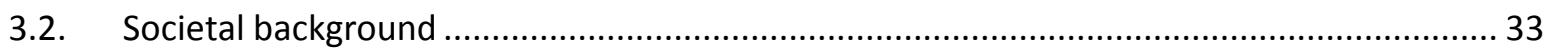

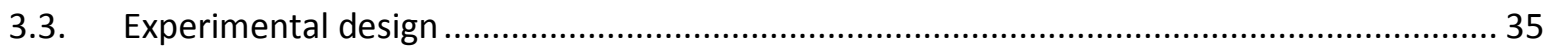

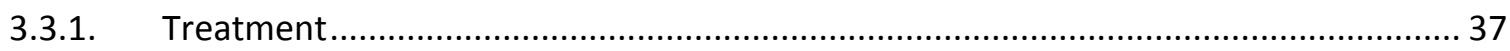

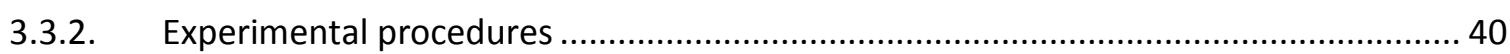

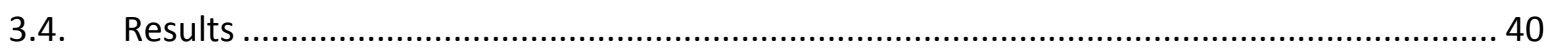

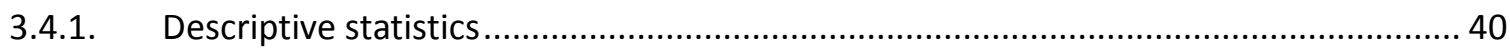

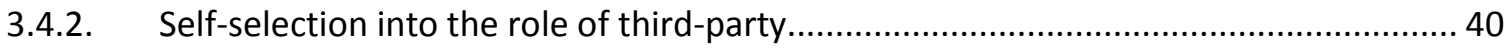

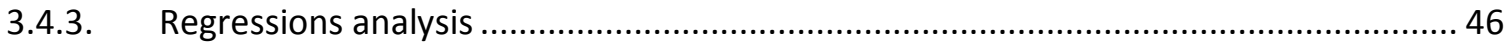


3.4.4. Characteristics of participants who self-select in the role of third party.......

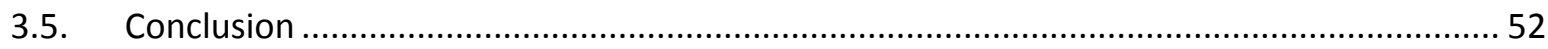

4. Ethnicity and gender differences in risk and ambiguity attitude ............................................. 54

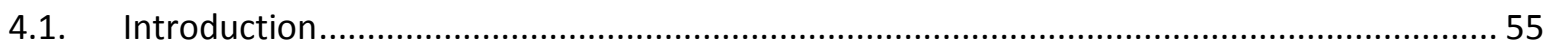

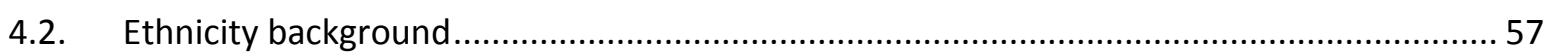

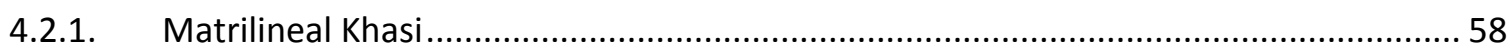

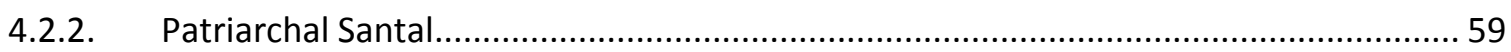

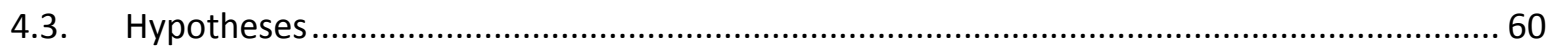

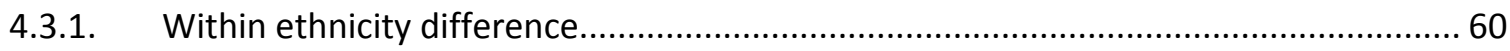

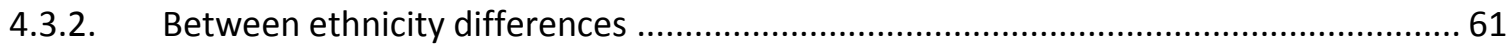

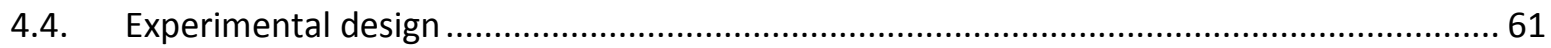

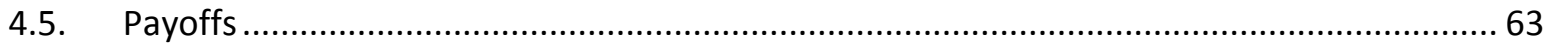

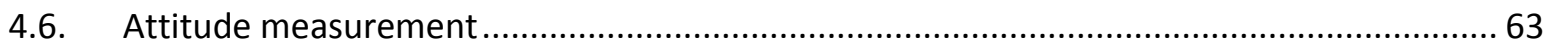

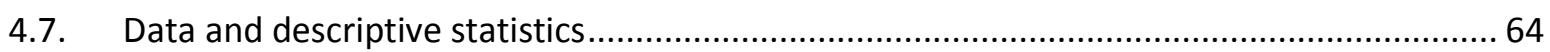

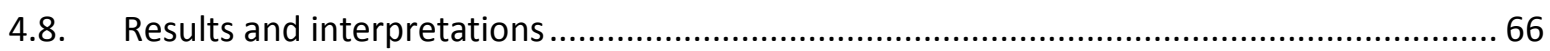

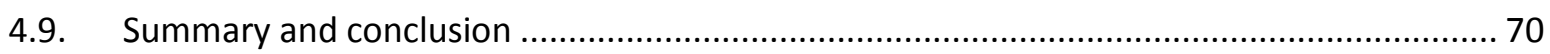

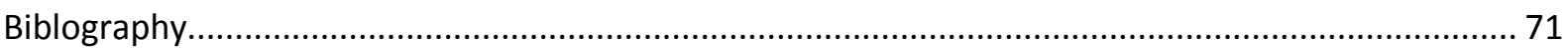

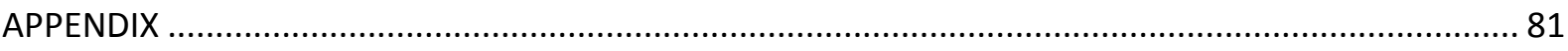

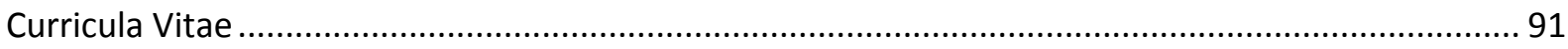




\section{List of Tables}

Table 2.1: Descriptive statistics of individual characteristics by gender .............................................. 16

Table 2.2: Share of revenue controlled by market participation and gender ..................................... 17

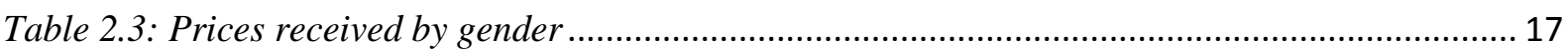

Table 2.4: Market participation in villages with and without male farmers selling through CIGs ...... 20

Table 2.5: Determinants of market participation ............................................................................. 22

Table 2.6: Instrumental variable analysis of control over cocoa revenue ............................................. 25

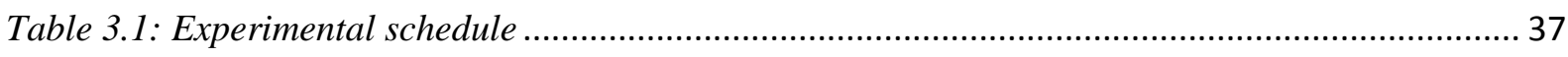

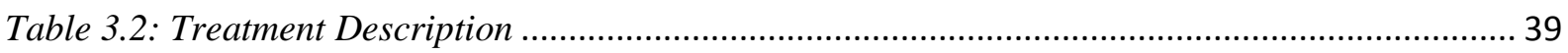

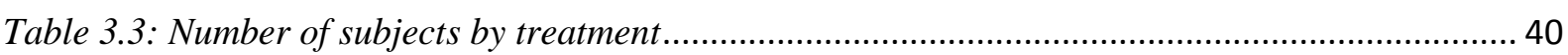

Table 3.4: Socio-economic characteristics and randomization check ............................................. 42

Table 3.5: Proportion of subjects applying for punisher by society and gender .................................... 44

Table 3.6: Proportion of subjects applying for punisher by society, gender and wage ........................ 46

Table 3.7:Marginal effects of choice of leadership application from a linear probability model ........ 47

Table 3.8: Random effect regression on application by gender and society depending on wage ......... 49

Table 3.9: Characteristics of Applicants vs. Not Applicants............................................................. 51

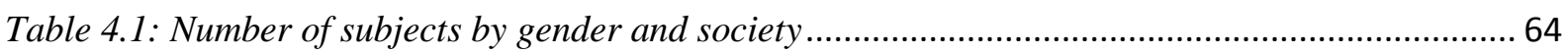

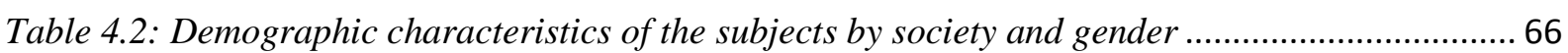

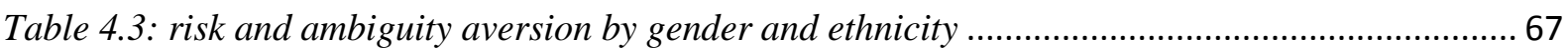

Table 4.4: Within ethnicity gender differences (male-female) in risk and ambiguity attitude .............. 68

Table 4.5: Ethnicity (matrilineal -patriarchal) differences in risk and ambiguity attitude .................. 69

Table A.1: Testing for the exogeneity of \% of male farmers selling collectively in village .................. 81

Table A.2: First stage regression results of IV models presented in Table 2.6................................... 82

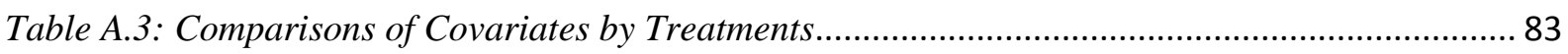

Table A.4: OLS estimation of risk and ambiguity attitude with socioeconomic controls...................... 88 


\section{Acknowledgement}

I am deeply indebted to my advisors: Prof. Stephan Klasen, Prof. Marcela Ibanez and Prof.

Meike Wollni for their valuable suggestions and supervision. Without their support and constructive criticisms this work would not have been succeeded. My utmost gratitude goes to my main advisor, Prof Stephan Klasen for allowing me to work with him, his time, patience, and most importantly for his kindness. Meeting Prof. Klasen for supervision not only helped me in my thesis but constantly made me confident about my capabilities. This is truly a unique experience for me.

I would like to thank Prof. Marcela Ibanez, Prof. Gerhard Reiner and Prof. Meike Wollni for making me understand the true rigor behind good quality research, in terms of why researching an issue, how to carry on the research, writing and finally defending the research. I would also like to thank the Research Training Group of GlobalFood at the University of Göttingen, especially the chairperson, Prof. Matin Qaim and the head of coordination office, Dr. Melanie Grosse for facilitating the research atmosphere; organizing the time frame and the courses and providing guidance in all official issues.

Finally, I am thankful to my family and friends, Maa, Baba, Jhuma, Debasis, Arunasis, Ramona, Amjad for constantly encouraging me in my research. 


\section{Introduction and overview of the thesis}

\subsection{Understanding empowerment of women}

There has been a spur of studies attempting to define the concept of women's empowerment. But the meanings and terminologies associated with this concept still vary. For example, it is not always clear whether terms such as "women's empowerment," "gender equality," "female autonomy," or "women's status" are referring to same or different concepts. Nonetheless, the concept of women's empowerment can be distinguished from others by two defining features. The first is process (Kabeer, 2001; Oxaal and Baden, 1997; Rowlands, 1995) of change towards greater equality and increased ability and freedom to make choices. The second is agency in which women themselves are the actors in the process of bringing changes (Malhotra and Schuler, 2005). Lately the agency issue has started to receive more attention and women no longer remain as passive recipient of welfare enhancing help. Instead they are being seen as active agents of economic and social changes altering lives of both men and women. The focus of agency role of women has direct bearing on women's welfare in terms of ability to make strategic life choices, but its reach goes beyond that in areas such child survival, decreasing fertility etc. (Sen, 1999).

Empowerment of women has been widely acknowledged as an important target in international development. There are two main rationales supporting active policies on women empowerment (Duflo, 2011). First, women are currently worse off than men in dimensions of wellbeing in most developing countries and such inequality is not desirable. This was pointed out by Kofi Annan, the Secretary General of the United Nations in the United Nation's 2005 report on the Millennium Development Goals (MDG): "The full participation of women to all levels of decision-making is a basic human right." Second, from the point of view of the policy making, women play a crucial role in development. Studies suggest that putting earnings in women's hands is desirable to speed up development as women usually reinvest a much higher portion in their families and communities than men, spreading wealth beyond themselves (Gertler, 2004; Janvry and Sadoulet, 2006). Thus women's empowerment is a prerequisite to achieving the other MDGs (World Bank, 2001, 2011).

A large number studies in economics have attempted to empirically measure various aspect of women's empowerment. A majority of them seem to develop a common consensus on certain factors promoting women's empowerment, such as, education, labor force participation, microcredit etc. (Sadik, 1993; Bradley and Khor, 1993; Mason, 1986; Malhotra and Mather, 
1997; Hashemi et al., 1996). Malhotra and Schuler (2005) in their study have provided a comprehensive overview of factors playing positive role in empowering women economically. They segregated these factors at three different unit of observation levels: (1) household level factors, such as, control over income; ownership of assets, land and family resources and contribution to family support (2) community level factors, such as, access to employment, credit, market; representation in local level organizations and finally (3) at broader areas, such as, representative at the high paying jobs; representation of women's interest in macro level policies and budgets.

In our study, we attempt to discuss some of these elements in three different essays. In the first essay, we discuss how access to agriculture market by female farmers in Cameroon could improve their own control over the proceeds of their agricultural output. Scope of this research falls in the general category of household and community level factors affecting women's empowerment. In the second and third essay discuss aspects of participatory development in India in areas ranging from community development to hierarchical institutes and politics. We concentrate on two aspects of participatory development: One is underrepresentation of women in leadership; and second is gender differences in leadership style with respect to their risk and ambiguity attitude. For the purpose of the thesis we restrict ourselves only to developing countries where gender differences are more pronounced.

Next three sections of the introduction provide a comprehensive discussion on the specific research objectives, contributions and findings of these essays.

\subsection{Market discrimination, market participation and control over revenue: A gendered analysis of Cameroon's cocoa producers}

During the last few decades, important changes have been taking place in agro-food system (Bouis \& Haddad 1990; Dorsey, 1999) in terms of processing, wholesale and retail. Such transformation in global food system has been increasingly integrating domestic farmers to the local as well as international markets. However, while a large number of studies have confirmed the welfare role played by agri-food transformation, relatively lesser number of studies analyzed the issue of underrepresentation of women in agricultural markets. Female farmers suffer from serious disadvantages when it comes to the opportunities to participate in markets due to factors, such as, lower adoption of new technologies, lower access to extension service, lower integration with marketing channels etc. which then reduces their access to income(Blackden \& Bhanu, 1999; Blackden et al. 2007; Kumase et al., 2008). 
In our study, we investigate the impact of market participation on women empowerment measured as increased control over agricultural proceeds. Unlike other studies which discuss unequal access to resources as a critical factor lowering intrahousehold status for women, we investigate lower market participation as another factor contributing to intrahousehold inequality which potentially hurts women. Previous studies have identified the welfare effect of market participation in terms of increased income. Yet it has not been explained what determines the control over income. Our study fills this gap using micro level data for 911 male and female cocoa farmers from Cameroon. We test for two specific hypotheses (1) collective marketing fosters market participation in agricultural markets and helps to reduce price discrimination in output markets; (2) market participation affects control over cocoa revenue positively, where control over revenue is measured by the proportion of revenue controlled by the farmers individually. Methodologically, our study has to contend with the possibility that unobserved factors that affect female participation in marketing also affect female control over the resources which could lead to bias in the estimations. We address this problem by exploring exogenous variation in collective marketing activities at the regional level.

Our findings show that market participation renders higher control over cocoa proceeds. However, female market participation is hindered by price discrimination in cocoa market of Cameroon. Female farmers receive significantly lower price than their male counterparts in cocoa markets and in order to obtain higher prices they handover the task to another family member, preferably a man. As a result the individual carrying out marketing could have a share in revenue which then reduces farmers' own control over the proceeds. On the other hand, control over the revenue is significantly higher for farmers who take up marketing on their own. Collective marketing reduces the gender gap in prices as price received by farmers under collective sell does not vary across gender. This leads to increased female participation in marketing and higher control over agricultural proceeds. We therefore conclude that the development of collective marketing plays a critical role in improving female intrahousehold bargaining power calling for the attention of policy makers towards strengthening of collective actions.

\subsection{Running for leadership: evidence from an artefactual field experiment in matrilineal and patriarchic societies in india}

Empirical evidence suggests that participation of women in leadership positions is associated with increased provision of public goods which in turn can have important consequences for 
subsequent growth and equity (Chattopadhyay \& Duflo 2004; Chen, 2010). Nonetheless, women remain under-represented in leadership positions. For example, among the largest 500 publicly-listed companies in the US, men account for $86 \%$ of the executive positions, $84 \%$ of the boards of directors and $96 \%$ of the Chief Executive Officers. In other regions of the world, such disparities are even larger. For example, in India, among 100 companies on the Bombay Stock Exchange only $5.3 \%$ of total directorships were held by women, less than $50 \%$ of the companies had women on their boards, while 54 companies had no female representation at all (Banerji et al., 2010).

Explanation of the sparse representation of women in elite leadership roles has been traditionally ascribed to causes, such as, gender discrimination. Discrimination occurs because women are often thought to have less leadership abilities than men with similar achievements (Duflo and Topalova, 2004; Eagly and Krau, 2002). Alternatively, it has been considered that gender differences in personality traits, such as, competitiveness (Niederle and Vesterlund, 2007; Gneezy et al., 2003), risk taking behavior (Eckle and Grossman, 2002, 2008; Croson \& Gneezy, 2009), bargaining power (Kray et al., 2001,2002), confidence and competence (Eagly and Karau, 2002), could explain these differences.

In this essay we consider an alternative view and investigate, whether women are absent in leadership positions due of the lack of intrinsic motivation to assume such role. There is substantial evidence on self-segregation by women into low paid occupations. For instance Cepeda \& Baron (2012) find that that $40 \%$ of the wage gap against women in Colombia can be explained by differences in selection of degree of studies. Similar evidence is established for UK, Germany (Machin and Puhani, 2003) and Taiwan (Lin, 2010). Hence, it is plausible that women also self-segregate out from top leadership positions.

Our research contributes to the understanding of self-segregation in leadership roles by investigating the role of social norms and intrinsic motivation. Our experimental approach is based on a linear public good game with endogenous third party punishment. Hence, participants can decide whether they want to play the role of contributors or the role of third party, which would replicate a leadership position. As third parties do not benefit from contributions to the public good, the motivation to sanction contributors can be associated with willingness to become social regulator.

To investigate whether gender differences in willingness to assume positions of leadership is innate or is given by social norms, we compare societies that vary in terms of the empowerment of women. In particular, we conducted the experiment in two different states of 
India, namely Meghalaya and West Bengal, with the local tribes known as Khasi and Santal. These two tribes differ from each other with respect to their intra-society power structure. In the patriarchal Santal society men are the major decision-makers, while in matrilineal Khasi, women are the dominant gender.

Our experimental design explores the presence of two different motivations that affect the leadership choice by women: conformity with the social norms and aversion to feedback. The first motivation relates to situations where there are concerns on social perception on the appropriateness of roles assumed by men and women in the society. To assess the effect of conformity with social norms, we compare scenarios in which the degree of anonymity varies exogenously. In the experimental set this is achieved by comparing public leadership versus anonymous leadership. The second motivation that we address is aversion to feedback or aversion to retaliation.

Finally, we examine the effectiveness of two different policy instruments to promote women to take leadership roles: 1) Affirmative action and 2) increase in leadership wage. Affirmative action has been utilized by policy makers as an effective tool to promote women's participation in leadership. It has been found to be effective as affirmative action could bring change in perception about women in leadership role and also encourage women participation in leadership roles (Duflo and Topalova, 2004; Ibanez, Riener, Rai, 2014). By examining affirmative action we could additional establish effectiveness of such instruments across societies that are culturally different. Similarly, we examine impact of higher pecuniary incentive on leadership inclination of subjects and its effectiveness in attracting women to the leading role. We find positive impact of affirmative action in patriarchal society and a detrimental effect in matrilineal society. Finally, we find that pecuniary incentives promote females and males to opt in to the power position, however, our evidence also suggest that higher remuneration crowds out voluntary motivation to take the power role and is less effective than affirmative action incentives.

Our study supports three major findings. First while women in patriarchal society are significantly leadership averse in matrilineal society they show higher inclination towards leadership. However, once we introduce anonymous leaders and make the social norms silent we find a convergence in female preferences with respect to leadership choice in these two societies. Finally, we find that affirmative action is an effective policy to promote female leaders in patriarchal society, while it discourages female leadership in matrilineal societies. 
Therefore, we conclude in a country like India with societal diversities policies, such as affirmative action, instead of central level, should be taken up at the state level.

\subsection{Ethnicity and gender differences in risk and ambiguity attitude}

Economic studies on participatory development and gender so far have followed a two-stage approach. At the initial stage, a large number of studies were conducted to understand inclusion of women in leadership role and its welfare implications for women's empowerment (Adhikari and Lovett, 2006; Agarwal, 2001; Kabeer, 1994; Moser, 1993). These studies concluded that participation, in general, is welfare improving, and in particular, has generated higher socio-economic status for women. Very recently, further attempts were carried out to analyze the dilemma of participation and effective participation (Agarwal, 2001) which relates more to the decision making style of women in leading role. The third essay of the thesis investigates particular aspects of effective participation in terms of gender differences in leadership style with regard to risk and ambiguity attitude.

The main idea we pose in this essay is that being a leader in a group often involves taking decision on behalf of a group that affects payoff of others. The outcomes of these decisions are not certain and depend on the probability of success. Examples of such decisions might be making investment decisions on behalf of group; or introducing new machines in a factory whose probability of success depends on the unobserved ability of workers to adapt to the technical changes. While the first example relates to the risk attitude of the leader, second depends on the ambiguity attitude. The difference between risk and ambiguity, as defined in experimental economics is that, in the first the probability of success is known; while in the second probabilities are unknown.

In experimental economics a stylized findings is women are more risk averse than men (for survey see Charness and Gneezy, 2012; Croson and Gneezy, 2009; Eckel and Grossman, 2008). On ambiguity attitude, some studies also found similar evidence of gender difference (Jianakoplos and Bernasek, 1996, Barsky et.al., 1997, Powell and Ansic, 1997). In our research we attempt to understand the gender difference in leadership style with respect to risky and ambiguous choice. In other words, we explore whether the gender difference that is found in the individual context prevails when men and women are in a leadership role.

In order to achieve our research objective, we use the framework of Ellsberg's (1961) two color game on risk and ambiguity attitude. In the game participants are faced with a choice between a gamble and a certain amount. We use a simple gamble of drawing a ball from a bag 
containing pink and yellow balls, but guessing the color before the draw. In case of correct guess subjects received the gamble prize, otherwise nothing. Alternatively, they might decide not to opt for gambling and take the certain amount indicating their aversion toward risky or ambiguous decisions. In the risk game subjects are aware of the exact proportion of colors in the bag in the ambiguity game they remain unaware of the proportion.

The specific contributions of this experiment relates to how we analyze leadership. We introduce leadership in an experimental induced treatment and then compare the risky and ambiguous choices of the subjects from two different cultural backgrounds. In the first case, each individual plays two variants of the same game; first they play for themselves, in which payoff is received individually and then for their groups, determining the payoff of all group members. Outcomes are then compared in four cases: individual risk, group risk, individual ambiguity and group ambiguity. Second, we tested whether the gender differences in risk and ambiguity attitude could be attributed to nature or nurture. For our purpose, we implemented the same experiment with 604 subjects from two different ethnic groups in India. One of these ethnicities is a matrilineal tribe known as Khasi and the other is a patriarchal tribe known as Santal. These tribes differ from each other with respect to their intra-cultural gender norms with women being the social head in Khasi and men being in main gender in Santal.

We expect gender difference in risk and ambiguity attitude to exist in both societies, however, the direction of difference should be opposite. In other words, we hypothesized that matrilineal women will have a higher risk and ambiguity taking attitude than men; but patriarchal women will have higher risk and ambiguity aversion. We conjecture such outcomes because matrilineal women and patriarchal men hold similar social status in their respective societies. We also hypothesized that between these tribes matrilineal women will be significantly more risk and ambiguity taking than the patriarchal women because of the former plays a more critical role in the society in terms of decision making than the later. Finally we hypothesize that subjects will be significantly more risk and ambiguity averse in group decision making than in individual decision making.

Our finding shows that women, in both ethnicities, are more risk averse than men in individual choices as well as in group choices. Therefore, first conclusion we draw from our study is that gender difference in risk aversion is a common phenomenon and does not depend on the cultural background of the subjects. Also, since such difference persists not only in individual choices but also in group choices we argue that women are more risk averse than their male counter parts even when they are in leading positions. Second, on ethnicity 
difference we find that matrilineal male and female are more risk averse than patriarchal male and female respectively. Therefore, we find that there is an ethnicity difference in risk taking attitude with matrilineal subjects being more risk averse than the patriarchal subjects. This goes against our hypotheses on risk attitude of the leading gender in the society (we thought that matrilineal women and patriarchal men will be more inclined toward risky choices than the patriarchal female and matrilineal men respectively). We then conclude that such ethnicity difference in risk attitude might occur due to the differences in the economic and climatic conditions faced by the subjects. Khasi subjects are located in regions that are economically more backward than that of Santals' and they are often exposed to adverse climatic conditions or shocks. These might have caused the higher risk aversion by the Khasi subjects in the experiment. 


\title{
2. Market discrimination, market participation and control over revenue: A gendered analysis of Cameroon's cocoa producers1
}

\begin{abstract}
Using micro level data from Cameroon this paper applies the theories of intrahousehold bargaining to models in which female farmers decide whether to take up cocoa marketing on their own or to rely on others to sell the product. We analyze the effect of marketing on control over the proceeds. We find that controlling both production and marketing provides higher bargaining power over proceeds compared to a situation in which the farmer participates only in production and delegate the task of marketing to another family member. Our data also indicate that in the cocoa sector of Cameroon, female farmers' market participation is hindered by existing price discrimination, which in turn reduces their intrahousehold bargaining power. In other words, participating female farmers receive much lower prices for their produce than participating males. To generate higher revenue, female farmers hand over the marketing responsibility to a male in the family. Such non-participation results in lower control over the proceeds by the female farmer, as the individual doing the marketing can now claim a higher share in the revenue. Additionally we find that collective marketing contributes to eliminating price discrimination and promoting female market participation and thus their control over proceeds.
\end{abstract}

Keywords: Agricultural market participation, Gender, Control over income, Price discrimination JEL Code: D10, D19, D81, J16

\footnotetext{
${ }^{1}$ This paper is a joint work with Stephan Klasen, and Meike Wollni. Klasen: Department of Development Economics, University of Göttingen, Germany; Wollni: Department of Agricultural Economics and Rural Development, University of Göttingen, Germany. We would like to thank Wokia Kumase for providing us the data and all the background information on cocoa producing farmers in Cameroon. We also thank Marcela Ibanez and all participants of GlobalFood symposium, 2014 for valuable discussion and comments. Finally, we thank the DFG for funding this research as a part of GlobalFood Research.
} 


\subsection{Introduction}

A fundamental issue in microeconomics with particular relevance to developing countries is how to model household behavior when systematic differences in preferences exist. Undoubtedly household decisions, such as who works for how many hours, how to generate income, and who receives how much of the household resources, are the outcome of intrahousehold decision making and have crucial implications for individual welfare. It has been shown that household members with higher bargaining power have more influence on decision making than members with less bargaining power (e.g. Sen, 1990; Thomas 1997, World Bank 2001, Klasen, 1998). Therefore, intrahousehold bargaining ${ }^{2}$ and associated intrahousehold outcomes have generated great interest among researchers and policy-makers concerned about the well-being of women and children, which is largely dependent on the outcome of this intrahousehold bargaining.

The empirical literature has confirmed that women with lower bargaining power tend to have less access to household resources, such as resources allocated to health, education and access to land, than their male counterparts (Thorsten, 2002; Udry etal, 1995; Chiappori, 1988, 1992; Browning \& Chiappori, 1998; Klasen, 1998). Second, causal association between bargaining and household decision-making in the allocation of resources flows both ways. Unequal access to resources affects bargaining and then lower bargaining power causes lesser access to household resources (Basu, 2006). Therefore, persistence of a gender gap in intrahousehold bargaining could be attributed to gender gaps in access to any income generating activities or access to assets and unearned incomes (Rocheleau \& Edmunds 1997; Rose \& Hartmann 2004, Thomas, 1997). Furthermore, such differences tend to be even stronger in rural economies where family and community norms regarding the accumulation and transmission of wealth are important to determine the within-household wealth allocation, which in turn affects the bargaining power of male and female household members. Under these customary norms in many rural settings in developing countries, production systems favor male over their female counterparts in terms of access to productive resources, such as land, which then translates

\footnotetext{
${ }^{2}$ Intrahousehold bargaining models are typically modeled within a cooperative bargaining framework. A typical cooperative bargaining model of marriage starts with a family consisting of only two members: a husband and a wife. Individual agents, whose utility depends on their consumption of a private good, bargain with each other and depending on their relative bargaining strength, family demand is determined. If agreement is not reached between spouses, then the payoff received is represented by the utilities associated with divorce or a non-cooperative equilibrium within marriage, which are often known 'threat points'; as a result, bargaining outcomes within marriage depend on this threat point as this circumscribes the bargaining solution (Manser-Brown, 1980 and McElroy-Horney, 1980, 1990, Chiappori, 1992 and Browning \&Chiappori, 1998). Recent empirical tests of predictions of household models have strongly supported the role of bargaining power for household decisions, while debates continue whether the outcome of bargaining is pareto efficient or not (e.g. Browning and Chiappori, 1998; Haddad, Hoddinott, and Alderman, 1997).
} 
into lower productivity and income levels for female-headed farm units (FAO, 2011; IFAD, 2011; Quisumbing \& Pandolfelli, 2010; World Bank, FAO, \& IFAD, 2009).

While unequal access to productive resources has well been discussed in the literature to address the gender gap in agricultural productivity and income (Udry, 1996; Fletschner, 2009, Zwarteveen, 1996), research on inequalities arising in the post-harvest period is relatively rare. Factors, such as information asymmetry (Fletschner \& Mesbah, 2011, Chowdury, 2006; Ngimwa et al., 1997), incomplete integration of farmers in high-value production and marketing chains could potentially affect farmers' intrahousehold bargaining by reducing the opportunities of better market access and higher income. So even if women have access to assets and control production, if they do not control the marketing of output, they may still have little control over the proceeds and thus lower household bargaining power. This could be particularly true for female farmers, who are typically less involved in commercialized farming due to lower adoption of new technologies, lower access to extension service, lower integration with marketing channels etc., which results in unequal market participation by them (e.g. Blackden \& Bhanu, 1999; Blackden et al. 2007; Kumase et al., 2008).

In our study we investigate female participation in commercialization of agricultural product and examine its impact on intrahousehold bargaining. The contribution of the study is threefold. Based on a survey with 911 male and female cocoa farmers in Cameroon, we first attempt to investigate the causes of unequal market participation by male and female farmers; second, we estimate the impact of market participation on intrahousehold bargaining; and third, we also explore the role of collective marketing in improving female market participation. Specific hypotheses that we examine are (1) market participation by female farmers is positively associated with collective marketing but negatively influenced by gender-based price discrimination in output markets (2) market participation affects control over cocoa revenue positively, where control over revenue is measured by the proportion of revenue controlled by the farmers individually.

Given that unobserved factors that explain female participation in marketing activities can be correlated with control over proceeds, simple OLS estimations would lead to biased results. We address this problem by linking the hypotheses above. In particular, our estimation uses the presence of collective marketing institutions (and male participation in these channels) as instruments for female market participation.

Cameroon's cocoa production provides us with a unique platform to address the research objective as, unlike in Asia, in many Sub-Saharan African countries, such as in Cameroon, 
agricultural production is often managed and controlled by male and female farmers separately. Decision-making authority with respect to the cultivation on these plots rests with individual household members; cultivation expenses are paid by the individual; and output from the plot is attributed to that individual (Duflo and Udry 2004, Bisseleua, Klasen, and Kumase, 2005). This enables us to investigate marketing activities and resulting income inequalities by gender of the farmer.

Our data shows that although female farmers manage cultivation individually, marketing of cocoa mostly rests in the hands of the men. In contrast, male farmers usually control both the production as well as the marketing of cocoa. An important point to note here is that for (mostly female) farmers who do not participate in marketing, our data show that the task is then mainly carried out by another (typically male) family member. We also find that one of the plausible factors that could explain the lower market participation by female farmers is price discrimination. In particular, female farmers who market their cocoa receive significantly lower prices than their male counterparts. Consequently, revenue received by participating women is much lower than by participating men indicating that income opportunities are higher if a man takes over the marketing task. In our research area, we therefore find a large number of women relying on male members of the family for marketing their produce. While this strategy leads to higher revenues for the household, we find that it lowers the share of resources controlled by women compared to the situation where female farmers carry out the marketing themselves. Finally, our estimation shows that villages with better access to collective marketing could bring down the gender disparity in market participation by lowering the existing price discrimination. In particular, if male farmers increase their participation in collective marketing, the price received is uniform across all group members, thus removing the gender gap in prices, which in turn encourages female farmers to take part in the marketing and improves their control over proceeds.

The paper is organized as follows. Section 2.2 provides a brief description of the study context and discusses the data; section 2.3 provides a description of the estimation strategy; section 2.4 discusses the results; and section 2.5 concludes the paper. 


\subsection{Study context}

\subsubsection{The cocoa market in Cameroon}

The organization of cocoa marketing in Cameroon is characterized by the interactions between licensed buyers, buying agents ${ }^{3}$, Common Initiative Groups (CIGs) ${ }^{4}$ (who often present themselves as producers' organizations) and producers' organizations (PO $)^{5}$. Activity wise the POs and CIGs do not differ much from each other. They are different to some extent with respect to their funding sources. Licensed buyers are mostly based in the cities and buy cocoa in large quantities. They purchase either directly from farmers or rely on buying agents, who collect cocoa from large numbers of smallholder farmers. Buying agents often have longstanding relationships with farmers and offer them pre-harvest financing for input purchases. At harvest, they collect cocoa at the farmgate and then resell it to the licensed buyers. Licensed buyers transport the cocoa in large quantities to the buying centers, where it is sold to the exporters. Producers can market their cocoa either individually or collectively through POs and CIGs. Cocoa cultivation in Cameroon is a small-scale business with plantations ranging between two to five hectares. Most farmers are members of CIGs or POs, even if they market their cocoa individually. As members of such groups they can leverage the benefits of collective action, in terms of easier access to fertilizers and pesticides, regular contacts to government extension officers and exchange of knowledge, and better marketing opportunities and prices.

In case of collective marketing, these groups sign contracts with buyers, identify those members who have cocoa for sale, and then sell the total amount of cocoa collectively to the buyer. Thus, in the case of collective sales, CIGs and POs act as procurement organizations for buyers (Folefack \& Gockowski, 2004; Gockowski, 2008). However, cocoa sales do not figure high on the priority list of all CIGs. Many CIGs instead focus on the protection of farmers' rights, on the organization of extension visits to obtain information on new farming

\footnotetext{
${ }^{3}$ Buying agents work for a licensed buyer and are paid on commission.

${ }^{4}$ After liberalization in 1994, the government withdrew all financial support and farmers found it difficult to procure fungicides and pesticides from private suppliers and as a result many of them started to look for alternative agricultural activities. Under such a scenario, the government and many non-governmental-organizations (NGOs) started to encourage cocoa farmers and traders to organize themselves in 'common initiative groups' (CIGs) to promote welfare through bulk marketing. The formation of CIGs helped to reduce transaction costs and as a result the prices paid to producers increased. In 1997, world cocoa prices started to recover from previous lows, thus bringing back many farmers to cocoa production (Duguma et al. 2001).

${ }^{5}$ After liberalization, in the Centre region the former state cooperatives disappeared. POs primarily grew up with the support from development projects such as the Sustainable Tree Crop Program based at the IITA. According to Folefack \& Gockowski (2004), 40\% of the cocoa producers in the Centre are members of a PO. In the Southwest, the former cooperatives (such as the Southwest Farmer Cooperative Union based in Kumba) were placed in the hands of CIGs. In the absence of projects supporting producers' initiatives, no POs have been able to emerge in the Southwest.
} 
techniques, and on the promotion of farmer-to-farmer assistance through the creation of farmers' networks. However, most of the smallholders living in remote villages are not well connected with the market and lack sufficient knowledge about market prices. As a result, farmers can be exploited by buying agents who tend to behave opportunistically by offering lower prices than the market price. In addition, farmers often obtain input credit from buyers to purchase fertilizers and pesticides during the production phase, which is then deducted from their cocoa deliveries at harvest. Due to their repayment obligations, farmers also face a lower bargaining position vis-à-vis the buyer in such a situation. In this context, collective sales organized through CIGs can improve the farmers bargaining situation vis-à-vis buying agents and thus protect them from opportunistic behavior.

Hence, collective sell through the reduction of transaction costs not only facilitates better access to marketing channels, but it also secures access to new technologies, and allows farmers to tap into high value markets (Stockbridge et al., 2003). Additionally, there is evidence that collective action can help smallholders to reduce barriers to entry into markets by improving their bargaining power with buyers and intermediaries (Thorp et al., 2005; Kherallah et al., 2002).

\subsubsection{Empirical data and descriptive statistics}

The empirical analysis is based on primary data, which was collected in six major cocoa producing subdivisions in Southwest and Center Cameroon, namely Ngomedzap, Boumyebel, Obala, Mbangassina, Bokito and Kumba (Kumase et al., 2008) ${ }^{6}$. The survey was conducted in October and November 2007 using a multi-stage random sampling approach. In the first stage, twelve communities were randomly selected within the six sub-divisions. Subsequently, within these twelve communities, 53 villages and 911 respondents were selected randomly. In total, 181 female farmers and 770 male farmers participated in the survey. All survey participants are members of Common Initiative Groups (CIGs). The villages are small (500 5000 inhabitants), yet, differ regarding their ethnic background and market orientation. Villages in Kumba and Mbangassina are mainly composed of migrants, who are more marketoriented and less concerned with land accumulation than their indigenous counterparts. Women in these communities are more engaged in commercial activities that require them to leave their homesteads. Villages in Bokito, Boumyebel, Ngomedzap and Obala are mainly composed of local people who are less market-oriented. Women in these communities are involved in small income-generating activities, but unlike the women in Kumba and

\footnotetext{
${ }^{6}$ The survey in Kumase et al. (2008) was generated with support from BMZ via GIZ.
} 
Mbangassina, they generally carry out their activities at home and generate considerably lower earnings.

Table 2.1 presents descriptive statistics of individual characteristics by gender. Results show that while overall $78 \%$ of the farmers in our sample are married, marriage rates are significantly higher for male farmers. This is due to the fact that many female farmers are either widowed or single women, which is part of the reason that they control cocoa production. Nonetheless, a considerable share of female farmers in our sample is married (37\%) and still controls cocoa production. Our data further suggest that female farmers are significantly less educated than male farmers: while $64 \%$ of men have completed primary education only $37 \%$ of women have done so. Moreover, our data confirm results found in other studies that women have substantially lower access to extension services. Interestingly, although significantly fewer women inherited the land they use, they hold more land titles than men. For many women in our sample, access to land has come as a result of land purchases, where titles are commonly awarded (Bisseleua, Klasen, and Kumase, 2008).

With respect to cocoa marketing, we find that $40 \%$ of female farmers in our sample are not marketing their cocoa themselves, whereas only $4 \%$ of the male farmers delegate the marketing to somebody else. Similarly, the average price received by cocoa producers varies significantly across gender. On average, male farmers receive $811 \mathrm{CFA}^{7}$ per kilogram of cocoa, whereas female farmers receive only $570 \mathrm{CFA}$. This provides some evidence that gender-related price discrimination exists in the Cameroonian cocoa market. Finally, control over income is measured as the share of the cocoa revenue controlled by the individual farmer. In the questionnaire, farmers were asked what proportion of the revenue they could dispose of. Results of a t-test on gender differences show that the average share of income controlled does not differ significantly between male and female farmers in our sample.

\footnotetext{
${ }^{7} \mathrm{CFA}$ is the currency of central and west Africa, which has been firmly linked to the French franc since 1948.
} 
Table 2.1: Descriptive statistics of individual characteristics by gender

\begin{tabular}{|c|c|c|c|c|}
\hline & \multicolumn{3}{|c|}{ Mean } & \multirow[b]{3}{*}{ t-stat } \\
\hline & & $(\mathrm{sd})$ & & \\
\hline & All & Female & Male & \\
\hline Share of revenue controlled & $\begin{array}{l}0.46 \\
(0.23)\end{array}$ & $\begin{array}{l}0.47 \\
(0.22)\end{array}$ & $\begin{array}{l}0.45 \\
(0.23)\end{array}$ & -0.76 \\
\hline Female & $\begin{array}{l}0.22 \\
(0.41)\end{array}$ & & & \\
\hline Participation & $\begin{array}{l}0.88 \\
(0.32)\end{array}$ & $\begin{array}{l}0.61 \\
(0.49)\end{array}$ & $\begin{array}{l}0.96 \\
(0.2)\end{array}$ & 16.10 \\
\hline Extension service & $\begin{array}{l}0.42 \\
(0.49)\end{array}$ & $\begin{array}{l}0.28 \\
(0.45)\end{array}$ & $\begin{array}{l}0.46 \\
(0.5)\end{array}$ & 5.04 \\
\hline Age of plant ( months) & $\begin{array}{l}41.30 \\
(2.78)\end{array}$ & $\begin{array}{l}35.88 \\
(1.44)\end{array}$ & $\begin{array}{l}42.82 \\
(3.53)\end{array}$ & 1.03 \\
\hline Age & $\begin{array}{l}49.58 \\
(12.83)\end{array}$ & $\begin{array}{l}50.3 \\
(10.97)\end{array}$ & $\begin{array}{l}49.39 \\
(13.32)\end{array}$ & -0.94 \\
\hline Household size & $\begin{array}{l}7.02 \\
(4.32)\end{array}$ & $\begin{array}{l}6.32 \\
(3.21)\end{array}$ & $\begin{array}{l}7.23 \\
(4.57)\end{array}$ & 2.81 \\
\hline Secondary and above & $\begin{array}{l}0.06 \\
(0.23)\end{array}$ & $\begin{array}{l}0.02 \\
(0.14)\end{array}$ & $\begin{array}{l}0.07 \\
(0.25)\end{array}$ & 2.53 \\
\hline Primary completed & $\begin{array}{l}0.58 \\
(0.49)\end{array}$ & $\begin{array}{l}0.37 \\
(0.48)\end{array}$ & $\begin{array}{l}0.64 \\
(0.48)\end{array}$ & 7.35 \\
\hline Less than primary & $\begin{array}{l}0.36 \\
(0.48)\end{array}$ & $\begin{array}{l}0.61 \\
(0.49)\end{array}$ & $\begin{array}{l}0.29 \\
(0.46)\end{array}$ & -8.88 \\
\hline Married & $\begin{array}{l}0.78 \\
(0.42)\end{array}$ & $\begin{array}{l}0.37 \\
(0.48)\end{array}$ & $\begin{array}{l}0.89 \\
(0.31)\end{array}$ & 19.18 \\
\hline Land title & $\begin{array}{l}0.16 \\
(0.37)\end{array}$ & $\begin{array}{l}0.26 \\
(0.44)\end{array}$ & $\begin{array}{l}0.13 \\
(0.34)\end{array}$ & -4.42 \\
\hline Non-farm activity & $\begin{array}{l}0.25 \\
(0.43)\end{array}$ & $\begin{array}{l}0.21 \\
(0.41)\end{array}$ & $\begin{array}{l}0.26 \\
(0.44)\end{array}$ & 1.63 \\
\hline Cocoa area & $\begin{array}{l}4.84 \\
(5.19)\end{array}$ & $\begin{array}{c}4.52 \\
(5.04)\end{array}$ & $\begin{array}{l}4.94 \\
(5.24)\end{array}$ & 1.05 \\
\hline Age of cocoa plant(months) & $\begin{array}{l}41.30 \\
(2.78)\end{array}$ & $\begin{array}{l}35.88 \\
(1.44)\end{array}$ & $\begin{array}{l}42.82 \\
(3.53)\end{array}$ & 1.03 \\
\hline Price & $\begin{array}{l}757.93 \\
(30.02)\end{array}$ & $\begin{array}{l}570.44 \\
(30.86)\end{array}$ & $\begin{array}{l}811.06 \\
(37.30)\end{array}$ & 3.34 \\
\hline Female to male average price ration in village & $\begin{array}{l}0.92 \\
(0.57)\end{array}$ & & & \\
\hline Marketing through CIG & $\begin{array}{l}0.27 \\
(0.44)\end{array}$ & $\begin{array}{l}0.23 \\
(0.42)\end{array}$ & $\begin{array}{l}0.28 \\
(0.45)\end{array}$ & 1.43 \\
\hline
\end{tabular}

Table 2.2 reports the share of revenue controlled by market participation status and gender. We find that farmers, who market their cocoa, in general have slightly higher control over the proceeds from cocoa marketing; however, the difference between market participants and non-participants is not statistically significant. Yet, in the case of female farmers the control 
over revenue is significantly higher in the case of market participation. This indicates that for female farmers, market participation is positively associated with their intra-household bargaining power providing evidence in support of our hypothesis that market participation renders higher control over proceeds.

Table 2.2: Share of revenue controlled by market participation and gender

\begin{tabular}{lccccc}
\hline & All & Participants & $\begin{array}{l}\text { Non- } \\
\text { participants }\end{array}$ & Participants - Non-participants t-stat \\
\hline \hline All & 0.46 & 0.46 & 0.44 & 0.02 & 1.08 \\
Male & $(0.01)$ & $(0.02)$ & $(0.01)$ & $(0.02)$ & 0.56 \\
& 0.45 & 0.45 & 0.43 & 0.02 & \\
Female & $(0.01)$ & $(0.01)$ & $(0.03)$ & $0.04)$ & $\mathbf{1 . 6 4}$ \\
& 0.47 & 0.48 & 0.44 & $(0.03)$ & \\
\hline
\end{tabular}

Note: Standard errors are reported in the parentheses.

Table 2.3 presents further evidence on price discrimination in cocoa markets and how collective marketing relates to such discrimination.

Table 2.3: Prices received by gender

\begin{tabular}{|c|c|c|c|}
\hline & Male & Female & t-stat \\
\hline All & $\begin{array}{l}811.06 \\
(37.30)\end{array}$ & $\begin{array}{l}570.44 \\
(30.86)\end{array}$ & (3.34 \\
\hline Participants & $\begin{array}{l}813.82 \\
(38.20)\end{array}$ & $\begin{array}{l}526.51 \\
(15.00)\end{array}$ & 3.13 \\
\hline Non-participants & $\begin{array}{l}760.66 \\
(207.44)\end{array}$ & $\begin{array}{l}624.74 \\
(77.69)\end{array}$ & 0.75 \\
\hline t-stat & 0.27 & 1.51 & \\
\hline Selling through CIG & $\begin{array}{l}682.38 \\
(60.2)\end{array}$ & $\begin{array}{l}584.92 \\
(39.89)\end{array}$ & 0.76 \\
\hline Not selling through CIG & $\begin{array}{l}862.7 \\
(46.71)\end{array}$ & $\begin{array}{l}556.48 \\
(40.05)\end{array}$ & 3.43 \\
\hline t-stat & 2.16 & 0.37 & \\
\hline Participants selling through CIG & $\begin{array}{l}682.07 \\
(61.26)\end{array}$ & $\begin{array}{l}538.64 \\
(17.11)\end{array}$ & 0.73 \\
\hline Participants not selling through CIG & $\begin{array}{l}867.64 \\
(47.53)\end{array}$ & $\begin{array}{l}522.02 \\
(17.68)\end{array}$ & 3.27 \\
\hline Non-Participants, selling through CIG & $\begin{array}{l}699.44 \\
(122.33)\end{array}$ & $\begin{array}{l}620.03 \\
(68.77)\end{array}$ & 0.41 \\
\hline Non-participants, not selling through CIG & $\begin{array}{l}770.29 \\
(255.68)\end{array}$ & $\begin{array}{l}624.79 \\
(114.34)\end{array}$ & 0.6 \\
\hline Villages without male farmers selling through CIG* & $\begin{array}{l}1098.91 \\
(82.71)\end{array}$ & $\begin{array}{l}627.57 \\
(86.21)\end{array}$ & 2.78 \\
\hline Villages with male farmers selling through CIG & $\begin{array}{l}644.23 \\
(32.09)\end{array}$ & $\begin{array}{l}542.65 \\
(17.77)\end{array}$ & 1.63 \\
\hline
\end{tabular}

Note: Standard errors are reported in the parentheses, *these are villages where either no farmer or only female farmers participate in collective marketing. In our sample, $34 \%$ of the villages reported no male participation in collective marketing, whereas $33 \%$ of the villages are without any collective marketing. Gender differences in received prices in villages where no farmer is involved in collective marketing are also highly significant (at less than $1 \%$ ). 
The results allow us to make four distinct observations. First, irrespective of the marketing channel and farmers' market participation status, female farmers receive significantly lower prices than male farmers on average. Second, price discrimination occurs when female farmers are doing their own marketing; if they rely on others to do the marketing; they receive better prices, but still not the prices that are as high as those of male participants. Compared to the few male non-participants, however, the price differences are insignificant. Third, such discrimination is absent in collective sales, even if the female farmer is choosing to participate in marketing; conversely, gender-specific price discrimination is largest in the case of individual marketing. Fourth, in regions where males do not participate in collective marketing, the gender gap in prices is significant whereas in regions where male do take part, this gap becomes insignificant.

\subsection{Estimation strategy}

This section provides details on our estimation strategy identifying the determinants of market participation and the impact of market participation on control over cocoa proceeds. Hence we are interested in estimating the following model:

$S_{i j}=\alpha_{0}+\alpha_{1} P_{i j}+\alpha_{2} X_{i j}+e_{i j} \ldots(1)$

Where $\mathrm{S}_{\mathrm{ij}}$ is the share of revenue controlled by farmer $i$ in village $j ; \mathrm{P}$ is the market participation dummy and $\mathrm{X}$ is a set of exogenous variables. The $\alpha$ 's are the parameters to be estimated; and e is unobserved error terms.

OLS estimates of the parameters in equation (1) are likely to be bias. In particular, female farmers may self-select out of market participation because of factors such as lower negotiation skills, lack of sufficient information, lower bargaining power, etc. (Fletschner \& Mesbah, 2011, Chowdury, 2006; Ngimwa et al., 1997). If those unobserved variables correlate positively with control over revenues as well as with the market participation decision, OLS estimates of $\alpha_{1}$ in equation (1) are biased upward, since part of the estimated effect of participation on control over proceeds can be attributed to female bargaining. Therefore, we need to account for potential endogeneity (from omitted variable bias and selection bias) using instrumental variables.

\subsubsection{Identification}

We use the percentage of male farmers in a village who sell collectively through CIGs as well as its interaction with gender as instruments in our analysis. We base our IV on the hypothesis that the higher the proportion of male farmers involved in collective marketing, the lower the 
gender-specific price discrimination in the village, which then would promote female market participation.

The data presented in Table 2.3 show that price discrimination in our set up arises when male farmers sell individually and thus receive higher prices than women. Consequently, a female farmer might decide not to engage in marketing (either individually or collectively), but rather rely on a male family member to carry out the task. As shown in Table 2.3, however, in villages where male farmers participate in collective marketing, the prices received are similar for both men and women. Accordingly, as shown in Table 2.4 below, women are more likely to participate in marketing in these villages.

By linking collective marketing to the likelihood of female market participation, we are able to test for the effect of market participation on the share of cocoa revenue controlled by the farmer.

The model that considers potential endogeneity of female market participation can be specified as the following two stage model.

$S_{i j}=\alpha_{0}+\alpha_{1} P_{i j}+\alpha_{2} X_{i j}++v_{j}+e_{i j} \ldots(1)$

First Stage:

$P_{i j}=\beta_{0}+\beta_{1} z_{i j}+\beta_{2} X_{i j}+v_{j}+n_{i t} \ldots .(2)$

Second Stage:

$S_{i j}=\alpha_{0}+\alpha_{1} \hat{P}_{i j}+\alpha_{2} X_{i j}++v_{j}+e_{i j} \ldots(1)$

where $\hat{P}$ is the estimated market participation dummy $\mathrm{v}_{\mathrm{j}}$ are village fixed effects $\mathrm{z}$ is our instrument, and $\beta$ 's are parameters to be estimated; and $n$ are random error terms. In the following section we discuss the endogeneity issue and the identification strategy used in our analysis.

One potential concern here is that it is possible that female farmers are receiving lower price because of differences in quality. Our data does not provide us the scope to test for such differences. However, if this is one factor causing differences in price received by male and female farmers, such differences should exists even among those who sells collectively and among the non-market participants. Instead, we observe significant difference only for females who are participating in marketing and choosing to sell individually, which is a strong indication of price discrimination due to gender discrimination, not due to quality differences. 
However, to control for cocoa quality we use age of cocoa plant (in moths) to control for quality of cocoa (Dada, 2007).

Another issue is that it appears that men are losing out by choosing to market their produce collectively; as shown in Table 2.3, they receive lower prices when selling through CIGs. So why are they still choosing to participate in collective marketing? Two factors may play a role. One is that participation in collective marketing generates other benefits of a more active CIG that makes it attractive for male farmers to participate. This could include more stable prices, better access to inputs and credit, access to subsidized services, and the like. Second, there might be self-selection issues with more assertive males choosing to market individually, while others rely on collective marketing. It is beyond the scope of this paper to investigate these interesting issues in more detail. Nonetheless, neither of these factors would adversely affect the relevance of this variable as an instrument for female participation, the focus of our study.

Table 2.4: Market participation in villages with and without male farmers selling through CIGs

\begin{tabular}{lccc}
\hline & All & Male & Female \\
\hline Villages without male farmers selling through CIG & 0.86 & 0.94 & 0.52 \\
& $(0.02)$ & $(0.01)$ & $(0.05)$ \\
Villages with male farmers selling through CIG & 0.9 & 0.97 & 0.65 \\
& $(0.01)$ & $(0.01)$ & $(0.04)$ \\
\hline t-stat & $\mathbf{- 1 . 9}$ & -1.26 & $\mathbf{- 1 . 9 6}$ \\
\hline
\end{tabular}

Note: Standard errors are reported in the parentheses

\subsubsection{Exogeneity of instrument}

Regarding exogeneity of the instrument, we suggest that this (village-level) aggregate measure is unlikely to have a direct influence on the share of female proceeds other than through the impact it has on the likelihood of female participation in the marketing chain. In order to test the exclusion restriction we regress the instrument on the share of cocoa revenue controlled by the farmer. Exogeneity of the instrument would imply that the instrument should not have any significant impact on share of revenue controlled by the farmer. In Table A1 (see appendix) we show the exogeneity condition and the models estimated show that percentage of male farmers selling collectively and its interaction with female dummy are appearing with insignificant coefficient, thereby, supporting our suggestion that the instrument is exogenous. 


\subsection{Results}

\subsubsection{Market participation}

Table 2.5 Regressing market participation on a set of exogenous controls, we find that female farmers are significantly less likely to participate in cocoa marketing (see Model1). Compared to male farmers, female farmers have a $32 \%$ lower probability to participate in markets. Furthermore, the coefficients on age and age squared are statistically significant indicating that participation increases with age, albeit at a decreasing rate. We also find evidence that higher education is critical for market participation. Compared to farmers with lower education (less than primary or no education at all is the left-out category), farmers who completed secondary education have $8 \%$ higher probability to participate in the market.

In Model 2, we include our main identification variable percentage of male farmers selling through CIGs in village along with additional controls: age of cocoa plant in months and interactions of female dummy with land title and marriage dummy. As per our expectation the identification variables appears with a significant and positive coefficient. Age variable loses its significance, but age square still has a negative impact and higher education still exerts similar impact on participation. Additionally we find that married women are likely to participate less than the unmarried women.

In Model 3 includes all the controls in Model 2 and additionally it controls for female to male average price ratio in village. When including these additional variables, results on female dummy, higher education and age remain robust across all the three model specifications. However, we find that after including price ratio as additional regressor, our identification variable, percentage of male farmers selling through CIG, again appears with a significant and positive coefficient, but compared with Model 2 size of its coefficient decreases significantly (at less than 5\% level). On the other hand, price ratio influences participation significantly and positively with its impact being $4 \%$. Thus, as the prices received by female farmers increase relative to that received by men (and thus price discrimination against female farmers decreases) female market participation is promoted. 
Table 2.5: Determinants of market participation

\begin{tabular}{|c|c|c|c|}
\hline Dependent variable: Market Participation dummy & Model1 & Model2 & Model3 \\
\hline \multirow[t]{2}{*}{$\%$ of male farmers selling collectively in village } & & $1.008 * * *$ & $0.624 * * *$ \\
\hline & & $(0.053)$ & $(0.077)$ \\
\hline \multirow[t]{2}{*}{ Female to male average price ratio in village } & & & $0.043 * * *$ \\
\hline & & & $(0.012)$ \\
\hline \multirow[t]{2}{*}{ Female } & $-0.329 * * *$ & $-0.223^{* * *}$ & $-0.249 * * *$ \\
\hline & $(0.068)$ & $(0.083)$ & $(0.081)$ \\
\hline \multirow[t]{2}{*}{ Age } & $0.011^{*}$ & 0.008 & $0.010^{*}$ \\
\hline & $(0.006)$ & $(0.005)$ & $(0.006)$ \\
\hline \multirow[t]{2}{*}{ Age sq. } & $-0.011 *$ & $-0.009^{*}$ & $-0.012 *$ \\
\hline & $(0.006)$ & $(0.005)$ & $(0.006)$ \\
\hline \multirow[t]{2}{*}{ Household size } & 0.004 & 0.004 & 0.004 \\
\hline & $(0.002)$ & $(0.002)$ & $(0.003)$ \\
\hline \multirow[t]{2}{*}{ Married } & -0.061 & 0.008 & -0.021 \\
\hline & $(0.049)$ & $(0.039)$ & $(0.038)$ \\
\hline \multirow[t]{2}{*}{ Primary completed } & 0.040 & 0.035 & 0.030 \\
\hline & $(0.025)$ & $(0.025)$ & $(0.026)$ \\
\hline \multirow[t]{2}{*}{ Secondary and above } & $0.088^{* *}$ & $0.080^{* *}$ & $0.076^{*}$ \\
\hline & $(0.038)$ & $(0.036)$ & $(0.038)$ \\
\hline \multirow[t]{2}{*}{ Land title } & -0.041 & -0.036 & -0.041 \\
\hline & $(0.036)$ & $(0.036)$ & $(0.041)$ \\
\hline \multirow[t]{2}{*}{ Cocoa area } & 0.770 & 0.642 & 2.175 \\
\hline & $(2.876)$ & $(2.866)$ & $(2.741)$ \\
\hline \multirow[t]{2}{*}{ Non-farm activity } & -0.011 & -0.008 & -0.004 \\
\hline & $(0.027)$ & $(0.026)$ & $(0.026)$ \\
\hline \multirow[t]{2}{*}{ Extension service } & 0.004 & 0.009 & 0.006 \\
\hline & $(0.019)$ & $(0.020)$ & $(0.022)$ \\
\hline \multirow[t]{2}{*}{ Age of cocoa plant(months) } & & $-2.6 \mathrm{E}-05$ & $-1.7 \mathrm{E}-05$ \\
\hline & & $(5.7 \mathrm{E}-05)$ & $(4.8 \mathrm{E}-050)$ \\
\hline \multirow[t]{2}{*}{ Land title*Female } & & -0.019 & -0.014 \\
\hline & & $(0.101)$ & $(0.101)$ \\
\hline \multirow[t]{2}{*}{ Married*Female } & & $-0.198^{*}$ & -0.170 \\
\hline & & $(0.110)$ & $(0.105)$ \\
\hline \multirow[t]{2}{*}{ Constant } & -0.094 & -0.177 & $0.311^{*}$ \\
\hline & $(0.103)$ & $(0.122)$ & $(0.165)$ \\
\hline Observations & 911 & 911 & 780 \\
\hline
\end{tabular}

Note: Robust standard errors in parentheses; $* * * \mathrm{p}<0.01, * * \mathrm{p}<0.05, * \mathrm{p}<0.1$; for education the left-out category is less than primary education; village fixed effects are included in all models. In Model 3 sample size is reduced because there are some villages without any female respondent. 
Since, after including price ratio as a regressor, coefficient on the identification variable falls in magnitude significantly, one could also see this as a transmission channel through which the identification variable is affecting participation ${ }^{8}$.

\subsubsection{Control over revenue}

Table 2.6 provides the estimation results from the instrumental variable analysis of control over cocoa revenue treating market participation choice as endogenous regressor.

Similar to Table 2.4 and 2.5 the basic model we use for our analysis is Model 1 with covariates female dummy (which takes the value 1 if the producer is female), age variables, household size, marriage dummy, primary and higher education dummies, land title dummy, area of cocoa cultivated, non-farm activity dummy and access to extension service dummy. To this basic model we added and subtracted other covariates and produce estimation results for various other model specifications. Model 2 also includes interactions of female dummy with land title dummy and marriage dummy. Model 3 excludes extension service from Model 1. Model 4 includes interaction between female dummy and participation. In addition it also includes age of cocoa plant and subtracts age square, marriage dummy and non-farm activity from Model 1. Finally Model 5 includes all covariates of Model 1 and 4. Hence, the first three models in Table 2.6 report the estimation results of the impact of market participation on control over cocoa revenue and last two models additionally estimates differences in impacts of market participation by gender.

Model 1, 2 and 3 show positive and significant impacts of participation on farmers' control over the proceeds and the magnitude of impact varies in a range from $50 \%$ to $58 \%$. The female dummy has a positive and significant coefficient in Model 1 and 3. This suggests that female producers tend to have a higher control over proceeds, controlling for the all covariates including participation. However, when the female dummy is interacted with land title and marriage dummies (see Model 2) the significance of female dummy disappears and coefficient of female and married dummy appears with significantly positive impact; this suggests that married female producers can claim a higher share. Quantitatively, it indicates that marriage provides $16 \%$ higher control over revenue to women than to men. The marriage dummy has no significant coefficient indicating that marital status does not have a significant impact on control over revenues by men. Furthermore, estimating the impact of marriage for

\footnotetext{
${ }^{8}$ To test for the impact of male participation in collective marketing on village price discrimination we ran a separate regression with price ratio as a dependent variable and our instrument, percentage of male selling through collective marketing, as an independent variable along with other controls in Model2. The instrument is found to improve discrimination significantly (at less than $1 \%$ level) by $40 \%$.
} 
all farmers (joint effect of marriage and the interaction between female and marriage dummies) we find that marriage increases the share of revenues controlled by $11 \%$ (significant at 5\%). Additionally, we find that in all three models holding a land title increases control over revenue by $4 \%$ to $5 \%$, indicating that land rights provide higher control over revenue and thus also provides higher bargaining power.

In Model 4 and 5 we include an interaction term between market participation and gender and age of the cocoa plant. In Model 4 we find that by female farmers who participate in the market control significantly higher proportion of the cocoa revenue. In Model 5, the interaction term has the nearly the identical quantitative magnitude but just misses significance, presumably doe to correlations with the additionally included covariates. In both models, the coefficient of participation is positive but insignificant indicating that participation does not have significant impact on male control over cocoa proceeds. Considering the joint impact of participation and its interaction with female dummy we find positive and significant (at 1\% and 5\% level, respectively) impact of participation on control over revenue in both models. Additionally in Model 4 extension service exerts a positive and significant impact by increasing farmers' control over revenue by $11 \%$.

Looking at the instruments we find that percentage of male farmers selling collectively in village has strong positive impact on participation (see Table A2 in the appendix in which we reported the first stage regression results of models estimated in Table 2.6) . In Model 4 and 5, we additionally included interaction of the instrument and female dummy to control for the endogeneity of interaction of participation and female dummy. In models where participation is included as endogenous regressor percentage of male farmers selling through CIGs is included as IV and models that additionally interacts female dummy with participation utilizes IV interacted with female dummy as the IV. Therefore, all our models are exactly identified. The first stage results shows that the interaction of our main instrument and female dummy has a significant but negative impact on participation in both specifications, implying that in general the instrument has a positive impact on participation, however its impact on female farmers participation is less than that on male farmers. However, it does not affect interactions of participation and female dummy significantly indicating that it is not a strong instrument for this interaction, so that identification relies largely on the other instrument. 
Table 2.6: Instrumental variable analysis of control over cocoa revenue

\begin{tabular}{|c|c|c|c|c|c|}
\hline Dependent variable: Share of cocoa revenue & Model1 & Model2 & Model3 & Model4 & Model5 \\
\hline Participation & $\begin{array}{c}0.560^{* * *} \\
(0.235)\end{array}$ & $\begin{array}{c}0.504^{* *} \\
(0.229)\end{array}$ & $\begin{array}{c}0.586 * * * \\
(0.192)\end{array}$ & $\begin{array}{l}-6.429 \\
(4.252)\end{array}$ & $\begin{array}{l}-6.890 \\
(4.677)\end{array}$ \\
\hline Participation*Female & & & & $\begin{array}{l}7.548^{*} \\
(4.414)\end{array}$ & $\begin{array}{c}7.834 \\
(4.906)\end{array}$ \\
\hline Female & $\begin{array}{c}0.173 * * \\
(0.088)\end{array}$ & $\begin{array}{c}0.064 \\
(0.082)\end{array}$ & $\begin{array}{c}0.183 * * \\
(0.076)\end{array}$ & $\begin{array}{l}-6.858^{*} \\
(4.160)\end{array}$ & $\begin{array}{l}-7.110 \\
(4.623)\end{array}$ \\
\hline Age & $\begin{array}{l}-0.005 \\
(0.004)\end{array}$ & $\begin{array}{l}-0.002 \\
(0.004)\end{array}$ & $\begin{array}{l}-0.005 \\
(0.004)\end{array}$ & $\begin{array}{l}-0.005 \\
(0.005)\end{array}$ & $\begin{array}{l}-0.006 \\
(0.006)\end{array}$ \\
\hline Age sq. & $\begin{array}{c}4.0 \mathrm{E}-05 \\
(3.0 \mathrm{E}-05)\end{array}$ & $\begin{array}{c}4.0 \mathrm{E}-05 \\
(3.0 \mathrm{E} 05)\end{array}$ & $\begin{array}{l}4.0 \mathrm{E}-05 \\
(3.0 \mathrm{E}-05)\end{array}$ & & \\
\hline Household size & $\begin{array}{l}-0.002 \\
(0.002)\end{array}$ & $\begin{array}{l}-0.001 \\
(0.002)\end{array}$ & $\begin{array}{l}-0.002 \\
(0.003)\end{array}$ & $\begin{array}{c}0.003 \\
(0.009)\end{array}$ & $\begin{array}{c}0.003 \\
(0.012)\end{array}$ \\
\hline Married & $\begin{array}{c}0.012 \\
(0.035)\end{array}$ & $\begin{array}{l}-0.050 \\
(0.033)\end{array}$ & $\begin{array}{c}0.012 \\
(0.036)\end{array}$ & & $\begin{array}{c}0.129 \\
(0.128)\end{array}$ \\
\hline Primary completed & $\begin{array}{c}0.001 \\
(0.015)\end{array}$ & $\begin{array}{c}0.007 \\
(0.013)\end{array}$ & $\begin{array}{l}-0.001 \\
(0.016)\end{array}$ & $\begin{array}{c}0.080 \\
(0.107)\end{array}$ & $\begin{array}{c}0.092 \\
(0.112)\end{array}$ \\
\hline Secondary and above & $\begin{array}{l}-0.058^{*} \\
(0.032)\end{array}$ & $\begin{array}{l}-0.046 \\
(0.029)\end{array}$ & $\begin{array}{l}-0.060 * \\
(0.035)\end{array}$ & $\begin{array}{c}0.286 \\
(0.231)\end{array}$ & $\begin{array}{c}0.372 \\
(0.280)\end{array}$ \\
\hline Land title & $\begin{array}{c}0.051 * * * \\
(0.020)\end{array}$ & $\begin{array}{c}0.040 * * \\
(0.019)\end{array}$ & $\begin{array}{l}0.051^{* *} \\
(0.020)\end{array}$ & $\begin{array}{l}-0.106 \\
(0.176)\end{array}$ & $\begin{array}{l}-0.121 \\
(0.194)\end{array}$ \\
\hline Cocoa area & $\begin{array}{l}-4.0 \mathrm{E}-04 \\
(0.002)\end{array}$ & $\begin{array}{c}-2.0 \mathrm{E}-04 \\
(0.002)\end{array}$ & $\begin{array}{c}-4.6 \mathrm{E}-05 \\
(0.002)\end{array}$ & $\begin{array}{l}-0.003 \\
(0.010)\end{array}$ & $\begin{array}{l}-0.004 \\
(0.011)\end{array}$ \\
\hline Non-farm activity & $\begin{array}{l}-0.005 \\
(0.020)\end{array}$ & $\begin{array}{l}-0.009 \\
(0.018)\end{array}$ & $\begin{array}{l}-0.005 \\
(0.020)\end{array}$ & & $\begin{array}{l}-0.115 \\
(0.147)\end{array}$ \\
\hline Extension service & $\begin{array}{l}-0.007 \\
(0.021)\end{array}$ & $\begin{array}{l}-0.011 \\
(0.021)\end{array}$ & & $\begin{array}{l}0.114 * \\
(0.058)\end{array}$ & $\begin{array}{c}0.110 \\
(0.082)\end{array}$ \\
\hline Age of cocoa plant(months) & & & & $\begin{array}{c}-4.6 \mathrm{E}-05 \\
(2.0 \mathrm{E}-04)\end{array}$ & $\begin{array}{l}-6.1 \mathrm{E}-05 \\
(2.0 \mathrm{E}-04)\end{array}$ \\
\hline land title*Female & & $\begin{array}{l}0.028 \\
(0.048)\end{array}$ & & & \\
\hline Married*Female & & $\begin{array}{c}0.165 * * * \\
(0.061)\end{array}$ & & & \\
\hline Constant & $\begin{array}{c}0.034 \\
(0.257)\end{array}$ & $\begin{array}{c}0.076 \\
(0.251)\end{array}$ & $\begin{array}{c}0.018 \\
(0.236)\end{array}$ & $\begin{array}{c}0.018 \\
(0.236)\end{array}$ & $\begin{array}{c}7.097 \\
(4.663)\end{array}$ \\
\hline Observations & 911 & 911 & 911 & 911 & 911 \\
\hline \multicolumn{6}{|l|}{ Excluded instruments } \\
\hline $\begin{array}{l}\% \text { of male farmers selling collectively } \\
\% \text { of male farmers selling collectively }\end{array}$ & $\begin{array}{l}\text { Yes } \\
\text { No }\end{array}$ & $\begin{array}{l}\text { Yes } \\
\text { No }\end{array}$ & $\begin{array}{l}\text { Yes } \\
\text { No }\end{array}$ & $\begin{array}{l}\text { Yes } \\
\text { Yes }\end{array}$ & $\begin{array}{l}\text { Yes } \\
\text { Yes }\end{array}$ \\
\hline \multicolumn{6}{|l|}{ F-stat of excluded instruments } \\
\hline $\begin{array}{l}\text { Participation } \\
\text { Participation*Female }\end{array}$ & 15.92 & 17.22 & 18.43 & $\begin{array}{l}5.09 \\
8.34\end{array}$ & $\begin{array}{l}6.68 \\
11.5 \\
\end{array}$ \\
\hline
\end{tabular}

Note: Robust standard errors in parentheses; $* * * \mathrm{p}<0.01, * * \mathrm{p}<0.05, * \mathrm{p}<0.1$; for education the left-out category is less than primary education; village fixed effects are included in all models; First stage results are reported in the appendix. For participation*Female we use \% of male farmers selling collectively in village*Female as instrument. Result of the first stage regressions in shown in Table 2.8 in the Appendix. 
Additionally, in Table A2 we report the test results of endogeneity of participation choices using Durbin-Wu-Hausman chi-sq test. Under the null hypothesis that participation is exogenous, these statistics are all significant indicating endogeneity of participation.

\subsection{Conclusion}

This paper examines participation of female farmers in agricultural marketing and its impact on control over revenues. Using data micro level data from Cameroon's cocoa producers in our study we measure commercialization of farmers by their integration with cocoa markets and argue that by participating in cocoa marketing farmers; especially the female farmers who generally participate less in marketing; could increase their intrahousehold welfare. Our data shows that a female farmers, individually, are managing their cocoa production which is a major cash crop of the country (Duguma and Gockowski, 2001), but very few of them take up the marketing activities. In other words, while male farmers are producing as well as marketing their own produce, female farmers participate only in production and not in marketing. Consequently, family members who help her in marketing could then claim a share in the revenue, reducing her own control over the sharing decision. Therefore, we argue that market participation provides higher bargaining power in deciding the sharing decision and provides higher control over the proceeds.

In our analysis we identify price discrimination against female farmers as a factor explaining significant gap in male and female market participation in cocoa markets in Cameroon. We make the argument that lower male participation in collective marketing leads to significant price discrimination against female farmers which then discourage female market participation. Essentially, such discrimination occurs because men with better marketing abilities despite their membership with CIGs decide to sell individually which then creates significant price gap between farmers selling individually and collectively. We do not find similar evidence for female farmers: female farmers do not gain significantly by selling individually. There could be various reasons for such different price attainments, such as, asymmetric information on market price, lower negotiation skill of female farmers, lower network opportunities etc. However these factors are all beyond the scope of our study. We precisely make the argument that our data shows evidence on gender discrimination in price received by cocoa farmers lowering their market participation.

We further argue that price discrimination is likely to be lower in regions where male participation in collective marketing is higher than those regions with lower male participation. As a result lower price discrimination will motivate more women to take up 
their own marketing. Therefore, in the estimation of impact of market participation on share of cocoa revenue controlled by farmer herself we use proportion of male farmers selling collectively in village for instrumenting market participation. This instrument satisfies the exogeneity condition of instrument as in a household model, extra-household factors, such as, male participation in collective marketing in any region, is likely to vary exogenously. Our estimation results confirm that the instrument has a significantly positive impact on market participation and market participation influences control over revenue positively. Therefore, our study establishes three major conclusions: price discrimination has been inhibiting female market participation; second, higher male participation in collective marketing reduces price discrimination and positively impacts on female market participation and finally, by participating in marketing female farmers could achieve higher control over cocoa revenue. 


\title{
3. Running for leadership: evidence from an artefactual field experiment in matrilineal and patriarchic societies in India ${ }^{9}$
}

\begin{abstract}
This paper investigates the process of gender self-segregation into leadership roles that imply control over others. We consider how conformity to social norms and aversion to feedback affect self-selection. Using a public good game with third party punishment we explore gender differences in willingness to assume the role of third party across matrilineal and patriarchal societies. Our findings indicate that segregation into leadership roles is due to conformity to pre-assigned gender roles across cultures. We find that women in the matrilineal society are more willing to assume power roles than in the patriarchal society. Moreover, we find that anonymity over the role of third party results in increase participation of the segregated gender. Affirmative action seems to be an is effective tool to promoting female leaders in societies where women hold a lower status; yet in societies where women are powerful the effect can be counterproductive.
\end{abstract}

Keywords: Gender and leadership, patriarchal and matrilineal societies, affirmative action, aversion to feedback, aversion to public roles, public good experiment with punishment

JEL Code: C90, C92, C93, C92, D03, D70, D81, J16

\footnotetext{
${ }^{9}$ This paper is a joint work with Marcela Ibanez, Gerhard Reiner and Meike Wollni. Ibanez: CRC Poverty Equity and Growth, University of Göttingen, Germany; Riener: Düsseldorf Institute for Competition Economics, University of Düsseldorf, Germany; Wollni: Department of Agricultural Economics and Rural Development, University of Göttingen, Germany
} 


\subsection{Introduction}

The enforcement of social norms is an important factor in the success of mankind (Fehr and Gächter, 2002; Fehr and Fischbacher, 2004). Social sanctions are used in many societies around the globe to overcome the problem of free-riding (Henrich et al., 2006). However, it remains unclear who is willing take up the role of norm enforcer and why. In many societies these roles are taken mainly by men, while women remain underrepresented in positions that imply control over others (Chattopadhyay and Duflo, 2004; Pande, 2003; Svaleryd, 2002; Thomas and Welch, 1991). In the United States, women comprise 29 percent of all lawyers, but represent only 16 percent of district judges, 17 percent of circuit court judges and 11 percent of Supreme Court posts (ABA, 2003; Federal Judicial Center, 2003). In other regions of the world female under representation is even larger. In Japan the share of female judges is below 10\% (Ministry of Justice, 2001). This is important from an efficiency perspective as greater gender diversity in leadership roles has shown to be beneficial in a variety of ways. It can increase confidence in the legal system (Brown, 1998); it can improve decisions making for deprived populations (Hurwitz and Lanier, 2008) and it can be vital to provide equal justice for all (Torres-Spelliscy et al., 2008).

The aim of this study is to investigate mechanisms underlying female under representation in the role of norm enforcers. In our analysis, we depart from traditional explanations based on discrimination on the installment process of judges. Instead, we consider that social orders emerge endogenously and investigate gender differences in willingness to volunteer to take the role of norm enforcer. Since the enforcement of social norms is one of the most important roles of a leader our finding can be generalized to the literature on leadership. In our set-up, norm enforcers act as leaders that have authority over others and can impose sanctions to discipline members of the society. Yet, norm enforcers have no strategic interest in enforcing social norms and sanctioning behavior is associated with normative principles.

Using the framework of a one-shot public good game with endogenous third party punishment, we compare the proportion of male and female participants who are willing to assume the role of third-party under different environments that vary: (i) the degree of counter-punishment or retaliation available, (ii) the degree of anonymity of the third-party and the (iii) societal background. We select these institutions as the psychology literature reports that women tend to incorporate negative feedback more than men (Roberts and NolenHoeksema, 1989). Women also tend to fall more often into confidence traps (Dweck, 2000), viewing negative feedback as indicative of their overall capability rather than simply their 
one-time performance on a task. ${ }^{10}$ If this is the case, environments that decrease feedback or counter punishment would foster female applications to leadership roles. Our second treatment investigates whether norms that prescribe that certain positions are to be assumed by a specific gender lead to the persistence of gender inequalities. So we consider whether reputation concerns versus altruistic concerns affect self-selection into leadership roles. Our last treatment considers the effect of the cultural background versus the effect of innate gender differences on the disposition to assume roles of control. We consider whether gender differences in role selection are due to nature or nurture. We therefore implemented the experiments in two different societies in India and compare the patriarchal Santal tribe, where women assume a more submissive role with the matrilineal Khasi tribe where women are in charge of decision making in and out-side the household.

From a policy perspective it is important to understand how to promote gender diversity in leadership positions. Therefore, in the experiment we additionally test two alternative policies that may influence the willingness to run for leadership. We test the effect of policies that provide economic incentives and give higher remuneration to leadership roles and policies that use affirmative action by giving preferential treatment to women willing to assume the leadership role.

We contribute to existing research in several ways. First we consider how leaders can affect the performance of the organization. In the economic literature, it is considered that leaders can help to overcome problems of asymmetric information by signaling the advantages of cooperation (Hermalin, 1998) either by leading by example (Clark and Sefton, 2001; Meidinger et al., 2003; Moxnes and Van der Heijden, 2003; Potters et al., 2005; 2007) or leading by sacrifice (De Cremer and van Knippenberg, 2005; Glöckner et al., 2011). Leaders can also help to overcome coordination problems by taking initiative and setting an example (Brandts and Cooper, 2006; 2007). Alternatively, leaders can affect the outcome of the organization and determine the returns that teams obtain by deciding how much risk they take on behalf of team members (Ertac and Gurdal, 2012) or how much effort they exert to increase the team outcome (Ibanez and Schaffland, 2013). Most of all, in hierarchical organizations leaders can use sanctions and rewards to induce higher cooperation. In our analysis, we focus on leaders that have hierarchical power over others or what in the leadership literature is referred to as "transactional leader" (Bass, 1985). To the best of our

\footnotetext{
${ }^{10}$ Similar experimental evidence is provided by Mobius et al. (2011).
} 
knowledge, this is the first paper that analyzes the endogenous emergence of leaders in hierarchical organizations and identifies how the leadership environment affects self-selection into leadership roles. In this way we identify the mechanisms that explain female selfsegregation from the role of norm enforcement.

Empirical evidence supports the view that in hierarchical organizations transactional leaders can use sanctions and rewards to induce higher cooperation. For instance, in the framework of a leading by example experiment, Güth et al. (2007) shows that cooperation is higher when leaders have the power to exclude players from the game. Yet, the effectiveness of exclusion power seems to be restricted to game with homogeneous endowments (Levati et al., 2007). In the framework of a public good game, Van der Heijden, et al. (2009) show that leaders discretionary power to redistribute contributions to the public good game can help to induce higher cooperation levels. They find that transactional leaders forgo the opportunistic behavior and do not appropriate the group contributions. Instead leaders use their discretionary power to reward contributors and exclude free-riders fostering higher cooperation. Gürerk et al. (2009) show that the decision of the leader with respect to the use of negative sanctions increases contributions more than positive rewards. Unlike these papers, that consider second party punishment, in our paper we consider the role of third-party punishment.

Third party punishment is used to characterize situations in which enforcement of the social norm comes at a cost and has no direct personal benefits for the third party. Therefore, sanctions by a third-party can be associated with social reciprocity or preferences for maintaining normative standards (Carpenter and Matthews et al., 2004; Fehr and Gächter, 2002). Recent experimental evidence documents that a large proportion of people are willing to incur costs to enforce norms even when they are not directly affected by the actions. Carpenter and Matthews investigate participant's willingness to incur into costly punishment towards members of their group and towards members of an external group in a public good game. They find substantial degree of punishment towards external group members and a positive effect on this form of punishment on cooperation. Fehr and Fischbacher (2004) report similar results in a dictator game and a prisoner dilemma where the third-party is external to the group and hence have no incentives to build a reputation. We extend this research considering a public good game with endogenous third party punishment.

Relatively, few papers consider the emergence of voluntary leaders. Arbak and Villeval (2013), Haigner and Wakolbinger (2010) and Rivas and Sutter (2011) use the set-up of a 
public good game in which the participants can endogenously determine whether they want to make the contribution before others (lead by example) or wait to contribute after observing first-stage contribution. They find that cooperation increase in treatments with endogenous leaders compared with exogenous leaders. Arbak and Villeval (2013) further explore who is willing to assume the leadership role. They find that female participants are less willing to lead than males but that this difference disappears once that uncertainty about contributions of other group members is removed. Moreover, they find that personality traits, such as generosity and openness, are found to be positively correlated with willingness to lead. Pregner et al. (2012) build upon this literature and find that individuals who can be classified as conditional cooperators are more likely to volunteer to lead than free-riders. Yet, they do not find significant gender differences and female and male participants are equally likely to volunteer to lead. In the context of team game in which leaders have to take risk on behalf of others in the group, Ertac and Gurtel (2012) find that a lower fraction of female participants willing to take risky decisions for the group compared to male participants. Bruttel and Fischbacher (2013) look at leader as innovator the one who takes initiative to push peers payoff up. They find that the willingness to lead is positive correlated with cognitive skills, preferences for efficiency, generosity and patience. They also find that males are more willing to take initiative (lead) in this setting. In a field context Balafoutas and Nikiforakis (2012), find that men are more willing to use sanctions to enforce commonly accepted social norms of courtesy by second party punishment. We contribute to this literature understanding the mechanisms that lead to self-segregation of transactional leaders.

There is a relatively well established literature focusing on gender differences in individual and social preferences (Niederle and Vesterlund, 2007; Gneezy, Niederle and Rustichini, 2003; Eckel and Grossman, 2002; Croson and Gneezy, 2009; Kray, Thompson and Galinsky, 2001; Barber and Odean, 2001; Eagly and Karau, 2002, Asiedu and Ibanez, 2013; Ibanez, et al., 2009). We contribute to this research considering how the society shapes these differences. Gneezy, Leonard and List (2009) use a controlled experiment to explore whether there are gender differences in selecting into competitive environments across two distinct societies: the Maasai in Tanzania and the Khasi in India. Andersen et al. (2010) investigate provision of public good across matrilineal Khasi and patrilineal Kharbi tribes.

We find that gender differences in willingness to take leadership roles are context dependent and to a large extent depend on conformity to the social norms. In matrilineal societies, men are less willing to take leadership roles than women, while in patriarchal societies is the 
opposite. However, this preference seems to be driven by conformity to social norms. Once the leadership role is anonymous, gender differences in willingness to take leadership roles disappear. We also find evidence that supports gender differences in aversion to retaliation as a driving mechanism of segregation in leadership roles. Interestingly, we find heterogeneous effects of affirmative action across societies. While this policy is effective in promoting female leaders in patriarchal society, it discourages female leadership in matrilineal societies. Finally, we find that pecuniary incentives promote females and males to opt in to the power position, however, our evidence also suggest that higher remuneration crowds out voluntary motivation to take the power role and is less effective than affirmative action incentives.

In the next section we presents the local background, Section 3.3 gives details of the experimental design. Section 3.4 presents the results. Section 3.5 concludes.

\subsection{Societal background}

We conducted the experiment with representatives of local tribes in two different states of India: the Santal tribe in West Bengal and the Khasi tribe in Meghalaya. Figure 3.1 presents the location of the tribes where we conducted the experiment. The gray area refers to the Khasi tribe while the black area presents the location of the Santal tribe.

The Khasi is located in the state of Meghalaya, a northeastern state of India. The tribal rules are considered to be matrilineal (Leonetti et al., 2004; Van Ham, 2000). Khasi women have the right to choose their own partner, cohabit and do not require male permission about the marriage. The institution of dowry does not exist; and it is common practice that the man moves to his wife's house after marriage. This stands in sharp contrast to the Indian system of marriage, in which wives always move to their husbands' house after marriage and there is an economically substantial dowry system (Bloch and Rao, 2002; Anderson, 2003). Khasi families are always organized around the female members (mostly around the grandmother who acts as the head of household); and a child always takes the mother's last name. Instead of the oldest son, the youngest daughter inherits all property establishing women power in the society. It is also an effective way to ensure that the youngest daughter is always around as a support to her parents in their old age. Interestingly, property rights for the youngest daughter and consequential old age support make son preference absent in the society. Incidence of female feticide and domestic violence against women is rare and intra-household access to health, education, and nutrition is equal among male and female family members (for more details see Andersen et al., 2008, 2010 and Gneezy, Leonard and List, 2009). With the Khasi, farming is the major economic activity and production is generally controlled by female 
members of the family. In addition to farming, women undertake all other economic activities and are often involved in trading with men from other societies.

The Santal is the largest tribal group of eastern India and is distributed over the states of Bihar, Orissa, and Tripura as well as in West Bengal, where our study was conducted. The Santal society is patriarchal and giving women little decision rights and put them in lower status than men. Santal customary law does not guarantee women inheritance rights in their parental property. They however have contingent rights to inheritance depending upon the circumstances. For instance, a common practice is to endow a married woman with some land in her natal village as a mean to provide financial support in case of unsuccessful marriage. However, according to the Santal Pargana Tenancy Act (SPTA), 1949, in absence of appropriate male heirs, the daughter inherits her father's land (Rao, 2010). Caring for parents in their old age is the responsibility of sons not of daughters. Once married, daughters are expected to spend their life under the supervision of their husbands or other elder men in the husband's family. A post experimental survey in our study revealed that female mobility even within the community is restricted and visiting parents, relatives; friend by women always requires taking permission from the adult male in the family. Low female mobility has also resulted in lower labor force participation by women. Similarly, expenditure decisions are mostly taken by men in the family, which is even triggered by the fact that in most household men are the major income earning members. Women's work and work experience differs significantly from those of men, and in some areas women are completely excluded from industrial work (Roy and Murry, 2013). The distribution of family resources among male and female members is unequal and even though women contribute significant amounts of labor to family farms, income earned mostly remains under the control of men. The Santal social norms are not an exception to the Hindu norms of favoring boys over girls, and son preference is prominent. 


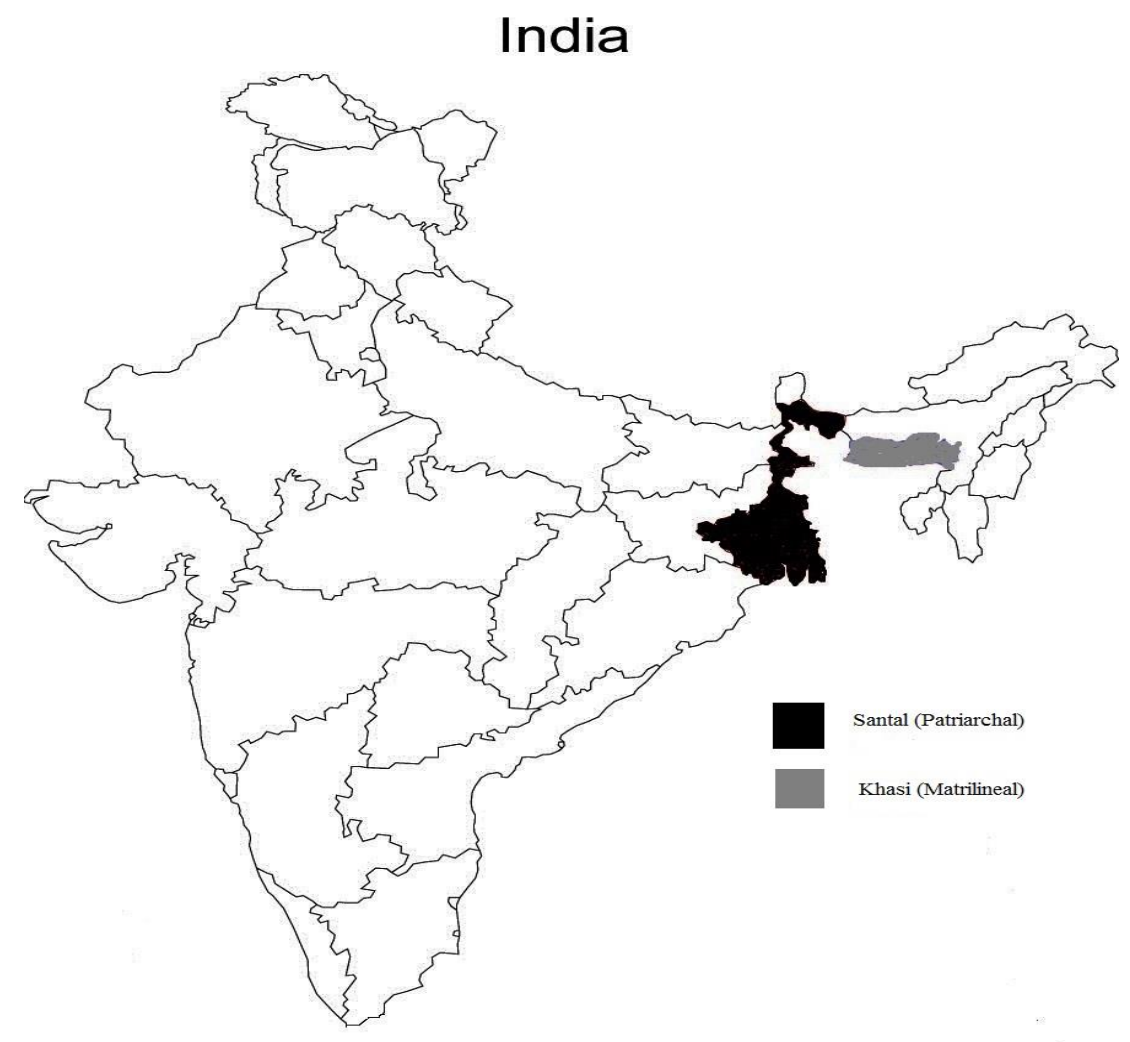

Figure 3.1: Location of Santal and Khasi on the India

\subsection{Experimental design}

Our experimental design is based on a public good game with endogenous third party punishment. We form random and anonymous groups with four participants. Three participants in the group take the role of contributors and one participant takes the role of third-party. Let $\mathrm{L}$ denote the third-party punisher. Each contributor receives an initial endowment of Rs.30 and participates in a one-shot linear public good game with third party punishment. A contributor has to decide how to allocate the endowment between a private account and a group account. Let the contribution to the group account be denoted by $\mathrm{c}_{\mathrm{i}}$. The marginal per-capita return (MPCR) for investing in the group good is $\beta=2 / 3$, while the marginal per capita return from the individual account is set to one. The third party receives and initial endowment of $\mathrm{w}=$ Rs.50 and the task is to observe the individual contributions and to decide whether to punish contributors. Each punishment points assigned to contributor idenoted by $\mathrm{P}_{\mathrm{Li}}$ - costs one experimental unit to the third party and decreases i's payments by three experimental units. The third party can assign punishment points from $0 ; \ldots ; 5$ to each contributor. Subsequently contributors are informed about the contribution of other group members and the punishment decisions of the third party. At this stage contributors have the 
possibility to counter punish the third party. Counter punishment is costly for both the contributor and the third party. Each counter punishment point, denoted by $\mathrm{Q}_{\mathrm{iL}}$, costs one to the contributor and decreases income of the third party in two points. Since the third party can give feedback and receive feedback, we denominate this treatment Giving and receiving punishment (henceforth GRP).

The third-party does not contribute to the group account and does not receive any payment from the group contributions. The pay-off function for the contributors, $\pi_{\mathrm{i}}$, and third party, $\mathrm{v}_{\mathrm{L}}$, are:

$$
\begin{gathered}
\pi_{i}\left(c_{i}, \beta, Q_{i L}, P_{L i}\right)=30-c_{i}+\beta \sum_{j \in I \neq i}\left(c_{j}-3 P_{L i}-3 Q_{i L}\right) \ldots \ldots(1) \\
v_{L}=w-\sum_{i=1}^{3}\left(P_{L i}+2 Q_{i L}\right) \ldots \ldots(2)
\end{gathered}
$$

For a one shot game, as the one that we implement, the unique Nash equilibrium assuming payoff maximizing individuals is to run for leadership when $\mathrm{w}>30$ and to assign zero punishment points and zero counter punishment points $\left(\mathrm{P}_{\mathrm{Li}}=\mathrm{Q}_{\mathrm{Li}}=0\right)$. Since the following condition is satisfied, $0<1<3 \mathrm{n}$, the dominant strategy for the contributors is to choose $\mathrm{c}_{\mathrm{i}}$ equal to zero. However, the Pareto optimal outcome is reached when all three members contribute the full endowment to the group account.

The game consisted of eight stages as illustrated in Table 3.1. After reading the instructions and making sure that participants understood the incentives and the structure of the game, participants could decide on their preferred role framed as role A for contributors and role B for the third party. In case that more than one group member was willing to take the role of the third-party, one participant was selected randomly among willing candidates. Similarly, in case that no one wanted to assume the role of third-party punisher - one subject was randomly among all group members ${ }^{11}$.

While the roles were assigned before knowing which role they would actually play, in the third and fourth stages all participants were asked to make their contribution decision and to state their expectation on the average contribution of the others in the group. In the fifth stage, participants selected as third-party were required to stand up and greet other participants.

\footnotetext{
${ }^{11}$ To avoid confounds that would result from aversion to competition we do not use voting to determine the leader.
} 
Hence contributors could see the faces of all participants selected as third party. In sessions we had $\mathrm{m}>1$ groups; therefore contributors would not know who of the $\mathrm{m}$ third-party is responsible for observing decisions and deciding on sanctioning points for his group. Similarly, third-party does not know the identity of contributors in their group. We decided not to reveal the matching of the candidates with the groups to avoid potential confounds and potential post-experimental effects. In the sixth stage while the third party observes the individual contribution and decides on the allocation of punishment points, contributors state their expectations on punishment points. In the seventh stage, the punishment decisions along with corresponding contribution decisions are made public within the group and contributors can allocate counter punishment points. At the end of each session, participants receive information on the points earned in the game and were paid out in private.

Table 3.1: Experimental schedule

\begin{tabular}{|c|c|c|}
\hline & \multicolumn{2}{|c|}{ All subjects } \\
\hline Stage 1 & \multicolumn{2}{|c|}{ Instructions } \\
\hline Stage 2 & \multicolumn{2}{|c|}{ Role choice } \\
\hline Stage 3 & \multicolumn{2}{|c|}{ Contribution decision } \\
\hline Stage 4 & \multicolumn{2}{|c|}{ Average expected contribution } \\
\hline Stage 5 & \multicolumn{2}{|c|}{ Leader assignment } \\
\hline & Leaders & Contributors \\
\hline Stage 6 & Assign punishment points & Elicit expected punishment \\
\hline Stage 7 & Expected counter punishment & [Counter punishment points] \\
\hline Stage 8 & \multicolumn{2}{|c|}{ Feedback on outcome of the game } \\
\hline
\end{tabular}

Note: This table schematically represents the schedule of the experiment. Instructions were read out loud and the main points were summarized on flipcharts. Expectation of contributions and own contribution were elicited from all subjects in order to control for the relative monetary attractiveness of either option. The leader assignment was randomized uniformly from the candidates determined in Stage 2. In Stage 7, the counter punishment points were only given in treatments with counterpunishment.

\subsubsection{Treatment}

Our experimental design is based on a between with-in subject design as we explain with more detail below.

\section{Between subjects Treatments}

We consider the Giving and Receiving Punishment Treatment (GRP) as a base line and implement additional treatments modifying one element of the game at a time. The first treatment is denominated Giving Punishment (GP). This treatment evaluates whether aversion to feedback deters women to assume the role of third-party. This treatment is identical to the Giving and Receiving punishment treatment, except that contributors do not have the possibility to counter punish third parties. As the expected cost of taking the leadership role 
decreases, we expect that a larger fraction of participants would be willing to assume the role of third-party in the GP treatment compared with the GRP treatment. If gender differences in aversion to feedback or in risk aversion are driving self-selection from leadership roles, we expect that this treatment would reduce gender gaps in willingness to take the role of third party compared with the GRP treatment.

The second treatment is denominated Anonymous Giving and Receiving Punishment (AGR). In this treatment the identity of the third party is not revealed. Hence participants who are assigned the role of third party punishment to not stand up and greet other participants. The identification of the third parties remains anonymous. In this treatment only the third party knows his role but has no opportunity to reveal this information to contributors during the experiment. All other procedures are identical to the Giving and Receiving Punishment (GRP) treatment. If self-selection from leadership roles is due to gender differences in reputation concerns, we expect that this treatment will decrease gender gaps in the fraction of participants who volunteer to lead in the AGR treatment compared with the GRP treatment.

One policy that is commonly used to foster female participation is affirmative action. In the experiment we explore the effect to affirmative action policies that give preferential treatment to women implementing an Affirmative action treatment (GRPAA). In this treatment, female subjects willing to take the role of third party were given preference over the male subjects. In case that more than one woman was willing to take the third party role, the role was assigned randomly among willing female candidates. Everything else was the same as the Giving and Receiving punishment (GRP) treatment. As the Affirmative Action policy decreases competition for the role of third party, we expect that a larger fraction of women would be willing to take this role under the GRPAA compared with the GRP treatment.

All four treatments were implemented in the two societies that vary the degree of female empowerment. As described before in more detail, the Santal region is characterized by a patriarchal system where women have low empowerment, while the Khasi region is characterized by a matrilineal system with women occupying important roles in the society. We expect that social differences in female empowerment will be reflected in the experiment. Hence we expect that the fraction of female participants willing to assume the role of third party will be lower in the Santal region than in the Khasi region under the GRP treatment. If nature affects gender differences in aversion to feedback and aversion to assume public roles, we expect that treatments that increase the degree of anonymity of the third party and that decrease counter punishment would result in even larger fraction of women taking the role of 
third party compared with the GRP treatment. Similarly, we expect that a larger fraction of female participants will volunteer to take the role of third party under the treatment that gives preferential treatment to female candidates. On the other hand if society differences affect gender differences in feedback aversion and aversion to public roles, we expect that the fraction of male candidates willing to assume the role of third party will increase in the GP and AGR treatments compared with the GRP treatment. Table 3.2 summarizes the between subject treatments implemented in the experiment.

Table 3.2: Treatment Description

\begin{tabular}{lcccc}
\hline & & Criticism & \multicolumn{2}{c}{ Policy Instrument } \\
\hline Third -party Role & $\begin{array}{c}\text { Giving } \\
\text { Punishment }\end{array}$ & $\begin{array}{c}\text { Giving \& Receiving } \\
\text { Punishment }\end{array}$ & Affirmative Action \\
\hline Patriarchal & Public & GP & GRP & GRPAA \\
Matrilineal & Anonymous & - & AGR & GRP \\
& Public & GP & AGR & GRPA \\
\hline
\end{tabular}

Note: Treatments- (1) Giving \& Receiving Punishment in Public: GRP; (2) Giving and Receiving Punishment under Anonymity: GRA; (3) Giving Punishment in Public: GP; (4) Giving \& Receiving Punishment in Public under Affirmative Action: GRPAA. The same treatments were implemented in the two societies, which are in total $42=8$ conditions.

\section{With-in subjects treatments}

After completing the first one-shot game, participants were re-matched in new groups and participated in a second public good game with third party. The conditions of the game were exactly the same as in the first one-shot public good game so they remained in the same between treatments played in the first one shot public good game. Once again, participants are asked their willingness to assume the role of third-party. The only difference was that we varied the reward offered to the third-party. While in the first one shot game we kept a wage, $\mathrm{w}$, of Rs.50, in the second one shot game subjects were presented with four different wage levels in a form of a choices list. In this case the wage was Rs. 30, Rs. 50, Rs. 70 and Rs. 90. From each group one of the wage choices was randomly selected and among the willing members to take the role of third party was chosen randomly among willing candidates for that giving wage. Contributors' initial endowment was kept at the same level Rs.30. By varying the reward level of the third party we can investigate the relative effectiveness of rewards to induce participants to take the role of third-party. We expect that a higher reward will increase the incentive to take the role of third party and will increase the fraction of participants willing to take the role of third party. 


\subsubsection{Experimental procedures}

The experiment was conducted between September 2012 and January 2013 in the states of Meghalaya and West Bengal. The research design is identical in the two states and was conducted in three districts of Meghalaya (Ribhoi, East Khasi Hills and Jaintia Hills) and one district in West Bengal (Purulia). In total 224 subjects in Meghalaya and 336 subjects in West Bengal participated in the experiment. We expect that our selection of societies will provide contrasting behavioral differences by gender and by tribes. We conducted 36 sessions, 15 in the matrilineal society and 21 in the patriarchal society. Each session consists of three or four groups of four. Table 3.3 summarizes the number of subjects by society and treatment. At the end, the final payment was calculated and paid depending on the outcome of the game.

Table 3.3: Number of subjects by treatment

\begin{tabular}{lccc}
\hline Treatment & \multicolumn{3}{c}{ PatriarchalMatrilineal Total } \\
\hline Giving \& Receiving Punishment (GRP) & 96 & 60 & 156 \\
Anonymous Giving and Receiving Punishment (AGR) & 80 & 60 & 140 \\
Giving Punishment (GP) & 80 & 40 & 120 \\
Giving and Receiving Punishment under Affirmative Action (GRPAA)80 & 64 & 144 \\
\hline Total & 336 & 224 & 560 \\
\hline
\end{tabular}

\subsection{Results}

\subsubsection{Descriptive statistics}

Descriptive statistics on socioeconomic characteristics collected in the post-experimental survey are presented in Table 3.4. The average age of our sample of participants is 33 years. We do not find significant differences in age of the male participants across treatments or societies. However, female participants in the matrilineal Khasi region are slightly older than male participants in the region than female participants in the patriarchal Santal region. The household size in Khasi region is significantly higher than in the Santal region, where the average number of children under 5 is also significantly larger. Consistent with our hypothesis, we find that in the Khasi region, the share of male household heads is lower than in the Santal Region. Participants in our sample have a relatively low education level and $40 \%$ of the participants in the Santal region have secondary education at most whereas in the Khasi region, $60 \%$ of the participants have secondary education.

\subsubsection{Self-selection into the role of third-party}

\section{First One Shot Public Good Game}


Descriptive statistics of the proportion of male and female participants who selected the role of the third-party by treatment and society are presented in Table 3.5. We find that in the Giving and Receiving treatment (GRP) there are sizable gender differences in the willingness to take the role of third party. However, these differences vary according to the type of society. While in the patriarchal society men are more willing to volunteer, in the matrilineal society is the opposite and women are more likely to be willing to assume this role. This is consistent with the cultural differences in explaining appropriated gender roles. 
Table 3.4: Socio-economic characteristics and randomization check

\begin{tabular}{|c|c|c|c|c|c|c|c|c|c|c|}
\hline & \multicolumn{4}{|c|}{ Matrilineal Society } & \multirow[b]{2}{*}{ Total } & \multicolumn{4}{|c|}{ Patriarchic Society } & \multirow[b]{2}{*}{ Total } \\
\hline & GP & GRP & AGR & GRPAA & & GP & GRP & AGR & GRPAA & \\
\hline Age & $\begin{array}{c}32.833 \\
(1.836)\end{array}$ & $\begin{array}{c}33.552 \\
(2.678)\end{array}$ & $\begin{array}{c}29.950 \\
(1.793)\end{array}$ & $\begin{array}{l}31.489 \\
(1.594)\end{array}$ & $\begin{array}{c}31.581 \\
(0.963)\end{array}$ & $\begin{array}{l}32.795 \\
(1.246)\end{array}$ & $\begin{array}{c}34.471 \\
(1.235)\end{array}$ & $\begin{array}{l}38.526 \\
(1.289)\end{array}$ & $\begin{array}{l}34.662 \\
(1.499)\end{array}$ & $\begin{array}{l}35.132 \\
(0.674)\end{array}$ \\
\hline Household size & $\begin{array}{c}6.750 \\
(0.443)\end{array}$ & $\begin{array}{c}7.250 \\
(0.635)\end{array}$ & $\begin{array}{c}7.450 \\
(0.345)\end{array}$ & $\begin{array}{c}7.021 \\
(0.502)\end{array}$ & $\begin{array}{c}7.152 \\
(0.229)\end{array}$ & $\begin{array}{c}6.762 \\
(0.331)\end{array}$ & $\begin{array}{c}4.838 \\
(0.207)\end{array}$ & $\begin{array}{c}5.713 \\
(0.295)\end{array}$ & $\begin{array}{c}6.900 \\
(0.401)\end{array}$ & $\begin{array}{c}6.101 \\
(0.168)\end{array}$ \\
\hline Children under 5 years & $\begin{array}{c}0.833 \\
(0.162)\end{array}$ & $\begin{array}{c}1.571 \\
(0.238)\end{array}$ & $\begin{array}{c}2.085 \\
(0.355)\end{array}$ & $\begin{array}{c}1.340 \\
(0.303)\end{array}$ & $\begin{array}{c}1.529 \\
(0.161)\end{array}$ & $\begin{array}{c}0.837 \\
(0.098)\end{array}$ & $\begin{array}{c}0.478 \\
(0.091)\end{array}$ & $\begin{array}{c}0.846 \\
(0.121)\end{array}$ & $\begin{array}{c}0.850 \\
(0.107)\end{array}$ & $\begin{array}{c}0.764 \\
(0.053)\end{array}$ \\
\hline Household head male & $\begin{array}{c}0.611 \\
(0.082)\end{array}$ & $\begin{array}{c}0.483 \\
(0.094)\end{array}$ & $\begin{array}{c}0.550 \\
(0.077)\end{array}$ & $\begin{array}{c}0.681 \\
(0.069)\end{array}$ & $\begin{array}{c}0.587 \\
(0.040)\end{array}$ & $\begin{array}{c}0.875 \\
(0.037)\end{array}$ & $\begin{array}{c}0.868 \\
(0.046)\end{array}$ & $\begin{array}{c}0.962 \\
(0.021)\end{array}$ & $\begin{array}{c}0.863 \\
(0.039)\end{array}$ & $\begin{array}{c}0.893 \\
(0.018)\end{array}$ \\
\hline Primary education & $\begin{array}{c}0.194 \\
(0.067)\end{array}$ & $\begin{array}{c}0.143 \\
(0.067)\end{array}$ & $\begin{array}{c}0.100 \\
(0.039)\end{array}$ & $\begin{array}{c}0.170 \\
(0.055)\end{array}$ & $\begin{array}{c}0.146 \\
(0.027)\end{array}$ & $\begin{array}{c}0.087 \\
(0.032)\end{array}$ & $\begin{array}{c}0.279 \\
(0.055)\end{array}$ & $\begin{array}{c}0.225 \\
(0.047)\end{array}$ & $\begin{array}{c}0.062 \\
(0.027)\end{array}$ & $\begin{array}{c}0.159 \\
(0.021)\end{array}$ \\
\hline Secondary education & $\begin{array}{c}0.639 \\
(0.081)\end{array}$ & $\begin{array}{c}0.429 \\
(0.095)\end{array}$ & $\begin{array}{c}0.567 \\
(0.065)\end{array}$ & $\begin{array}{c}0.702 \\
(0.067)\end{array}$ & $\begin{array}{c}0.596 \\
(0.038)\end{array}$ & $\begin{array}{c}0.412 \\
(0.055)\end{array}$ & $\begin{array}{c}0.412 \\
(0.060)\end{array}$ & $\begin{array}{c}0.312 \\
(0.052)\end{array}$ & $\begin{array}{c}0.488 \\
(0.056)\end{array}$ & $\begin{array}{c}0.406 \\
(0.028)\end{array}$ \\
\hline $\mathrm{N}$ & 40 & 60 & 60 & 64 & 224 & 80 & 96 & 80 & 80 & 336 \\
\hline
\end{tabular}

Note: This table reports the summary statistics of individual demographic and village level variables comparing male and female by society. Significance of the differences evaluated with t-tests are reported in Appendix 3A. 
In the Giving Punishment treatment under which the contributors cannot counter punish the third party. Motives such as gender differences in risk aversion or aversion to feedback are taken away. Hence if gender differences in risk aversion or feedback aversion determine gender gaps in the preference for the role of the third party, we would expect that the gender gap would be reduced in this treatment. Indeed we find that this treatment is effective in reducing the gender differences in willingness to select the role of third-party punisher. Compared to the baseline treatment, female participants in the patriarchal society and male participants in the matrilineal society are significantly more likely to accept the role of third party punisher. Surprisingly, in the matrilineal society female participants are less likely to volunteer to the role of third party when counter punishment is removed. This suggests that in the matrilineal society women have a preference for being held accountable, as expected in their role. This result indicates that gender differences in willingness to take the role of third party are due to social norms and are not innate.

The second treatment that we implement aims at testing whether conformity with social roles drives gender differences in willingness to take the role of the third party. Comparing choices for the role of third party in the treatment Anonymous Giving and Receiving (AGR) with the Giving and Receiving Punishment Treatment (GRP), we find that gender differences in the willingness to take the role of third party disappear once that identity of the third party is removed. This is consistent with differences in image concern or conformity with social roles. Santal women and Khasi men are significantly more likely to volunteer to the role of third party. The share of Khasi men volunteering for the role of third party increases from $25 \%$ to $47.4 \%$ while the share of Santal women increases from $23 \%$ to $44 \%$. In contrast, in the matrilineal society there is a significant decline in women's willingness to assume the role of third party from $53.1 \%$ in the GRP to $29.3 \%$ under AGR. These results indicate that fear of exposure and adherence to social norms under public observation play an important role in women's self-selection into leadership positions. As the effect of the treatment differs by society, it seems that cultural norms rather than innate factors affect gender segregation in leadership roles. 
Table 3.5: Proportion of subjects applying for punisher by society and gender

\begin{tabular}{lccccccc}
\hline & \multicolumn{3}{c}{ Patriarchal (Santal) } & \multicolumn{3}{c}{ Matrilineal (Khasi) } \\
\hline & \multicolumn{3}{c}{ Male- } \\
& Male & Female & Female & \multicolumn{3}{c}{ Male } & Female Male-Female. \\
& $\%$ & $\%$ & p-value & $\%$ & $\%$ & p-value \\
Giving \& Receiving Punishment (GRP) & 42.5 & 23.2 & 0.03 & 25 & 53.1 & 0.03 \\
Giving Punishment (GP) & 41.7 & 36.4 & 0.63 & 60 & 36.7 & 0.2 \\
Anonymous Giving \& Receiving Punishment (AGR) & 38.6 & 44.4 & 0.6 & 47.4 & 29.3 & 0.17 \\
Giving \& Receiving Punishment under AA (GRPAA) & 25.0 & 41.7 & 0.11 & 19.4 & 27.3 & 0.54 \\
& & & & & &
\end{tabular}

Note: This table reports the choice for leadership by treatment, gender and society. The differences are evaluated using Wilcoxon rank-sum tests.

The last treatment that we implemented aimed at testing the effectiveness of affirmative action policies in inducing women to assume the role of third party. Comparing the treatment Giving and Receiving Punishment under Affirmative Action (GRPAA) we find that Santal females increased their willingness to take the role of third party from $23.2 \%$ to $41.7 \%$. However, increased female participation comes at a cost of less male participants in Santal region willing to assume the role of third party. Interestingly, we find heterogeneous effects across the two societies. In the matrilineal society, the proportion of female participants opting for the role of third party decreases significantly from $53.1 \%$ to $27.3 \%$ under affirmative action in comparison to the Giving and Receiving Punishment Treatment. While the proportion of male participants decrease slightly, this effect is not significant. This suggests that in a setting where women already enjoy a higher status, preferential treatment for women might result in crowding out of intrinsic motivation to assume the role of third party probably as this policy make women to appear as less empowered and inferior to men.

\section{Second One Shot Public Good Game}

The second part of the analysis considers the effect of pecuniary incentives on participants' willingness to assume the role of the third party. Table 3.6 reports the proportion of male and female candidates who volunteer to take the role of third party by wages, treatments and societies. We implemented four wage treatments, Rs.30, Rs. 50, Rs. 70, Rs. 90. This allows us to evaluate the effectiveness of monetary incentives in reducing the observed gender differences.

We find that the results of the second one-shot public good game roughly replicate the results from 
the first one-shot public good game. In the treatment Giving and Receiving Punishment female participants self-segregate out from the role of third party in the patriarchal society while in the matrilineal society male participants self-segregate out. Second, changes in the organizational environment that eliminate counter punishment or that increase anonymity is effective in decreasing the gender gap. Female participants in Santal region and male participants in Khasi region are significantly more likely to volunteer to take the role of third party under these treatments compared with the treatment Giving and Receiving Punishment. Third, the treatment with affirmative action is effective in increasing the fraction of women who volunteer to take the role of third party in the Santal society and significantly reduces the fraction of female candidates willing to assume this role in the Khasi society.

The second one shot public good game reveals other interesting results. In the Giving and Receiving Punishment treatment, changes in the wage of the third-party foster male participants in the Santal society and female participants in the Khasi region to assume this role, However, changes in the wages are much less effective in increasing representation of the under-represented gender. Hence, the gender gap persists and even broadens despite the higher wages. In contrast changes in the organizational environment result in higher participation of the deprived gender. We find that increases in wages have the expected result and is effective in fostering female participants in the Santal region to take the role of third party but have limited effect on male participants in Khasi region. Interestingly, we find that the combination of increased wages and changes in the organizational environment can actually decrease the proportion of participants willing to take the role of third party. One explanation of such trend is that higher wages generate higher sense of responsibility which in turn causes participation in leadership roles to decrease. This effect is particularly salient for the relatively underrepresented gender when the wage is nearly doubled to Rs. 90.

Our results suggest that a pecuniary incentive has limited effectiveness and can actually increase the gender gaps. Changes in organizational environment seem to be a more promising alternative to foster female empowerment.

In Santal region as participants gain experiences in the game they are more likely to volunteer to take the role of third party. A larger fraction of male and female participants are willing to take the role of third party in the second one-shot public good game compared with the first one-shot game. 
Hence, gender differences in willingness to take the role of leader disappear in the Giving and Receiving Punishment treatment when the wage is equal or lower than Rs.50 and reverse in the treatment Anonymous Giving and Receiving Punishment.

Table 3.6: Proportion of subjects applying for punisher by society, gender and wage

\begin{tabular}{|c|c|c|c|c|c|c|c|c|}
\hline \multirow[t]{2}{*}{ Panel A: Male } & \multicolumn{4}{|c|}{ Patriarchal } & \multicolumn{4}{|c|}{ Matrilineal } \\
\hline & W30 & W50 & W70 & W90 & W30 & W50 & W70 & W90 \\
\hline GRP & 0.48 & 0.58 & 0.75 & 0.78 & 0.18 & 0.29 & 0.64 & 0.29 \\
\hline AGR & 0.45 & 0.55 & 0.59 & 0.45 & 0.63 & 0.53 & 0.53 & 0.53 \\
\hline GP & 0.58 & 0.67 & 0.64 & 0.67 & 0.60 & 0.80 & 0.70 & 0.5 \\
\hline GRPAA & 0.30 & 0.27 & 0.39 & 0.36 & 0.23 & 0.39 & 0.35 & 0.42 \\
\hline p:(AGR-GRP) & 0.85 & 0.79 & 0.13 & $0.00 * * *$ & $0.00 * * *$ & 0.10 & 0.44 & 0.10 \\
\hline p:(GP-GRP) & 0.35 & 0.42 & 0.30 & 0.30 & $0.01 * *$ & $0.00 * * *$ & 0.75 & 0.23 \\
\hline p:(GRPAA-GRP) & $0.09 *$ & $0.00 * * *$ & $0.00 * * *$ & $0.00 * * *$ & 0.66 & 0.42 & $0.03 * *$ & 0.29 \\
\hline \multirow[t]{2}{*}{ Panel B: Female } & \multicolumn{4}{|c|}{ Patriarchal } & \multicolumn{4}{|c|}{ Matrilineal } \\
\hline & W30 & W50 & W70 & W90 & W30 & W50 & W70 & W90 \\
\hline GRP & 0.36 & 0.55 & 0.46 & 0.46 & 0.56 & 0.50 & 0.63 & 0.72 \\
\hline AGR & 0.50 & 0.75 & 0.81 & 0.75 & 0.27 & 0.29 & 0.20 & 0.39 \\
\hline GP & 0.36 & 0.70 & 0.70 & 0.75 & 0.40 & 0.30 & 0.40 & 0.33 \\
\hline GRPAA & 0.39 & 0.61 & 0.81 & 0.61 & 0.18 & 0.27 & 0.24 & 0.27 \\
\hline p:(AGR-GRP) & 0.18 & $0.06^{*}$ & $0.00 * * *$ & $0.01 * *$ & $0.01 * *$ & $0.07 *$ & $0.00 * * *$ & $0.00^{* * *}$ \\
\hline $\mathrm{p}:(\mathrm{GP}-\mathrm{GRP})$ & 0.95 & 0.12 & $0.02 * *$ & $0.00^{* * *}$ & 0.21 & 0.11 & $0.08^{*}$ & $0.00^{* * *}$ \\
\hline p:(GRPAA-GRP) & 0.76 & 0.59 & $0.00 * * *$ & 0.17 & $0.00 * * *$ & $0.06 * *$ & $0.00 * * *$ & $0.00 * * *$ \\
\hline
\end{tabular}

Note: The numbers indicate percentage of subjects opted for leadership; for the treatment comparison GRP is always taken as baseline treatment; probabilities for are reported for Wilcoxon rank-sum test statistics; ${ }^{* * *} \mathrm{p}<0.01,{ }^{* *} \mathrm{p}<0.05$, $* \mathrm{p}<0.1 ; 12.8 \%$ showed inconsistent preference, however, they are included in the analysis.

\subsubsection{Regressions analysis}

\section{First one-shot public good game}

In previous studies correlations have been reported on how individual characteristics other than gender are correlated with the willingness to take up power positions (A. H. Eagly and S. J. Karau, 2002; K.Y. Chan and F. Drasgow, 2001). To understand how treatments affect the willingness to volunteer to the role of third party $-\mathrm{L}-$ we integrate socioeconomic controls in a regression framework to obtain a more fine grained understanding of our results. We estimate the following linear probability model with interactions between the treatments and a dummy for female subjects.

$$
L=\beta_{0}+\beta_{1} \text { female }+\beta_{2} A G R+\beta_{3} G P+\beta_{4} G R P A A
$$


$+\beta_{5} A G R$ female $+\beta_{6} G P$ female $+\beta_{7} G R P A A$ female + Icontrols $+e$

(3)

$\beta_{1}, \beta_{5}, \beta_{6}$ and $\beta_{7}$ measure the gender gap in willingness to assume the role of third party in the treatments GRP, AGR, GP and GRPAA, respectively. Table 3.7 reports the estimated coefficients for gender differences.

Table 3.7:Marginal effects of choice of leadership application from a linear probability model

\begin{tabular}{|c|c|c|c|c|c|c|}
\hline & \multicolumn{3}{|c|}{ Patriarchic } & \multicolumn{3}{|c|}{ Matrilineal } \\
\hline & Raw & Expectations & Demographics & Raw & Expectations & Demographics \\
\hline \multirow[t]{2}{*}{ Constant (GRP -Male) } & $0.42 * * *$ & $0.62 * * *$ & $0.64 * * *$ & $0.25 * * *$ & $0.60 * * *$ & $0.47 * *$ \\
\hline & $(0.08)$ & $(0.15)$ & $(0.22)$ & $(0.08)$ & $(0.17)$ & $(0.23)$ \\
\hline \multirow[t]{2}{*}{ Giving Punishment } & -0.01 & -0.03 & -0.03 & $0.35^{*}$ & $0.36^{* *}$ & $0.38 *$ \\
\hline & $(0.11)$ & $(0.12)$ & $(0.12)$ & $(0.18)$ & $(0.17)$ & $(0.20)$ \\
\hline \multirow[t]{2}{*}{ Anonymous Giving Receiving } & -0.04 & -0.05 & -0.00 & 0.22 & 0.22 & $0.30 *$ \\
\hline & $(0.11)$ & $(0.11)$ & $(0.12)$ & $(0.14)$ & $(0.14)$ & $(0.16)$ \\
\hline \multirow[t]{2}{*}{ Affirmative Action } & $-0.17 *$ & $-0.19 *$ & -0.15 & -0.04 & -0.03 & 0.00 \\
\hline & $(0.10)$ & $(0.10)$ & $(0.11)$ & $(0.11)$ & $(0.11)$ & $(0.14)$ \\
\hline \multirow[t]{2}{*}{ Female } & $-0.19 * *$ & $-0.20 * *$ & -0.07 & $0.28 * *$ & $0.29 * *$ & $0.43 * *$ \\
\hline & $(0.10)$ & $(0.10)$ & $(0.12)$ & $(0.12)$ & $(0.12)$ & $(0.19)$ \\
\hline Giving Public $*$ female & 0.14 & 0.16 & 0.10 & $-0.51 * *$ & $-0.55 * *$ & $-0.60 * *$ \\
\hline Anonymous Giving Receiving * & $(0.15)$ & $(0.15)$ & $(0.16)$ & $(0.22)$ & $(0.22)$ & $(0.27)$ \\
\hline \multirow[t]{2}{*}{ female } & $0.25^{*}$ & $0.27 *$ & 0.18 & $-0.46 * *$ & $-0.48 * * *$ & $-0.63 * * *$ \\
\hline & $(0.15)$ & $(0.15)$ & $(0.17)$ & $(0.18)$ & $(0.18)$ & $(0.23)$ \\
\hline \multirow[t]{2}{*}{ Affirmative Action $*$ female } & $0.36^{* *}$ & $0.36^{* *}$ & 0.25 & -0.24 & -0.24 & -0.31 \\
\hline & $(0.14)$ & $(0.14)$ & $(0.16)$ & $(0.16)$ & $(0.16)$ & $(0.23)$ \\
\hline \multirow[t]{2}{*}{ Expected Pay PG } & & -0.00 & $-0.01 *$ & & $-0.01 * *$ & $-0.01 * *$ \\
\hline & & $(0.00)$ & $(0.00)$ & & $(0.00)$ & $(0.00)$ \\
\hline \multirow[t]{2}{*}{ Age } & & & -0.00 & & & 0.00 \\
\hline & & & $(0.00)$ & & & $(0.00)$ \\
\hline \multirow[t]{2}{*}{ Household size } & & & -0.01 & & & 0.00 \\
\hline & & & $(0.01)$ & & & $(0.01)$ \\
\hline \multirow[t]{2}{*}{ Children under 5 years } & & & 0.02 & & & -0.01 \\
\hline & & & $(0.03)$ & & & $(0.02)$ \\
\hline \multirow[t]{2}{*}{ Household head male } & & & 0.08 & & & -0.03 \\
\hline & & & (0.09) & & & $(0.07)$ \\
\hline \multirow[t]{2}{*}{ Secondary education } & & & $0.11 *$ & & & -0.02 \\
\hline & & & $(0.06)$ & & & $(0.08)$ \\
\hline Observations & 336 & 336 & 302 & 224 & 223 & 168 \\
\hline
\end{tabular}

Note: This table reports the result of a linear probability model. Baseline treatment in all models is Giving and Receiving in Public. After including socio-economic controls sample size for matrilineal Khasi decreases as some subjects were not able to complete the post experimental survey.

Column1 presents the results without controlling for socio-economic characteristics of the 47 
participants, in column 2 we control for the expected pay-off of being a contributor in the game. This value is estimated according to the pay-off function (1), taking in to account the elicited beliefs on the expected contribution of other group members. The purpose of including this variable is to examine whether expected income ${ }^{12}$ from the public good game has any impact on role selection. One valid concern is whether women self-select out from leadership roles as they perceived that female leadership generate sub-optimal outcomes in terms of lower cooperation and thus lower income. The last model controls for expected income, and socio-economic characteristics of the participants.

The estimated models corroborate our previous results. The gender gap in the role selection decreases in treatments that change organizational environment. Under environment where the role of the leader is anonymous or where there is no counter punishment, the under-represented gender is more likely to assume the role of third party. Yet, once that we include controls for socioeconomic characteristics, the significance of the coefficients falls. In particular, the gender difference in the patriarchal society becomes not significant, indicating that other socio-economic factors can be affecting role selection. In particular in the patriarchal society age and education seem to be positively correlated with the selection into the role of the third party.

\section{Second one-shot public good game}

Each participant took four independent decisions in the second one shot game. Hence we consider how willingness to assume the role of third party- $-\mathrm{L}$ - changes with the offered wage. We estimate following model using random effects ordinary least squares:

$$
\begin{aligned}
L_{i t} & =\beta_{0}+\beta_{1 \text { wage }_{i t}}+\beta_{2} \text { wage }_{i t}^{2}+\beta_{3 \text { female }_{i}}+\beta_{4 \text { wage }_{i t}} * \text { female }_{i} \\
& +\beta_{5 \text { wage }_{i t}{ }^{2} \text { female }_{i}}+\text { Icontrols }+€
\end{aligned}
$$

Table 3.8 presents the results by treatment and society. We find that in the Giving and Receiving Treatment increases in wages induce more participants to assume the role of third party; however, the effect is significant only in the Khasi region. Moreover, we find that in this region, higher salaries are associated with a lower fraction of female participants willing to take the role of third-

\footnotetext{
12 The expected income from the public good game is defined as $\mathrm{E}(\mathrm{Payoff})=30$ own contribution $+(2$ (own contribution + 2 expected contribution) $=3$ ): Remember that we could do so as we have information on the individual contribution that they would choose if they would not be selected as leader.
} 
party. Increased salaries have a decreasing effect on attracting participants to take the role of thirdparty which is consistent with a crowding out effect of intrinsic motivations to lead. The effectiveness of higher salaries to induce more participants to take the role of the third party is limited in treatments where there is not counter punishment. Moreover in the treatment where the role of the third-party is anonymous, higher salaries are effective in inducing more participants to assume the role of the third-party in the Santal region but have no significant effect on participants in the Khasi region.

Table 3.8: Random effect regression on application by gender and society depending on wage

\begin{tabular}{lccccc}
\hline & \multicolumn{3}{c}{ Patriarchic } & & \multicolumn{2}{c}{ Matrilineal } \\
\cline { 2 - 3 } \cline { 5 - 6 } & Male & Female & & Male & Female \\
\hline Wage & $0.01^{*}$ & $0.02^{* * *}$ & & $0.02^{* *}$ & -0.00 \\
& $(0.00)$ & $(0.00)$ & & $(0.01)$ & $(0.00)$ \\
Wage & -0.00 & $-0.00^{* * *}$ & & $-0.00^{* *}$ & 0.00 \\
& $(0.00)$ & $(0.00)$ & & $(0.00)$ & $(0.00)$ \\
Constant & 0.21 & -0.17 & & -0.11 & $0.42^{* * *}$ \\
& $(0.11)$ & $(0.10)$ & & $(0.17)$ & $(0.13)$ \\
\hline Obs. & 707 & 811 & & 367 & 576 \\
Groups & 177 & 203 & & 92 & 144 \\
\hline
\end{tabular}

\subsubsection{Characteristics of participants who self-select in the role of third party}

Besides understanding how the organizational environment affects self-selection into the role of third party, it is interesting to understand who wants to take this role. In this section we compare the characteristics of the applicants. To consider the effect of our treatments on the decision to take the role of third party, we apply the following difference-in-differences model:

$$
\begin{aligned}
Y_{c} & =\beta_{0}+\beta_{1} A G R+\beta_{2} G P+\beta_{3} G R P A A \\
& +\beta_{4} A G R \text { apply }+\beta_{5} G P \text { apply }+\beta_{6} G R P A A * \text { apply }+€
\end{aligned}
$$

Where $\mathrm{Y}_{\mathrm{c}}$, refers to outcome of the characteristic $\mathrm{c}$ and apply is an indicator variable that takes the value of one for participants who volunteer to take the role of third party. Estimated coefficients $\beta_{0}$ to $\beta_{3}$ would capture differences in the characteristics of applicants across treatments or randomization biases, while the coefficients $\beta_{4}$ to $\beta_{6}$ give the measure how participants who apply differ across treatments. The first characteristic that we consider is differences in the level of 
cooperativeness of participants measured as the propensity to contribute to the public good. Remember, since participants took the contribution decision before the roles were assigned, this measure is incentivized.

Furthermore, we compare the age and the level of education of volunteers versus the non-volunteers. We find that in most of the treatments volunteers do not differ systematically from other participants. This result holds across genders and societies. The only exception is the treatment Giving Punishment in which participants who self-select into the role of third party are more cooperative. The only characteristic in which volunteers differ from non-volunteers is in age. In the patriarchal society, higher education is associated with a larger fraction of women who volunteer to take the role of third party under treatments giving punishment and giving and receiving under affirmative action, but decrease the fraction of female participants willing to assume that role in the giving and receiving punishment treatment. In contrasts, in the matrilineal society, men with at most primary education are more likely to take the role of the third party in the Giving and Receiving treatment but are less likely to do so in the giving punishment treatment and in the giving and receiving punishment with affirmative action. 
Table 3.9: Characteristics of Applicants vs. Not Applicants

\begin{tabular}{|c|c|c|c|c|}
\hline \multicolumn{5}{|l|}{ Contributions } \\
\hline & \multicolumn{2}{|c|}{ Patriarchic } & \multicolumn{2}{|c|}{ Matrilineal } \\
\hline & Male & Fernale & Male & Female \\
\hline Apply for leadership & $-0.801(2.547)$ & $1.671(2.407)$ & $-2.381(4.777)$ & $-3.314(2.442)$ \\
\hline Giving Public & $-3.280(2.582)$ & $4.995 * * *(1.826)$ & $-0.167(3.370)$ & $-2.772(2.671)$ \\
\hline Giving Receiving Anon & $2.731(2.147)$ & $3.659^{*}(1.921)$ & $-4.167(3.600)$ & $-0.322(2.332)$ \\
\hline Affirmative Action & $-1.474(2.092)$ & $-2.505(1.627)$ & $-1.947(2.535)$ & $-0.493(2.759)$ \\
\hline Apply for leadership $\times$ Giving Public & $8.181^{* *}(3.632)$ & $0.918(3.591)$ & $-4.452(7.004)$ & $7.692^{* *}(3.756)$ \\
\hline Apply for leadership $\times$ Giving Receiving Anon & $-4.143(3.795)$ & $-1.496(3.641)$ & $6.659(6.096)$ & $-0.114(3.549)$ \\
\hline Apply for leadership $\times$ Affirmative Action & $3.982(3.773)$ & $-2.290(3.115)$ & $-0.839(7.001)$ & $4.890(3.551)$ \\
\hline Constant & $19.57^{* * *}(1.476)$ & $16.79^{* * *}(0.842)$ & $17.67^{* * *}(1.663)$ & $15.67^{* * *}(1.997)$ \\
\hline$N$ & 164 & 172 & 88 & 134 \\
\hline \multicolumn{5}{|l|}{ Age } \\
\hline & \multicolumn{2}{|c|}{ Patriarchic } & \multicolumn{2}{|c|}{ Matrilineal } \\
\hline & Male & Fernale & Male & Fermale \\
\hline Apply for leadership & $-2.750(3.706)$ & $-1.500(3.626)$ & $2.051(4.644)$ & $5.775(9.280)$ \\
\hline Giving Public & $1.631(3.877)$ & $-5.230 *(2.606)$ & $2.885(4.756)$ & $-5.788(8.769)$ \\
\hline Giving Receiving Anon & $6.865 * *(3.410)$ & $-0.550(2.924)$ & $-7.315(4.796)$ & $-0.876(8.769)$ \\
\hline Affirmative Action & $4.129(3.566)$ & $-0.838(3.279)$ & $4.566(4.826)$ & $-3.957(8.399)$ \\
\hline Apply for leadership $\times$ Giving Public & $-1.988(5.266)$ & $3.817(5.050)$ & $-3.151(7.309)$ & $3.231(10.15)$ \\
\hline Apply for leadership $\times$ Giving Receiving Anon & $0.197(5.460)$ & $4.138(4.918)$ & $1.093(6.489)$ & $-10.75(10.11)$ \\
\hline Apply for leadership $\times$ Affirmative Action & $-3.129(6.016)$ & $-6.262(4.859)$ & $-1.233(9.688)$ & $-13.62(9.657)$ \\
\hline Constant & $33.75^{* * *}(2.271)$ & $36.60^{* * *}(2.049)$ & $28.62^{* * *}(3.900)$ & $35.60^{* * *}(8.223)$ \\
\hline$N$ & 154 & 150 & 70 & 100 \\
\hline \multicolumn{5}{|l|}{ Primary Education } \\
\hline & \multicolumn{2}{|c|}{ Patriarchic } & \multicolumn{2}{|c|}{ Matrilineal } \\
\hline & Male & Fernale & Male & Fermale \\
\hline Apply for leadership & $-0.123(0.119)$ & $-0.420 * * *(0.142)$ & $0.590^{*}(0.300)$ & $-0.250(0.226)$ \\
\hline Giving Public & $-0.152(0.103)$ & $-0.377^{* * *}(0.123)$ & $0.423(0.277)$ & $-0.188(0.234)$ \\
\hline Giving Receiving Anon & $0.207(0.134)$ & $-0.370^{* * *}(0.131)$ & $0.123(0.156)$ & $-0.216(0.229)$ \\
\hline Affirmative Action & $-0.109(0.105)$ & $-0.472 * * *(0.113)$ & $0.0140(0.102)$ & $0.0357(0.259)$ \\
\hline Apply for leadership $\times$ Giving Public & $0.209(0.157)$ & $0.277^{*}(0.157)$ & $-0.490(0.463)$ & $0.278(0.251)$ \\
\hline Apply for leadership $\times$ Giving Receiving Anon & $-0.0490(0.186)$ & $0.270(0.164)$ & $-0.679^{*}(0.347)$ & $0.382(0.255)$ \\
\hline Apply for leadership $\times$ Affirmative Action & $0.123(0.157)$ & $0.372 * *(0.149)$ & $-0.681^{* *}(0.307)$ & $0.164(0.319)$ \\
\hline Constant & $0.200^{* *}(0.0918)$ & $0.520 * * *(0.103)$ & $0.0769(0.0785)$ & $0.250(0.226)$ \\
\hline$N$ & 157 & 151 & 70 & 99 \\
\hline \multicolumn{5}{|l|}{ Secondary Education } \\
\hline & \multicolumn{2}{|c|}{ Patriarchic } & \multicolumn{2}{|c|}{ Matrilineal } \\
\hline & Male & Fernale & Male & Fermale \\
\hline Apply for leadership & $0.0923(0.173)$ & $0.280(0.173)$ & $-0.128(0.324)$ & $-0.125(0.316)$ \\
\hline Giving Public & $-0.0286(0.158)$ & $0.130(0.107)$ & $0.0385(0.304)$ & $0.187(0.287)$ \\
\hline Giving Receiving Anon & $-0.119(0.150)$ & $-0.0200(0.0960)$ & $0.138(0.221)$ & $0.121(0.277)$ \\
\hline Affirmative Action & $-0.0848(0.144)$ & $0.166(0.121)$ & $0.266(0.178)$ & $0.143(0.293)$ \\
\hline Apply for leadership $\times$ Giving Public & $0.00293(0.240)$ & $-0.280(0.222)$ & $-0.172(0.460)$ & $0.256(0.359)$ \\
\hline Apply for leadership $\times$ Giving Receiving Anon & $-0.103(0.235)$ & $-0.255(0.204)$ & $0.0838(0.404)$ & $-0.0790(0.362)$ \\
\hline Apply for leadership $\times$ Affirmative Action & $0.211(0.228)$ & $-0.0990(0.240)$ & $0.401(0.340)$ & $0.0821(0.412)$ \\
\hline Constant & $0.600^{* * *}(0.112)$ & $0.120^{*}(0.0668)$ & $0.462 * * *(0.147)$ & $0.500^{*}(0.261)$ \\
\hline$N$ & 157 & 151 & 70 & 99 \\
\hline
\end{tabular}

Note: This table reports a difference-in-differences estimation of the contribution levels, testing whether subjects who applied for the third party are different in their levels of contribution to the public good game. 


\subsection{Conclusion}

The negative association between women and leadership has been well established in the literature. (see the discussion in Chattopadhyay and Duflo, 2004; Duflo and Topalova, 2004; for statistics see Catalyst, 2011, 2012 ). Our study contributes to this literature by investigating the role of aversion to feedback and aversion to public roles in shaping societal differences in leadership choice. In this context, we also explore the role of affirmative action and wage increases to decrease gender gaps in leadership roles. Our findings reveal interesting heterogeneity on preferences across the two societies. In the patriarchal society, women lag significantly behind men in term of leadership selfselection, whereas the matrilineal society shows an opposite trend with female subjects being more likely to volunteer for leadership than men. Thus, in public Santal women are leadership averse, but Khasi women are not. Once we introduce anonymous leaders, Santal women reverse their preference for the leadership role significantly with more females now opting for leadership, and thereby eroding the gender gap. On the other hand, Khasi women display a significant decline in their leadership choice. This is contradictory to their previous choice and we argue that in the absence of social norms Khasi females feel less obliged to fulfill their leadership role. Under anonymity, we find no significant difference between Khasi men and women in terms of their selfselection into leadership. Investigating the role of feedback we do not find significant results, with the exception of Khasi men, who stand out to be significantly feedback averse. This result is not surprising, as in a matrilineal society, where the social norm does not force men to take up the leadership role, men will be more likely to shy away from leadership when they may receive feedback for their actions. However, we do not find a similar pattern among women in the patriarchal society.

Furthermore, we can draw important conclusions regarding affirmative action and its welfare implications. Our results show that affirmative action is an effective policy tool for promoting female leaders in patriarchal societies. In contrast, it has a detrimental effect on women's selfselection into leadership in matrilineal societies. In our experiment, Khasi women opted less often for leadership in response to affirmative action, which is contrary to policy expectations. We argue that this behavioral response might arise due to their preference for an equal status. Since they are already the empowered gender in the society, any preferential treatment may result in crowding out of women's willingness to act as leaders in matrilineal societies. Finally, we also looked at impact of higher monetary incentive on self-selection into leadership and we found that in general, wage 
increase has a positive impact on leadership choice. However, this relation is rather nonlinear in nature, i.e. with subsequent wage increase leadership participation increases but at a decreasing rate. From this finding we draw the conclusion that higher wages attracts more subjects to leadership role. Gradual wage increases is rather having a crowding out effect for both male and female as it often generates higher commitments towards the same job and thus higher sense of responsibility among the subjects resulting in crowding out of leadership motivation. This effect however is not so prominent for Khasi female who do not react much for small wage changes and only found to have significant participation increases for a sufficiently higher wage increase. This indicates that in societies where women shy away from leadership monetary incentive could bring them into the mainstream, however, higher incentive could infact crowd out female leaders as for same kind of leadership role they might assume higher remuneration generates higher responsibility. However, for powerful women, such as Khasi women, leadership participations are purely driven by leadership motivation and pecuniary motive might not result in higher participation in leadership by female subjects unless that motive is sufficiently high. 


\title{
4. Ethnicity and gender differences in risk and ambiguity attitude ${ }^{13}$
}

\begin{abstract}
We analyze gender difference in risk and ambiguity attitude of subjects across two different ethnicities that differ in the degree of female empowerment. Santal is a patriarchal tribe and Khasi is a matrilineal tribe with men and women being the social head in their respective societies. We compare subject's willingness to take up risk and ambiguity for themselves and on behalf of others. Besides we analyze the differences in risk and ambiguity attitude of subjects from these societies. Our findings show that women in both societies are significantly more risk averse, but not ambiguity averse. Patriarchal male and female are more risk averse in group risk than in individual risk but matrilineal subjects are not. Therefore, higher risk aversion in group is an ethnic trait among Santals. Comparing the between ethnicity differences we find that matrilineal subjects are more risk averse than patriarchal subjects. Regarding attitudes towards ambiguity, we did not find any gender or ethnicity differences.
\end{abstract}

Keyword: Risk attitude, Gender difference, Matrilineal society, Patriarchal society, Field experiment JEL Code: C93 D81 J15 J16

\footnotetext{
${ }^{13}$ I would like to thank Stephan Klasen, Marcela Ibanez and participants $11^{\text {th }}$ young economics workshop at University of Bologna for their valuable suggestions and comments. I would also like to thanks PRADAN and Voluntary Health Association of India for helping me to carry out the fieldwork.
} 


\subsection{Introduction}

Although women have made progress in attaining leadership roles in the work place, there has been much less discussion on how they actually lead. Since, leadership style affects welfare outcomes of institutions, investigating the impact of gender on leadership style could be of huge importance. Therefore, for a better understanding of these outcomes, gender differences in leadership style should emerge as a critical item in institutional economics research.

In this study we focus on two aspects of leadership style: in one the group leader makes decisions under risk and in the other under uncertainty, both affecting payoff of all members in the group. These types of decisions can range from choosing an investment decision for a fund subject to joint ownership to implementing new technologies. While the first decision would depend on the risk attitude of the leader, second one would relate more to the ambiguity attitude ${ }^{14}$.

Regarding gender differences in individual decisions making one of the stylized finding in the literature is that men and women differ in their propensities to engage in risky activities (for survey see Charness and Gneezy, 2012; Croson and Gneezy, 2009;Eckel and Grossman, 2008), with men tending to be less risk-averse than women. On the ambiguity front, evidence is rather mixed. There is some evidence on the existence of such differences (Jianakoplos and Bernasek, 1996, Barsky et.al., 1997, Powell and Ansic, 1997), but also some evidence against it (Schubert et.al., 1999).

We use Ellsberg (1961) two color game to investigate gender differences in leadership style with respect to risk and ambiguity aversion of subjects in individual and group decision making. In the individual game payoff is received individually; in the group game each subject's decision additionally determines the payoff of other group members. Therefore, in a way in the group game each subject behaves like an exogenously selected leader who decides on behalf of the group. There are few studies that have considered gender differences in risk taking behavior for others and in groups. For example, Ertac and Gurdal (2011) found that women are more risk-averse than men, in both individual and group context. Interestingly risk attitudes of women have no effect on whether they would like to decide for their group or not. In other words, women who take more risk and women who take less risk individually are equally likely to volunteer to be leaders. Daruvala (2007) shows that when subjects make

\footnotetext{
${ }^{14}$ In literature difference between risk and ambiguity is explained as one in which probability of a distribution is known and another in which there is uncertainty about the probability distribution (Ellsberg, 1961; Heath and Tversky, 1991; Camerer and Weber, 1992; Tversky and Kahneman; 1992; Fox and Tversky 1995; Fox and Weber, 2000).
} 
choices for others, they use combination of their own risk preferences and their predictions about the risk preferences of the target group. Both genders predict that women exhibit higher risk-aversion compared to men. Another strand of the literature has considered how groups make risky decisions through voting, compared to individuals. Harrison et al. (2013) use majority voting for group decisions and find that social risk, i.e. the risk taken in groups can be closely approximated by individual decisions. Shupp and Williams (2008) show that group discussion generates higher risk-aversion during decisions involving relatively higher risk. However, to the best of our knowledge such studies do not exist for ambiguity aversion.

In order to understand gender differences in leadership style we introduce leadership using an experimental treatment with subjects from two different social backgrounds. Experimental treatment refers to the above mentioned group treatment in which each subject acts as the exogenously selected leader; takes the decisions on behalf of the group; and her choice determines her group members' payoff. Any gender difference in the choices would then be attributable to the gender differences in leadership style in risk and ambiguity taking attitude. We also analyze if subjects behave differently in making group decisions than in individual decisions to understand the changes in the attitude while deciding for a group. Finally, we implemented the individual and group treatment with subjects from two different cultural background: Matrilineal Khasi and patriarchal Santal. In Khasi socio-economic power flows more in female line and in patriarchal Santal the cultural norms are similar to that of Hindu norms of preferring men. We argue that other than genetic factors, men and women could have different preferences because they are brought up differently. And if this is true, significant difference in gender and ethnicity differences are likely to occur.

Considering intra-society male-female power relations is not new in experimental economics, but evidence is still scarce. Gneezy et al., 2009 conducted an experiment with matrilineal Khasi in India and Patriarchal Massai in Tanzania to analyze gender differences in competitiveness. The subjects were given a choice to participate in ball-throwing game 10 times, either without competition, with each success yielding one dollar, or with competition with an anonymous subject from the same village, which yields three dollars in a win and no money at the loss. Their study found that while men are more inclined to compete among the Massai, Khasi women are more competitive than men and are even weakly more than Massai men. They also ran the investment risk experiment as control to their competition game and found no significant gender differences but significant ethnicity difference, with the matrilineal Khasi being less risk averse than the Massai. Andersen et al., 2013 choosing their 
subjects from matrilineal Khasi and patrilineal Kharbi investigate whether women are born less competitive or they become so through the process of socialization. By comparing the children from these tribes they found that the differences in competitiveness starts around puberty and most of the changes takes place only in patriarchal Kharbi where boys starts to become more competitive than girls. Recently, Gong et al. (2010) in a dictator game also found a reversed gender difference in the matrilineal Mosuo in China with men behaving more selflessly than women. Gong and Yang (2012) conducted another experiments on two different risk tasks with subjects from two ethnic groups, the matrilineal Mosuo and the patriarchal Yi in China. Their study concluded that women are more risk averse than men at both tasks within both ethnic groups. However, the gender gap is smaller in the Mosuo.

We find that women are more risk averse than men in both individual and group game within the two ethnicities. This is consistent with findings in most of the previous studies. Therefore, gender difference in risk attitude is a common phenomenon and does not depend on cultural background of the subjects. Additionally our study shows that there is an ethnicity difference in risk aversion with matrilineal subjects being more risk averse than the patriarchal subjects. Finally differences in group and individual behavior is found only among patriarchal subjects who behave more risk aversely in making group choices than in individual choices. On ambiguity aversion we do not find any evidence of either gender difference or ethnicity difference.

The rest of the paper is organized as follows: Section 4.2 describes the ethnicity background; Based on the existing literature, Section 4.3 describes experimental hypotheses; Section 4.4 presents the experimental design and procedure; Section 4.5 describes the data and the descriptive statistics; Section 4.6 discusses the results and interpretation and finally Section 4.7 concludes the study.

\subsection{Ethnicity background}

We implemented the same experiment in two different states of India as shown in the map with two different tribes, the Khasi and the Santal. While the structure of the Khasi is matrilineal the structure of the Santal is patriarchal. Comparing these societies will enable us disentangling impact of culture on risk and ambiguity attitude. 
Figure 4.1: Location of Khasi and Santal in the India

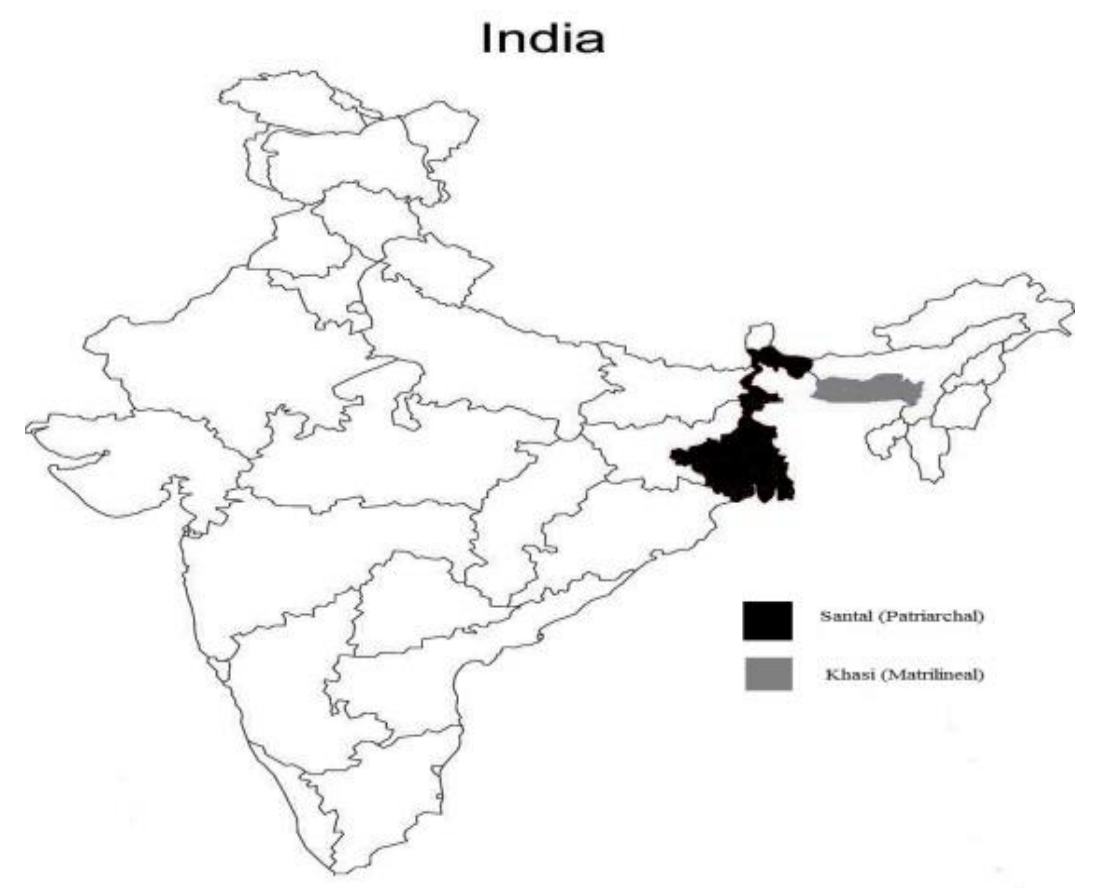

\subsubsection{Matrilineal Khasi}

The Khasi are located in the state of Meghalaya, a northeastern state of India (the gray region in the map). The tribal rules are considered to be matrilineal (Leonetti et al., 2004, Van Ham, 2000). Khasi women have the right to choose their own partner, cohabit and do not require male permission about the marriage. The institution of dowry does not exist; and it is common practice that the man moves to his wife's house after marriage. This stands in sharp contrast to the prevalent Indian system of marriage, in which wives always move to their husbands' house after marriage and there is an economically substantial dowry system (Bloch and Rao, 2002, Anderson, 2003). Khasi families are always organized around the female members (mostly around the grandmother who acts as the head of household); and a child always takes the mother's last name. Instead of the oldest son, the youngest daughter inherits all property establishing women power in the society. It is also an effective way to ensure that the youngest daughter is always around as a support to her parents in their old age. Interestingly, property rights for the youngest daughter and consequential old age support 
make son preference absent in the society. Incidence of female feticide and domestic violence against women is rare and intra-household access to health, education, and nutrition is equal among male and female family members (for more details see Andersen et al., 2008, 2013 Gneezy et al., 2009). With the Khasi, farming is the major economic activity and production is generally controlled by female members of the family. In addition to farming, women undertake all other economic activities and are often involved in trading with men from other societies.

\subsubsection{Patriarchal Santal}

The Santal, the largest tribal group of eastern India, are distributed over the states of Bihar, Orissa, and Tripura as well as in West Bengal, where our study was conducted (which is indicated by the black region in the map in Figure 1). The Santal society is patriarchal and has always avoided giving women equal decision rights and status than men. Santal customary law does not guarantee women inheritance rights in their parental property. They however have contingent rights to inheritance depending upon the circumstances. For instance, a common practice is to endow a married woman with some land in her natal village as a mean to provide financial support in case of unsuccessful marriage. However, according to the Santal Pargana Tenancy Act (SPTA), 1949, in absence of appropriate male heirs, the daughter inherits her father's land (Rao, 2005). Caring for parents in their old age is the responsibility of sons not of daughters. Once married, daughters are expected to spend their life under the supervision of their husbands or other elder men in the husband's family. A post experimental survey in our study revealed that female mobility even within the community is restricted and visiting parents, relatives, and friends by the women always requires taking permission from the adult male in the family. Low female mobility has also resulted in lower labor force participation by women. Similarly, expenditure decisions are mostly taken by men in the family, which is even triggered by the fact that in most household men are the major income earning members. Women's work and work experience differs significantly from those of men, and in some areas women are completely excluded from industrial work (Roy and Murry, 2013). The distribution of family resources among male and female members is unequal and even though women contribute significant amounts of labor to family farms, income earned mostly remains under the control of men. The Santal social norms are not an exception to the Hindu norms of favoring boys over girls, and son preference is prominent. 


\subsection{Hypotheses}

The previous literature on gender differences in risk and ambiguity aversion gives a direction regarding expected behavior in the experiment. This section aims at understanding the within and between society plausible differences and how far these differences differ in individual decisions making and group decision making. Accordingly we formulate the following hypotheses.

\subsubsection{Within ethnicity difference}

The first set of hypotheses we test are on the gender difference in risk and ambiguity aversion. The hypotheses we study regarding the gender difference pertains to the question why should women fare higher risk and ambiguity aversion than men? Apart from innate differences another suggested explanation could be that profit-maximizing behavior for women is to avoid risky and ambiguous choices because of backlash. For example, directive or authoritative leadership style is shown to work against women as compared to men leaders (Eagly, Makhijani and Klonsky, 1992; Eagly and Johnson, 1990). Bowles, Babcock and Lai (2007) in their study discussed how women are often penalized in job interviews for exhibiting higher negotiation skill than men. This explanation relates to the cultural environment in which women who behaves in a less feminine way are faced with social resistance than a man with similar behavioral traits.

On the other hand, existing studies addressing gender differences in altruism (Gong et al., 2010) and competition (Gneezy et al., 2009; Andersen et al., 2013) across matrilineal and patriarchal groups indicate that matrilineal women are more selfish and competitive than men. Since, women matrilineal society seems to behave substantially differently than the women from other societies we expect that the direction of gender differences generally observed in patriarchal set up is likely to reverse in Khasi with women being more risk and ambiguity loving than men.

Taking into consideration this literature we formulate different hypothesis on gender difference for our study groups.

Hypothesis1a. Women in the patriarchal tribe are significantly more risk and ambiguity averse than the men in individual and group decisions.

Hypothesis $1 \mathrm{~b}$. Women in the matrilineal tribe are significantly less risk and ambiguity averse than the men in individual and group decisions. 
Second hypothesis tests for the group versus individual risk and ambiguity attitude. In our set up, subject's decision on whether to be more risk and ambiguity averse (or loving) would depend on subject's perception about the group as well as her own preference (Daruvala, 2007) and how she holds herself responsible for the outcome (Chakravarty et al., 2011; Shutter, 2009; Bolton and Ockenfels, 2010). Depending on these variables then individual behavior might be significantly different when deciding on behalf of others. Since our design does not provide scope of in-group communication we expect subjects to opt more for the riskless option to avoid emotional hazards associated with no payoff to the group due to subjects' individual choices. Accordingly our hypothesis on group vs. individual decision making is that:

Hypothesis2. Deciding for the group makes individuals significantly more risk and ambiguity averse than deciding only for themselves.

\subsubsection{Between ethnicity differences}

A third set of hypotheses concerns differences between societies. The unique feature of our experiment is that it examines whether nurture has any observable impact on individuals personality traits on risk and ambiguity attitude. In contrast to the patriarchal society, since gender norms in matrilineal society favors women more than men, one might expect that the gender outcomes on risk and ambiguity aversion established so far in economic experiments will reverse in matrilineal society. Therefore, we expect women (men) in the matrilineal society have higher (lower) inclination towards risky and ambiguity choices than them in the patriarchal society. This is in line with the findings explained by Gong and Yang, 2012. Such behavioral reversal among matrilineal subjects has also been found by several other studies (Gneezy et al., 2009 on competitiveness, Gong et al., 2010 on transfers in ultimatum game). Therefore, we test the following hypotheses on between ethnicity differences.

Hypothesis3a. Matrilineal women will be significantly less risk and ambiguity averse than the patriarchal women in individual as well as group decisions.

Hypothesis $3 b$. Matrilineal men will be significantly more risk and ambiguity averse than Patriarchal men in individual as well as group decisions.

\subsection{Experimental design}

We elicited risk and ambiguity attitudes within the framework of the Ellsberg two-color choice task (Ellsberg, 1961). In the game each subject was asked to choose between a certain amount and a gamble which pays with equal probabilities either Rs. 50 or nothing. We use a 
simple gamble of drawing a ball form a bag containing balls of two different colors and guessing the color before the draw. Subject could earn Rs. 50 if they guessed the color of the ball otherwise nothing. Each subject makes this decision, i.e. either the gamble or the certain amount, 10 times with the same gamble but varying the value of the certain payment from Rs. 5 to Rs.50 (in an increasing order as shown in figure 4.2). Subjects are required to state their preference for all 10 options.

Figure 4.2: Choice list for risky and uncertain prospects for individual and group decision making

Decision sheet: Drawing ball for your (your group) from Bag A/B or a certain amount (Please put a cross against your preferred option)

\begin{tabular}{lllll} 
[1] Draw from bag A/B & O & or & O Rs. 5 for certain \\
[2] Draw from bag A/B & O & or & O Rs. 10 for certain \\
[3] Draw from bag A/B & O & or & O Rs. 15 for certain \\
[4] Draw from bag A/B & O & or & O Rs. 20 for certain \\
[5] Draw from bag A/B & O & or & O Rs. 25 for certain \\
[6] Draw from bag A/B & O & or & O Rs. 30 for certain \\
[7] Draw from bag A/B & O & or & O Rs. 35 for certain \\
[8] Draw from bag A/ B & O & or & O Rs. 40 for certain \\
[9] Draw from bag A/B & O & or & O Rs. 45 for certain \\
[10] Draw from bag A/B & O & or & O Rs. 50 for certain \\
\hline
\end{tabular}

Note: In the actual game subject saw one of the bags $\mathrm{A} / \mathrm{B}$ in the choice list and decisions were asked to make for themselves and for their group. Groups were kept secret throughout the game.

We use the same structure for the risk and ambiguity game, except that in risk game participants know that the bag (Bag A) contains exactly 10 yellow and 10 pink balls while in ambiguity game participants do not know the proportion of pink and yellow balls in the second bag (Bag B). In the ambiguity game we mixed 7 pink and 13 yellow balls.

Each subject plays risk and ambiguity games with individual and group payments. Altogether, therefore they filled up such choice list four times: Individual risk decision, group risk decision, individual ambiguity decision, and group ambiguity decision. The difference between the group and individual decision making is that in the individual case payoff is 
determined by subject's own choice, where as in the group case they remained responsible not only for their own payoff but also for the payoffs of others in the same group ${ }^{15}$. Each group is formed anonymously with four randomly chosen participants. While implementing the game each game was explained separately.

To control for the order effect we altered the order of the game. In some sessions subjects play the risk aversion game first and in others the ambiguity game. The four decisions were made one after another and only after the decision sheets are all filled up one was randomly selected for payment (described in details below)Therefore, there is no learning effect arising from the decision sheet filled up before.

\subsection{Payoffs}

The payment mechanism was clearly explained to the subjects before the game implementation. For payment, first, one of the bags i.e. risky or ambiguous prospects is randomly chosen. Second we made a random choice between individual game and group game. In case individual game is selected we selected one of the ten options randomly. On the other hand, if group option is chosen, one of the four members of the group is chosen to play for the whole group. Similarly as the individual game, one of the ten options were selected randomly for the group representatives. Depending on their decisions they either played the gamble or received the certain payoff instead.

\subsection{Attitude measurement}

We define measures of risk and ambiguity attitudes based on certainty equivalents (Wakker 2010, chapter 11; Sutter et al, 2013). As a measure of risk attitude $r$ we use

$$
r=1-C E R / \pi
$$

Where, $C E_{R}$ denotes the certainty equivalent of the risky prospect, $\pi$ is the lottery money. Values of $r$ smaller (larger) than 0.5 indicate risk loving (risk aversion), with risk neutrality for $r=0.5$. As a measure of ambiguity attitude we employ the value $a$,

$$
a=\left(C E_{R}-C E_{A}\right) /\left(C E_{R}+C E_{A}\right)
$$

\footnotetext{
${ }^{15}$ Few subjects made inconsistent choice by switching there preference several times. We took the first switching point to calculate certainty equivalence for them. In Santal inconsistency rates are Individual risk: 19.8\%, Group risk: $15.7 \%$, Individual ambiguity: $11.6 \%$, Group ambiguity: 14.3\%. In Khasi these rates are $34.3 \%, 34.3 \%, 38.5 \%$, and $39.4 \%$ respectively. These rates are comparable to the inconsistency rates found in other studies. For example Lammers, et al., 2006 find an inconsistency rate of 66.5\% in South Africa; Galarza, 2009 finds an inconsistency rate of 52\% in Peru; and Doerr et al., 2011 find an inconsistency rate of $39 \%$ in Ethiopia. For more see Charness and Viceisza, 2012.
} 
with $C E_{A}$ being the certainty equivalent of the ambiguous prospect. This measure ranges from -1 (extreme ambiguity loving) over 0 (ambiguity neutrality) to 1 (extreme ambiguity aversion). The larger the difference between the two certainty equivalents, the stronger is the ambiguity attitude, controlling for the absolute level of risk and ambiguity attitude. The normalization controls for the fact that, for example, a Rs.5 difference weighs more heavily for a subject who is relatively risk averse (e.g., with a certainty equivalent of Rs. 7.5) for the risky prospect) than for a subject who is relatively risk neutral (e.g., with a certainty equivalent of Rs27.5 for the risky prospect) ${ }^{16}$.

\subsection{Data and descriptive statistics}

The experiment was carried out between September 2012 and January 2013 in the states of Meghalaya and West Bengal. The research design is identical in the two states and was conducted in three districts of Meghalaya (Ribhoi, East Khasi Hills and Jaintia Hills) and one district in West Bengal (Purulia). 236 subjects in Meghalaya and 368 subjects in West Bengal participated in the experiment. We expect that our selection of ethnicities will provide contrasting behavioral differences by gender and by ethnicities. We conducted 40 sessions, 16 in the matrilineal society and 24 in the patriarchal society. Each session consists of three or four groups each with 4 members. Thus per session there were either 12 or 16 subjects, generating a sample of 604 subjects in total. Table 4.1 summarizes the number of participants by society and gender ${ }^{17}$.

Table 4.1: Number of subjects by gender and society

\begin{tabular}{llll}
\hline & Female & Male & Total \\
\hline Patriarchal & 198 & 170 & 368 \\
Matrilineal & 146 & 90 & 236 \\
Total & 344 & 260 & 604 \\
\hline
\end{tabular}

We first present information on socioeconomic characteristics collected in the postexperimental survey in Table 4.2. It includes information on subjects' gender, age, education, marital status, children, farm activity, bank account and group participation by ethnicity. 39\%

\footnotetext{
${ }^{16}$ Subjects who always chose the sure amount were classified as having a certainty equivalent that is halfway in between zero and the sure amount in the first row.

${ }^{17}$ In each session we recruited participants in advance to avoid selection bias. A post-experimental discussion revealed that selected participants agreed to take part either because of their pecuniary motives or social motives related to community development. In general, pecuniary motives ranked higher among Santal male participants, while social motives are a strong driver for most female participants.
} 
of the Khasi subjects and $46 \%$ of the Santal subjects are male. The sessions were either with a male majority or a female majority in the group, and we did not aim for gender equality in the groups on purpose to test whether gender composition has any impact on individual risk and ambiguity attitude. The average age of the subjects is 34.8 years in the case of the Santal sample and 31.08 years in the case of the Khasi sample. Splitting the sample by gender, we find that Khasi men are slightly younger (at a 5\% significance level) compared to Khasi women. Average household size in Khasi is 7 and in Santal 6. Furthermore, regarding our measure of education, we consider whether subjects have completed primary school and whether they have achieved an education level higher than primary. On the average, we find that $68 \%$ of Khasi women have obtained primary school or more than primary school. In the case of Santal women this is only the case for $46 \%$ of the subjects, indicating that Khasi women are on the average more educated than Santal women, especially so for the higher education. Comparing Khasi and Santal men with respect to their educational levels, we also find a small difference, but it is much less pronounced (no significant societal difference for men). With respect to within society gender differences, we find that at higher levels of education the gap between men and women is large in case of Santal (significant at less than $1 \%$ ), whereas it does not appear to be the case in Khasi. In Santal we find significantly more participation in group activities than in Khasi, both by male and female. However, in Santal while significantly more female take part in group activities than men, in Khasi we do not find within society gender difference in group participation. The major income-earning activity in the Santal society is farming, as indicated by $81 \%$ of the Santal subjects. Smallscale farming mostly involves family labor, whereby control remains in the hands of male adults. This is indicated by the fact that significantly (less than 1\%) higher number of Santal male reported their main occupation to be Farming than that by Santal female. Such control patterns have important welfare implications for women, whose economic power is limited. In the case of the Khasi subjects, the major income generating activity is also farming and female control over farming is higher than that by men. In contrast to the Santal society, farming-related decisions are mostly made by women. Finally looking at the gender difference in percentage of subjects having bank account we find that in Santal significantly (less than 10\%) more men have bank account than the women. However such difference does not exist is Khasi society. These results provide some descriptive evidence of the gender differences between the two societies. 
Table 4.2: Demographic characteristics of the subjects by society and gender

\begin{tabular}{|c|c|c|c|c|c|c|c|c|c|c|c|}
\hline & \multicolumn{4}{|c|}{ Matrilineal society } & \multicolumn{4}{|c|}{ Patriarchal society } & \multicolumn{3}{|c|}{ (Patriarchal- } \\
\hline & Pool & Female & Male & (Male- & Pool & Female & Male & (Male- & Pool & Female & Male \\
\hline & & $\begin{array}{c}\text { Mean } \\
(\mathrm{sd})\end{array}$ & & p-val & & \multicolumn{2}{|c|}{$\begin{array}{c}\text { Mean } \\
\text { (sd) }\end{array}$} & p-val & p-val & p-val & p-val \\
\hline Male & $\begin{array}{l}0.39 \\
(0.49)\end{array}$ & & & & $\begin{array}{l}0.46 \\
(0.50)\end{array}$ & & & & 0.06 & & \\
\hline Male majority & $\begin{array}{l}0.26 \\
(0.44)\end{array}$ & $\begin{array}{l}0.13 \\
(0.34)\end{array}$ & $\begin{array}{l}0.46 \\
(0.50)\end{array}$ & 0.00 & $\begin{array}{l}0.48 \\
(0.50)\end{array}$ & $\begin{array}{l}0.28 \\
(0.45)\end{array}$ & $\begin{array}{l}0.71 \\
(0.45)\end{array}$ & 0.00 & 0.00 & 0.00 & 0.00 \\
\hline Age & $\begin{array}{l}31.08 \\
(12.41)\end{array}$ & $\begin{array}{l}32.58 \\
(12.80)\end{array}$ & $\begin{array}{l}28.70 \\
(11.43)\end{array}$ & 0.02 & $\begin{array}{l}34.84 \\
(11.67)\end{array}$ & $\begin{array}{l}34.21 \\
(10.27)\end{array}$ & $\begin{array}{l}35.57 \\
(13.10)\end{array}$ & 0.26 & 0.00 & 0.19 & 0.00 \\
\hline Household size & $\begin{array}{l}7.03 \\
(3.01)\end{array}$ & $\begin{array}{l}7.25 \\
(3.14)\end{array}$ & $\begin{array}{l}6.66 \\
(2.76)\end{array}$ & 0.15 & $\begin{array}{l}6.18 \\
(2.97)\end{array}$ & $\begin{array}{l}5.98 \\
(2.68)\end{array}$ & $\begin{array}{l}6.42 \\
(3.28)\end{array}$ & 0.16 & 0.00 & 0.00 & 0.55 \\
\hline Primary education & $\begin{array}{l}0.17 \\
(0.37)\end{array}$ & $\begin{array}{l}0.12 \\
(0.33)\end{array}$ & $\begin{array}{l}0.23 \\
(0.42)\end{array}$ & 0.04 & $\begin{array}{l}0.17 \\
(0.38)\end{array}$ & $\begin{array}{l}0.18 \\
(0.38)\end{array}$ & $\begin{array}{l}0.17 \\
(0.38)\end{array}$ & 0.88 & 0.78 & 0.19 & 0.25 \\
\hline Higher than Primary & $\begin{array}{l}0.58 \\
(0.49)\end{array}$ & $\begin{array}{l}0.56 \\
(0.50)\end{array}$ & $\begin{array}{l}0.61 \\
(0.49)\end{array}$ & 0.49 & $\begin{array}{l}0.42 \\
(0.49)\end{array}$ & $\begin{array}{l}0.28 \\
(0.45)\end{array}$ & $\begin{array}{l}0.58 \\
(0.49)\end{array}$ & 0.00 & 0.00 & 0.00 & 0.68 \\
\hline Marriage & $\begin{array}{l}0.54 \\
(0.50)\end{array}$ & $\begin{array}{l}0.54 \\
(0.50)\end{array}$ & $\begin{array}{l}0.53 \\
(0.50)\end{array}$ & 0.83 & $\begin{array}{l}0.83 \\
(0.37)\end{array}$ & $\begin{array}{l}0.88 \\
(0.33)\end{array}$ & $\begin{array}{l}0.78 \\
(0.42)\end{array}$ & 0.01 & 0.00 & 0.00 & 0.00 \\
\hline Group Participation & $\begin{array}{l}0.60 \\
(0.49)\end{array}$ & $\begin{array}{l}0.62 \\
(0.49)\end{array}$ & $\begin{array}{l}0.58 \\
(0.50)\end{array}$ & 0.58 & $\begin{array}{l}0.85 \\
(0.35)\end{array}$ & $\begin{array}{l}0.97 \\
(0.16)\end{array}$ & $\begin{array}{l}0.71 \\
(0.45)\end{array}$ & 0.00 & 0.00 & 0.00 & 0.03 \\
\hline Farm activity & $\begin{array}{l}0.29 \\
(0.45)\end{array}$ & $\begin{array}{l}0.33 \\
(0.47)\end{array}$ & $\begin{array}{l}0.23 \\
(0.42)\end{array}$ & 0.09 & $\begin{array}{l}0.81 \\
(0.39)\end{array}$ & $\begin{array}{l}0.76 \\
(0.43)\end{array}$ & $\begin{array}{l}0.86 \\
0.34\end{array}$ & 0.01 & 0.00 & 0.00 & 0.00 \\
\hline Own bank account & $\begin{array}{l}0.56 \\
(0.50)\end{array}$ & $\begin{array}{l}0.57 \\
(0.50)\end{array}$ & $\begin{array}{l}0.53 \\
(0.50)\end{array}$ & 0.55 & $\begin{array}{l}0.33 \\
(0.48)\end{array}$ & $\begin{array}{l}0.30 \\
(0.48)\end{array}$ & $\begin{array}{l}0.38 \\
(0.49)\end{array}$ & 0.08 & 0.00 & 0.00 & 0.02 \\
\hline
\end{tabular}

\subsection{Results and interpretations}

Table 4.3 presents the mean risk and ambiguity aversion in group and individual decision makings by ethnicity and gender. Estimated risk attitude of matrilineal women in individual and group decisions are 0.61 and 0.6 respectively indicating that on average matrilineal women are risk averse. On the contrary matrilineal men behave more risk neutrally with estimated risk attitude 0.52 in individual decisions and 0.50 in group decisions. Interestingly, patriarchal women exhibits similar risk attitude as the matrilineal men with estimated individual risk attitude being 0.50 and group risk attitude being 0.56 . However, patriarchal men appear to be more risk loving in individual and group risk attitude ( 0.36 and 0.42 in individual and group decisions respectively). Therefore, in the two ethnicities we find that on average, women are significantly less risk taking than men in both individual and group decision making. One might expect the gender gap to reverse in the matrilineal society as 
found in the competition game of Gneezy et al., 2009 and dictator game of Gong et al., 2012. Our study, on the contrary shows that higher risk aversion exists even among matrilineal women indicating that risk aversion among women is rather a general phenomenon and does not depend on ethnic norms. We further argue that since we find that the gender difference in risk attitude not only in individual decisions but also in group decisions it could be inferred that the women are risk averse not only in individual choices but also when they are in leading roles (exogenously selected) compared to their male counterparts in.

Looking at differences in risk aversion between individual and group decisions, we find no significant difference in risk and ambiguity attitude in the matrilineal society. But in patriarchal society both male and female subjects are significantly more risk averse in groups than they are individually. Therefore, hypothesis 2 is supported only for risk aversion in patriarchal society (for men and women) ${ }^{18}$.

Finally, no significant gender difference or differences individual in group choices could be established in ambiguity attitude of the subjects from these two societies (reported in the last three columns in Table 4.3). Therefore, we find evidence to support hypothesis 1a only for risk aversion and hypothesis $1 \mathrm{~b}$ is rejected for risk and ambiguity.

Table 4.3: risk and ambiguity aversion by gender and ethnicity

\begin{tabular}{|c|c|c|c|c|c|c|c|}
\hline & & IRA & GRA & IRA-GRA & IAA & GAA & IAA-GAA \\
\hline & Male & 0.52 & 0.5 & $0.02(0.39)$ & 0.00 & 0.04 & $-0.04(0.16)$ \\
\hline \multirow[t]{2}{*}{ Matrilineal } & Female & 0.61 & 0.6 & $0.01(0.49)$ & -0.04 & 0.00 & $-0.04(0.62)$ \\
\hline & Male & 0.36 & 0.42 & $-0.07(0.00)^{* * *}$ & 0.08 & 0.08 & $0.00(0.55)$ \\
\hline Patriarchal & Female & 0.5 & 0.56 & $-0.06(0.00)^{* * *}$ & 0.08 & 0.08 & $0.00(0.51)$ \\
\hline \multicolumn{8}{|c|}{ Gender difference within ethnicities } \\
\hline & & $-0.09 * *$ & $-0.10 * *$ & & 0.04 & 0.04 & \\
\hline & Matrilineal & $(0.03)$ & $(0.03)$ & & $(0.57)$ & $(0.72)$ & \\
\hline & & $-0.14 * * *$ & $-0.14 * * *$ & & 0.00 & 0.00 & \\
\hline Male-Female & Patriarchal & $(0.00)$ & $(0.00)$ & & $(0.74)$ & $(0.71)$ & \\
\hline
\end{tabular}

Note: Probabilities are reported in the parentheses are from Wilcoxon ranksum tests. IRA: Individual risk aversion, GRA: Group risk aversion, IAA: Individual ambiguity aversion, GAA: Group ambiguity aversion.

Next, we attempt to analyze the gender differences that we observe in Table 4.3 in a regression framework with and without socio-economic controls described in Table 4.2.

\footnotetext{
${ }^{18}$ Additionally, we also tested for gender differences in ethnicity differences and gender differences of group minus individual differences in risk and ambiguity attitude. These differences are all insignificant.
} 
Regression tables are reported in the appendix. The model we estimate for individual and group risk and ambiguity attitudes is the following (individual subscripts are deleted).

$$
L=\beta_{0}+\beta_{1} \text { Male }+\beta_{2} \text { Matrlineal }+\beta_{3} \text { Matrilineal } * \text { Male }+\lceil\text { Controls }+€
$$

Gender differences are given by

Matrilineal society: $\beta_{1}+\beta_{3}$ and

Patriarchal society: $\beta_{1}$

Societal differences are given by,

Male: $\beta_{2}+\beta_{3}$ and

Female: $\beta_{2}$

Table 4.4: Within ethnicity gender differences (male-female) in risk and ambiguity attitude

\begin{tabular}{lllll}
\hline & \multicolumn{2}{l}{ With socio-economic controls } & \multicolumn{2}{l}{ Without socio-economic controls } \\
\hline \hline IRA & Matrilineal & Patriarchal & Matrilineal & Patriarchal \\
GRA & $-0.10(0.08)^{*}$ & $-0.17(0.00)^{* * *}$ & $-0.10\left((0.05)^{* *}\right.$ & $-0.21(0.00)^{* * *}$ \\
IAA & $-0.08(012)$ & $-0.16(0.00)^{* * *}$ & $-0.09(0.05)^{* *}$ & $-0.21(0.00)^{* * *}$ \\
GAA & $-0.02(0.68)$ & $-0.04(0.37)$ & $0.01(0.88)$ & $-0.02(0.68)$ \\
& $0.02(0.73)$ & $-0.01(0.87)$ & $-0.002(0.96)$ & $0.02(0.52)$
\end{tabular}

Note: Probability values of differences are reported in the parentheses; No significant differences could be found in group vs. individual differences. The numbers are negative because men are more risk and ambiguity taking than women in these two societies. Individual minus group differences in gender differences are never significant

Table 4.4 presents the estimates of gender differences by ethnicity with and without socioeconomic controls. With and without socio-economic controls, women from the two societies are significantly less risk taking than men in individual choice. In group decisions also this gender difference persists in patriarchal society, but vanishes in matrilineal society once the socio-economic variables are included as controls in regression. By and large these results are consistent with the finding in Table 4.3, indicating that gender difference in risk attitude with women being less inclined towards risky choices is an innate gender trait and is not influenced by cultural norms, and such difference exists even among the exogenously selected leaders in the group game. Again ambiguity attitudes do not show any gender differences with and without the controls.

Table 4.5 presents ethnicity differences in risk and ambiguity attitude by gender with and without socio-economic controls. Our result shows that matrilineal subjects (men and women) 
are significantly less risk taking than patriarchal men and women subjects in individual and group decisions. Therefore, these findings do not reflect what we initially anticipated: Khasi women and Santal men will be more risk loving. Instead we find an ethnicity difference in risk taking behavior with Khasi subjects being more risk averse. Therefore, hypothesis $3 \mathrm{a}$ is rejected and hypothesis $3 \mathrm{~b}$ is accepted only for risk attitude. We argue that such ethnic difference in risk attitude might occur due to differences in exposure to economic and environmental risks faced by these communities. Economic development of the entire north east India (where the Khasi people resides) has been historically lagging behind compared to the state of West Bengal (where the Santals are located). According to the 11th Five Year Plan (2007a, 2007b) despite huge investments (\$1.5 billion), the infrastructure development in the northeast region has remained poor. Due to low penetration of financial institutions, access to credit is limited, as a result industrial and economic activities remained slow. These have led to a lag of development in most of the northeast region in India. Furthermore, north eastern part of India which is characterized by diverse climatic regimes, high incidence of drought or flood and often experience environmental shocks affecting agricultural production (Ravindranath et al, 2011). Such economic and environmental could be one critical factor determining the lower risk taking attitude by Khasi subjects ${ }^{19}$.

Table 4.5: Ethnicity (matrilineal -patriarchal) differences in risk and ambiguity attitude

\begin{tabular}{lllll}
\hline & \multicolumn{2}{l}{ With socio-economic controls } & \multicolumn{2}{l}{ Without socio-economic controls } \\
\hline \hline IRA & Male & Female & Male & Female \\
GRA & $0.22(0.00)^{* * *}$ & $0.15(0.02)^{* *}$ & $0.20(0.00)^{* * *}$ & $0.09(0.07)^{*}$ \\
IAA & $0.21(0.00)^{* * *}$ & $0.13(0.02)^{* *}$ & $0.19(0.00)^{* * *}$ & $0.08(0.08)^{*}$ \\
GAA & $-0.07(0.31)$ & $-0.08(0.20)$ & $-0.01(0.82)$ & $-0.03(0.52)$ \\
& $-0.06(0.34)$ & $-0.08(0.22)$ & $-0.03(0.61)$ & $-0.003(0.95)$
\end{tabular}

Note: Probability values of differences are reported in the parentheses; No significant differences could be found in group vs. individual differences. Individual minus group differences in ethnicity differences are never significant

Looking at the socio economic characteristics (reported in Table 4.6 in appendix) we observe that age has a negative and nonlinear correlation with individual ambiguity. Higher household size increases risk aversion in groups; primary education is negatively correlated with risk aversion in groups and group participation in real life is also correlated positively with risk aversion in groups and individual choices. Having a bank account makes individual more

\footnotetext{
${ }^{19}$ There are a few studies that have analyzed negatice association between shocks and risk taking behaviuor, e.g., Yesuf and Bluffstone (2009); Guiso and Paiella (2008); Gloede, Mankauff, Waibel, 2013
} 
ambiguity loving. Finally, higher male presence in the session is found increase group risk aversion and individual ambiguity aversion.

\subsection{Summary and conclusion}

Using Ellsberg two color choice experiments we elicit risk and ambiguity attitude of 604 subjects to investigate whether there is any gender difference in leadership style. There are two specific contributions of this study. First, in our setup each subject is asked to decide for themselves and then on behalf of their group. In the first case payoff is received individually and in the second subject's decision also determined group members' income. Thus, in the second scenario we allow each subject to behave as exogenously determined leader, taking decision on behalf of the group and being responsible also for the outcome. Our objective is to examine whether risk, ambiguity attitudes vary significantly depending on who bears the consequences of a particular choice. Second, we attempt to understand if gender and leadership norms of a society have any impact on risk and ambiguity. To achieve our objective we implemented the same experiment with subjects from two different ethnicities in India- one is a matrilineal tribe known as Khasi with women being the leading gender and another is a patriarchal tribe known as Santal with men being the head of the society. We believe that such choice of ethnicities with different power balance would help us to understand the role of norms in shaping risk and ambiguity preference of the subjects.

Our first result suggests a gender difference in risk taking attitude is rather a general trait: women are more risk averse than men in both the ethnicities i.e. irrespective of cultural context women are more risk averse in Santal and Khasi. Second, such difference exists even when subjects are deciding for their group. Therefore, even when subjects are acting as leaders (exogenously selected) the gender difference persists. This is consistent with the general finding in the investment decision but different from Gneezy et al.'s (2009) observation of no gender difference in the individual risk decision in both the matrilineal Khasi and the patriarchal Maasai. Third, on the difference between individual and group decisions we find that patriarchal subjects (men and women) are significantly more risk averse in group choices than they are individually; but similar could not be established for matrilineal subjects. Finally, we find that an ethnicity difference exists in risk attitude of the subjects from these two ethnicities with matrilineal subjects being more risk averse than the patriarchal subjects in group as well as individual choices. We argue this might occur due to higher exposure of Khasi subjects to economic and environmental shocks. 


\section{Biblography}

Adhikari, B., \& Lovett, J. C. (2006). Institutions and collective action: does heterogeneity matter in community-based resource management?. The Journal of Development Studies, 42(03), 426-445.

Agarwal, B. (2001). Participatory exclusions, community forestry, and gender: An analysis for South Asia and a conceptual framework. World development,29(10), 1623-1648.

Andersen, S., Bulte, E., Gneezy, U., \& List, J. A. (2008). Do women supply more public goods than men? Preliminary experimental evidence from matrilineal and patriarchal societies. The American Economic Review, 376-381.

Andersen, S., Ertac, S., Gneezy, U., List, J. A., \& Maximiano, S. (2013). Gender, Competitiveness, and Socialization at a Young Age: Evidence From a Matrilineal and a Patriarchal Society. Review of Economics and Statistics,95(4), 1438-1443.

Anderson, S. (2003). Why Dowry Payments Declined with Modernization in Europe but Are Rising in India. Journal of Political Economy, 111(2).

Arbak, E., \& Villeval, M. C. (2013). Voluntary leadership: motivation and influence. Social Choice and Welfare, 40(3), 635-662.

Asiedu, E., \& Ibanez, M. (2014). The weaker sex? Gender differences in punishment across matrilineal and patriarchal socienties (No. 30). GlobalFood Discussion Papers.

Balafoutas, L., \& Nikiforakis, N. (2012). Norm enforcement in the city: a natural field experiment. European Economic Review, 56(8), 1773-1785.

Bamrud, J and Calderon, G., 2012. Latin America: Few Female CEOs. Latin Business Chronicle (March 8, 2012)

Banerji, A., Mahtani, S., Sealy, R., Vinnicombe, A.; Standard Chartered Bank: Women on Corporate Boards in India 2010 (UK: Cranfield School of Management, 2010), in http://www.communitybusiness.org/images/cb/publications/2010/WOB_India.

Barber, B. M., \& Odean, T. (2001). Boys will be boys: Gender, overconfidence, and common stock investment. The Quarterly Journal of Economics, 116(1), 261-292.

Barham, J., \& Chitemi, C. (2009). Collective action initiatives to improve marketing performance: Lessons from farmer groups in Tanzania. Food Policy,34(1), 53-59.

Barsky, R. B., Juster, F. T., Kimball, M. S., \& Shapiro, M. D. (1997). Preference parameters and behavioral heterogeneity: An experimental approach in the health and retirement study. The Quarterly Journal of Economics, 112(2), 537-579.

Bass, B. M. (1985). Lead ership and performance beyond expectations. New York: Free Press.

Basu, K. (2006). Gender and Say: a Model of Household Behaviour with Endogenously Determined Balance of Power. The Economic Journal,116(511), 558-580.

Bernard, T., \& Spielman, D. J. (2009). Reaching the rural poor through rural producer organizations? A study of agricultural marketing cooperatives in Ethiopia. Food Policy, 34(1), 60-69.

Bianchi, T. (2002). Leaders and intermediaries as economic development agents in producer's associations'. Group behavior and development: Is the market destroying cooperation, 105-124. 
Blackden, C.M. and C. Bhanu (1999). Gender, Growth, and Poverty Reduction: Special Program of Assistance for Africa, 1998 Status Report on Poverty in Sub-Saharan Africa', World Bank Technical Paper, Washington DC: World Bank.

Bloch, F., \& Rao, V. (2002). Terror as a bargaining instrument: A case study of dowry violence in rural India. American Economic Review, 1029-1043.

Bolton, G. E., \& Ockenfels, A. (2010). Betrayal aversion: Evidence from brazil, china, oman, switzerland, turkey, and the united states: Comment. The American Economic Review, 628-633.

Bosman, R., \& Van Winden, F. (2002). EMOTIONAL HAZARD IN A POWER-TO-TAKE EXPERIMENT. The Economic Journal, 112(476), 147-169.

Bowles, H. R., Babcock, L., \& Lai, L. (2007). Social incentives for gender differences in the propensity to initiate negotiations: Sometimes it does hurt to ask. Organizational Behavior and Human Decision Processes, 103(1), 84-103.

Bradley, K., \& Khor, D. (1993). Toward an integration of theory and research on the status of women. Gender \& Society, 7(3), 347-378.

Brandts, J., \& Cooper, D. J. (2006). A change would do you good.... An experimental study on how to overcome coordination failure in organizations. The American Economic Review, 669-693.

Brandts, J., \& Cooper, D. J. (2007). IT'S WHAT YOU SAY, NOT WHAT YOU PAY: AN EXPERIMENTAL STUDY OF MANAGER-EMPLOYEE RELATIONSHIPS IN OVERCOMING COORDINATION FAILURE. Journal of the European Economic Association, 5(6), 1223-1268.

Browning, M.,\& Chiappori, P.-A. (1998). Efficient intra-household allocation: a characterisation and tests. Econometrica, 66(6), 1241-1278.

Bruttel, L., \& Fischbacher, U. (2013). Taking the initiative. What characterizes leaders?. European Economic Review, 64, 147-168.

Camerer, C. and M. Weber (1992). Recent developments in Modeling Preferences: Uncertainty and Ambiguity. Journal of Risk and Uncertainty, 5 (4), pp. 325-370.

Carpenter, J. P. (2007). Punishing free-riders: How group size affects mutual monitoring and the provision of public goods. Games and Economic Behavior,60(1), 31-51.

Catalyst Census, 2011 : FORTUNE 500. Women Board Directors. , pp.2010-2011.

Catalyst. Women on Boards. New York: Catalyst, 2012. http://www.catalyst.org/publication/433/women-on-boards

Cepeda E. L., \& Baron, J. (2012). Educational segregation and the gender wage gap for recent college graduates in Colombia.

Chakravarty, S., Harrison, G. W., Haruvy, E. E., \& Rutström, E. E. (2011). Are You Risk Averse over Other People's Money?. Southern Economic Journal,77(4), 901-913.

Charness, G., \& Gneezy, U. (2012). Strong evidence for gender differences in risk taking. Journal of Economic Behavior \& Organization, 83(1), 50-58.

Charness, G., \& Viceisza, A. (2012). Comprehension and risk elicitation in the field: Evidence from rural Senegal. mimeo. 
Chattopadhyay, R., \& Duflo, E. (2004). Women as policy makers: Evidence from a randomized policy experiment in India. Econometrica, 72(5), 1409-1443.

Chen, L. J., 2010, 'Do Gender Quotas Influence Women's Representation and Policies?', The European Journal of Comparative Economics, vol. 7, no. 1, pp. 13-60

Chiappori, P. A. (1988). Rational household labor supply. Econometrica: Journal of the Econometric Society, 63-90.

Chiappori, P. A. (1992). Collective labor supply and welfare. Journal of political Economy, 100(3), 437.

Chiappori, P. A., Fortin, B., \& Lacroix, G. (2002). Marriage market, divorce legislation, and household labor supply. Journal of political Economy, 110(1), 37-72.

Chowdury, S. (2006). Access to a telephone and factor market participation of rural households in Bangladesh. Journal of Agricultural Economics, 57(3), 563-576.

Clark, K., \& Sefton, M. (2001). Repetition and signalling: experimental evidence from games with efficient equilibria. Economics Letters, 70(3), 357-362.

Corporae Women Directors International. Women board Directors of the Latin Trade 100 companies: Key findings.

Croson, R., \& Gneezy, U. (2009). Gender differences in preferences. Journal of Economic literature, 448-474.

Dada, L. A.(2007), The African export industry: what happened and how can it be revived?, Case Study on the Cameroonian cocoa sector. FAO, Agricultural Management, Marketing and Finance, Working Document 215, Rome: FAO

Daruvala, D.(2007). Gender, risk and stereotypes. Journal of Risk and Uncertainty 35, 265283.

De Cremer, D., \& van Knippenberg, D. (2005). Cooperation as a function of leader selfsacrifice, trust, and identification. Leadership \& Organization Development Journal, 26(5), 355-369.

De Janvry, A., \& Sadoulet, E. (2006). Making conditional cash transfer programs more efficient: designing for maximum effect of the conditionality. The World Bank Economic Review, 20(1), 1-29.

Doerr, U., Toman, O. M., \& Schmidt, U. (2011). Overconfidence and risk management of Ethiopian farmers. Working paper.

Duflo, E. \& Udry, C. (2004). Intrahousehold resource allocation in Cote d'Ivoire: Social norms, separate accounts and consumption choices. NBER working papers no. 10498. National Bureau of Economic Research, Inc.

Duflo, E. (2011). Women's empowerment and economic development (No. w17702). National Bureau of Economic Research.

Duflo, E., \& Topalova, P. (2004). Unappreciated Service: Performance, Perceptions, and Women: Leaders in India. Massachusetts institute of technology (MIT). Department of economics.

Duguma, B., Gockowski, J., Bakala, J.(2001). Smallholder cacao (Theobroma cacao Linn.) cultivation in agroforestry systems of west and central Africa: challenges and opportunities. Agroforest. Syst. 51, 177-188. 
Dweck, C. S. (2000). Self-theories: Their role in motivation, personality, and development. Psychology Press.

Eagly, A. H., \& Johnson, B. T. (1990). Gender and leadership style: A metaanalysis. Psychological bulletin, 108(2), 233.

Eagly, A. H., \& Karau, S. J. (2002). Role congruity theory of prejudice toward female leaders. Psychological Review, 109, 573-598.

Eagly, A. H., Makhijani, M. G., \& Klonsky, B. G. (1992). Gender and the evaluation of leaders: A meta-analysis. Psychological bulletin, 111(1), 3.

Eckel, C. C., \& Grossman, P. J. (2002). Sex differences and statistical stereotyping in attitudes toward financial risk. Evolution and Human Behavior,23(4), 281-295.

Eckel, C. C., \& Grossman, P. J. (2008). Men, women and risk aversion: Experimental evidence. Handbook of experimental economics results, 1(7), 1061-73.

Eckel, Catherine C. and and Philip J. Grossman, 2002, "Sex differences and statistical stereotyping in attitudes towards financial risk," Evolution and Human Behavior 23:281295.

Ellsberg, D. (1961). Risk, Ambiguity and the Savage Axioms,' Quarterly Journal of Economics, 75, pp. 643-669.

Ertac, S., \& Gurdal, M. Y. (2012). Deciding to decide: Gender, leadership and risk-taking in groups. Journal of Economic Behavior \& Organization, 83(1), 24-30.

Fafchamps, M., \& Quisumbing, A. R. (2002). Control and ownership of assets within rural Ethiopian households. Journal of Development Studies, 38(6), 47-82.

FAO. (2011). Women in agriculture: Closing the gender gap for development. Rome: Food and Agriculture Organization.

Fehr, E., \& Fischbacher, U. (2004). Third-party punishment and social norms.Evolution and human behavior, 25(2), 63-87.

Fehr, E., \& Gächter, S. (2002). Altruistic punishment in humans. Nature,415(6868), 137-140.

Fletschner, D. (2009). Rural women's access to credit: market imperfections and intrahousehold dynamics. World Development, 37(3), 618-631.

Fletschner, D., \& Mesbah, D. (2011). Gender Disparity in Access to Information: Do Spouses Share What They Know?. World Development, 39(8), 1422-1433.

Fox, C. R., \& Tversky, A. (1995). Ambiguity aversion and comparative ignorance. The quarterly journal of economics, 110(3), 585-603.

Fox, C. R., \& Weber, M. (2002). Ambiguity aversion, comparative ignorance, and decision context. Organizational Behavior and Human Decision Processes,88(1), 476-498.

Galarza, F. (2009). Choices under risk in rural Peru. Munich Personal RePec Archive Working Paper 17708, Munich.

Gertler, P. (2004). Do conditional cash transfers improve child health? Evidence from PROGRESA's control randomized experiment. American economic review, 336-341.

Glöckner, A., Irlenbusch, B., Kube, S., Nicklisch, A., \& Normann, H. T. (2011). Leading With (Out) Sacrifice? A Public-Goods Experiment With A Privileged Player. Economic Inquiry, 49(2), 591-597. 
Gloede, O., Menkhoff, L., \& Waibel, H. (2013). Shocks, individual risk attitude, and vulnerability to poverty among rural households in Thailand and Vietnam. World Development.

Gneezy, U., Leonard, K. L., \& List, J. A. (2009). Gender differences in competition: Evidence from a matrilineal and a patriarchal society.Econometrica, 77(5), 1637-1664.

Gneezy, U., Niederle, M., \& Rustichini, A. (2003). Performance in competitive environments: Gender differences. The Quarterly Journal of Economics, 118(3), 1049-1074.

Gockowski, J, Mva, J, Oduwole, S \& Nyemeck, BJ, (2008). Institutional Innovation in the credit, input, and cocoa markets of West Africa. STCP (Sustainable Tree Crop Program) Working Paper Series, Issue 8, International Institute of Tropical Agriculture, Accra, Ghana.

Gockowski, J. (2008). Post-liberalization interlinkage in the credit and cocoa markets of West Africa. Draft in progress. STCP-IITA. (Sustainable Tree Crop Program - International Institute of Tropical Agriculture), Accra, Ghana.

Gong, B., \& Yang, C. L. (2012). Gender differences in risk attitudes: Field experiments on the matrilineal Mosuo and the patriarchal Yi. Journal of Economic Behavior \& Organization, 83(1), 59-65.

Gong, B., Yan, H., \& Yang, C. L. (2010). Gender Differences in the Dictator Experiment: Evidence from the Matrilineal Mosuo and the Patriarchal Yi.Available at SSRN 1655689.

Guiso, L., \& Paiella, M. (2008). Risk aversion, wealth, and background risk.Journal of the European Economic association, 6(6), 1109-1150.

Gurerk, O., Irlenbusch, B., Rockenbach, B., (2006). The competitive advantage of sanctioning institutions. Science 312, 108-111.

Güth, W., Levati, M. V., Sutter, M., \& Van Der Heijden, E. (2007). Leading by example with and without exclusion power in voluntary contribution experiments. Journal of Public Economics, 91(5), 1023-1042.

Haigner, S. D., \& Wakolbinger, F. (2010). To lead or not to lead: Endogenous sequencing in public goods games. Economics Letters, 108(1), 93-95.

Harrison, G. W., Lau, M. I., Rutström, E. E., \& Tarazona-Gómez, M. (2013). Preferences over social risk. Oxford Economic Papers, 65(1), 25-46.

Hashemi, S. M., Schuler, S. R., \& Riley, A. P. (1996). Rural credit programs and women's empowerment in Bangladesh. World development, 24(4), 635-653.

Heath, C., \& Tversky, A. (1991). Preference and belief: Ambiguity and competence in choice under uncertainty. Journal of risk and uncertainty, 4(1), 5-28.

Henrich, J., R. McElreath, A. Barr, J. Ensminger, C. Barrett, A. Bolyanatz, J. C.,Cardenas, M. Gurven, E. Gwako, N. Henrich, et al. 2006. "Costly punishment across human societies." Science, 312(5781): 1767-1770.

Hermalin, B. E. (1998). Toward an economic theory of leadership: Leading by example. American Economic Review, 1188-1206.

Hurwitz, M. S., \& Lanier, D. N. (2008). Diversity in state and federal appellate courts: Change and continuity across 20 years. Justice System Journal, 29(1), 47-70. 
Ibanez, M., \& Schaffland, E. (2013). The Effect of Outside Leaders on the Performance of the Organization: An Experiment (No. 149). Courant Research Centre: Poverty, Equity and Growth-Discussion Papers.

Ibanez, M., Czermak, S., \& Sutter, M. (2009). Searching for a better deal-On the influence of group decision making, time pressure and gender on search behavior. Journal of Economic Psychology, 30(1), 1-10.

Jianakoplos, N. A., \& Bernasek, A. (1998). Are women more risk averse?.Economic inquiry, 36(4), 620-630.

Jones, C. (1983). The mobilization of women's labor for cash crop production: A game theoretic approach. American Journal of Agricultural Economics, 65(5), 1049-1054.

Kabeer, N. (2001). Resources, Agency, Achievements: Reflections on the Measurement of Women's Empowerment. in Discussing Women's Empowerment - Theory and Practice, ed. A. Sisask, Sida Studies No. 3, Swedish International Development Agency, Stockholm, pp. 17-59.

Kabeer, N., 1994. Reversed Realities: Gender Hierarchies in Development Thought. Verso, London.

Kenworthy, L. (1997). Civic engagement, social capital, and economic cooperation. American Behavioral Scientist, 40(5), 645-656.

Kherallah, M., Delgado, C. L., Gabre-Madhin, E. Z., Minot, N., \& Johnson, M. (2002). Reforming agricultural markets in Africa (No. 38). International Food Policy Research Institute (IFPRI).

Klasen, S. (1998). Marriage, bargaining, and intrahousehold resource allocation: Excess female mortality among adults during early German development, 1740-1860. The Journal of Economic History, 58(02), 432-467.

Kodama, Y. (2007). New role of cooperatives in Ethiopia: the case of Ethiopian coffee farmers cooperatives. African study monographs. Supplementary issue.,35, 87-108.

Kray, L. J., Galinsky, A.,\& Thompson, L. (2002). Reversing the gender gap in negotiations: An exploration of stereotype regeneration. Organizational Behavior and Human Decision Processes, 87, 386-410.

Kray, L. J., Thompson, L., \& Galinsky, A. (2001). Battle of the sexes: Gender stereotype confirmation and reactance in negotiations. Journal of Personality and Social Psychology, 80, 942-958.

Kumase, W. A. N., Bisseleua, H., \& Klasen, S. (2010). Opportunities and constraints in agriculture: A gendered analysis of cocoa production in Southern Cameroon (No. 27). Courant Research Centre: Poverty, Equity and Growth-Discussion Papers.

Lammers, J., Lau, M., \& Verbon, H. (2006, June). Perceived HIV-contamination risk, risk aversion and time preferences (A Laboratory Experiment in South Africa). In Conference paper.

Leonetti, D. L., Nath, D. C., Hemam, N.S., Neill, D. B., (2004), 'Do women really need marital partners for support of their reproductive success? the case of the matrilineal khasi of n. e. india, in Michael Alvard (ed.) Socioeconomic Aspects of Human Behavioral Ecology (Research in Economic Anthropology, Volume 23), Emerald Group Publishing Limited, pp.151-174. 
Levati, M. V., Sutter, M., \& Van der Heijden, E. (2007). Leading by example in a public goods experiment with heterogeneity and incomplete information.Journal of Conflict Resolution, 51(5), 793-818.

Lin, E. S. (2010). Gender wage gaps by college major in Taiwan: Empirical evidence from the 1997-2003 Manpower Utilization Survey. Economics of Education Review 29, 156164.

Machin, S. and P. A. Puhani (2003). Subject of degree and the gender wage gap differential: Evidence from the UK and Germany. Economic Letters 79, 393-400.

Malhotra, A., \& Mather, M. (1997, December). Do schooling and work empower women in developing countries? Gender and domestic decisions in Sri Lanka. InSociological Forum (Vol. 12, No. 4, pp. 599-630). Kluwer Academic Publishers-Plenum Publishers.

Malhotra, A., \& Schuler, S. R. (2005). Women's empowerment as a variable in international development. Measuring empowerment: Cross-disciplinary perspectives, 71-88.

Manser, M., \& Brown, M. (1980). Marriage and household decision making: A bargaining Analysis. International Economic Review, 21(1), 31-44.

Mason, K. O. (1986, March). The status of women: Conceptual and methodological issues in demographic studies. In Sociological Forum (Vol. 1, No. 2, pp. 284-300). Kluwer Academic Publishers.

McElroy, M. B. (1990). The empirical content of Nash bargained household behavior. Journal of Human Resources, 25(4), 559-583.

McElroy, M., \& Horney M. (1981). Nash-bargained decisions: Towards a generalization of the theory of demand. International Economic Review, 22, 333-349.

Meidinger, C., Rullière, J. L., \& Villeval, M. C. (2003). Does team-based compensation give rise to problems when agents vary in their ability?.Experimental Economics, 6(3), 253-272.

Mobius, M. M., M. Niederle, P. Niehaus, and T. S. Rosenblat. (2011). Managing selfconfidence: Theory and experimental evidence. National Bureau of Economic Research.

Moser, C. (2012). Gender planning and development: Theory, practice and training. Routledge.

Moxnes, E., \& Van der Heijden, E. (2003). The effect of leadership in a public bad experiment. Journal of Conflict Resolution, 47(6), 773-795.

Narrod, C., Roy, D., Okello, J., Avendaño, B., \& Rich, K. (2007). The role of public-private partnerships and collective action in ensuring smallholder participation in high value fruit and vegetable supply chains (No. 70). International Food Policy Research Institute (IFPRI).

Ngimwa, P., Ocholla, D. N., \& Ojiambo, J. (1997). Media accessibility and utilization by Kenyan rural women. The International Information \& Library Review, 29(1), 45-66.

Niederle, M., \& Vesterlund, L. (2007). Do women shy away from competition? Do men compete too much? The Quarterly Journal of Economics, 122, 1067-1101.

Oxaal, Z., \& Baden, S. (1997). Gender and empowerment: definitions, approaches and implications for policy (No. 40). Bridge, Institute of Development Studies. 
Pande, R. P. (2003). Selective gender differences in childhood nutrition and immunization in rural India: the role of siblings. Demography, 40(3), 395-418.

Planning Commission of India. (2007a). Spatial development and regional imbalances. The Eleventh Five Year Plan of India, pp. 137-151.

Planning Commission of India. (2007b). Environment and climate change, The Eleventh Five Year Plan of India, pp. 191-207.

Potters, J., Sefton, M., \& Vesterlund, L. (2005). After you-endogenous sequencing in voluntary contribution games. Journal of Public Economics,89(8), 1399-1419.

Potters, J., Sefton, M., \& Vesterlund, L. (2007). Leading-by-example and signaling in voluntary contribution games: an experimental study. Economic Theory, 33(1), 169182.

Powell, M., \& Ansic, D. (1997). Gender differences in risk behaviour in financial decisionmaking: An experimental analysis. Journal of economic psychology,18(6), 605-628.

Quisumbing, A. R., \& Pandolfelli, L. (2010). Promising approaches to address the needs of poor female farmers: Resources, constraints, and interventions. World Development, 38(4), 581-592.

Rao, N. (2005). Questioning Women's Solidarity: The Case of Land Rights, Santal Parganas, Jharkhand, India. The Journal of Development Studies, 41(3), 353-375.

Ravindranath, N. H., Rao, S., Sharma, N., Nair, M., Gopalakrishnan, R., Rao, A. S., ... \& Bala, G. (2011). Climate change vulnerability profiles for North East India. Current Science (Bangalore), 101(3), 384-394.

Rivas, M. F., \& Sutter, M. (2011). The benefits of voluntary leadership in experimental public goods games. Economics Letters, 112(2), 176-178.

Roberts, T. A., \& Nolen-Hoeksema, S. (1989). Sex differences in reactions to evaluative feedback. Sex Roles, 21(11-12), 725-747.

Rocheleau, Dianne and David Edmunds. 1997. “Women, Men, and Trees: Gender, Power, and Property in Forest and Agrarian Landscapes." World Development 25(8): 1351 71.

Rose, S., \& Hartmann, H. I. (2004). Still a man's labor market: The long-term earnings gap. Institute for Women's Policy Research.

Rowlands, J. (1995). Empowerment examined. Development in practice, 5(2), 101-107.

Roy, A., Murry, B. (2013). Gender disparity in Socio Demographic variables among the Tribals of Eastern India: a case study of the Santals. International Journal of Human Sciences. 10(1), 343-355.

Sadik, N. (1993). Education of girls. Integration (Tokyo, Japan), (36), 20.

Schubert, R., M. Brown, M. Gysler \& H. W. Brachinger (1999) 'Financial Decision-Making: Are Women Really More Risk-Averse?,' American Economic Review (Papers and Proceedings) 89 (2), 381-385.

Sen, A. (1990). Gender and Cooperative Conflicts, in Tinker, I.(ed.), Persistent Inequalities: Women and World Development, Oxford University Press.

Sen, A. (1999). Development as freedom. New York. Sen, G. and Batliwala, S.(2000)'Empowering women for reproductive rights', in. 
Shupp, R. S., \& Williams, A. W. (2008). Risk preference differentials of small groups and individuals. The Economic Journal, 118(525), 258-283.

Sinja, J., L. Njoroge, H. Mbaya, H. Magara, E. Mwangi, I. Baltenweck, D. Romney, and A. Omore. (2006). Milk Market Access for Smallholders: A Case of Informal Milk Trader Groups in Kenya. CGIAR systemwide program on collective action and property rights (CAPRi).

Stockbridge, M., Dorward, A., Kydd, J. (2003). Farmer Organizations for Market Access: Learning from Success. Briefing Paper. Wye College, University of London, UK.

Sutter, M. (2009). Individual behavior and group membership: Comment. The American Economic Review, 2247-2257.

Sutter, M., Kocher, M. G., Glatzle-Rutzler, D., \& Trautmann, S. T. (2013). Impatience and uncertainty: Experimental decisions predict adolescents' field behavior. The American Economic Review, 103(1), 510-531.

Svaleryd, H. (2002). Female representation: Is it important for policy decisions?. Department of Economics, Stockholm University.

Tefft, J. (2004). Mali's white revolution: smallholder cotton from 1960 to 2003. 2020 Vision Focus Brief, vol. 12. International Food Policy Research Institute, Washington, DC.

Thomas, D. (1997). Incomes, expenditures, and health outcomes: Evidence on intrahousehold resource allocation. In L. Haddad, J. Hoddinott, \& H. Alderman, Intrahousehold resource allocation in developing countries (pp. 142-164). Baltimore: Johns Hopkins University Press.

Thomas, S., \& Welch, S. (1991). The impact of gender on activities and priorities of state legislators. The Western Political Quarterly, 445-456.

Thorp, R., Stewart, F., \& Heyer, A. (2005). When and how far is group formation a route out of chronic poverty?. World Development, 33(6), 907-920.

Thorsen, D. (2002). 'We Help our Husbands!'Negotiating the Household Budget in Rural Burkina Faso. Development and Change, 33(1), 129-146.

Torres-Spelliscy, C., Chase, M., \& Greenman, E. (2008). Improving judicial diversity. Brennan Center for Justice, New York University School of Law.

Tversky, A., D. Kahneman (1992). Advances in Prospect Theory: Cumulative Representations of Uncertainty. Journal of Risk and Uncertainty, Vol. 5 (4), pp. 297323.

Udry, C. (1996). Gender, agricultural production, and the theory of the household. Journal of political Economy, 1010-1046.

Udry, C., Hoddinott, J., Alderman, H., \& Haddad, L. (1995). Gender differentials in farm productivity: Implications for household efficiency and agricultural policy. Food Policy, 20(5), 407-423.

Van der Heijden, K., Bradfield, R., Burt, G., Cairns, G., \& Wright, G. (2009).The sixth sense: Accelerating organizational learning with scenarios. John Wiley \& Sons.

VAN HAM, P. (2000): The Seven Sisters of India: Tribal Worlds Between Tibet and Burma. Munich, London, and New York: Prestel Publishers.

Wakker, P. P. (2010). Prospect theory: For risk and ambiguity (Vol. 44). Cambridge: Cambridge University Press. 
World Bank (2011). Gender equality and development. World development report 2012. Washington, DC: World Bank.

World Bank, FAO, and IFAD. (2009). Gender in agriculture sourcebook. Agriculture and rural development series. Washington, DC: World Bank.

World Bank, FAO, and IFAD.(2009). Gender in agriculture sourcebook. Agriculture and rural development series. Washington, DC: World Bank.

World Bank. (2001). Engendering development; through gender equality in rights, resources and voice. World Bank policy research report. Washington, DC: World Bank.

Yesuf, M., \& Bluffstone, R. A. (2009). Poverty, risk aversion, and path dependence in lowincome countries: Experimental evidence from Ethiopia. American Journal of Agricultural Economics, 91(4), 1022-1037.

Zwarteveen, M. (1996). A plot of one's own: Gender relations and irrigated land allocation policies in Burkina Faso. Research report no. 10. Colombo, Sri Lanka: International Irrigation Management Institute. 


\section{APPENDIX}

Table A.1: Testing for the exogeneity of \% of male farmers selling collectively in village

\begin{tabular}{|c|c|c|}
\hline Dependent variable: Share of revenue controlled by farmer & Model1 & Model2 \\
\hline Participation & $\begin{array}{c}0.017 \\
(0.021)\end{array}$ & $\begin{array}{c}0.023 \\
(0.022)\end{array}$ \\
\hline$\%$ of male farmers selling collectively in village & $\begin{array}{l}-0.129 \\
(0.236)\end{array}$ & $\begin{array}{l}-0.166 \\
(0.231)\end{array}$ \\
\hline$\%$ of male farmers selling collectively in village*Female & & $\begin{array}{c}0.013 \\
(0.040)\end{array}$ \\
\hline Female & $\begin{array}{l}-0.005 \\
(0.024)\end{array}$ & $\begin{array}{l}-0.047 \\
(0.035)\end{array}$ \\
\hline Age & $\begin{array}{c}0.001 \\
(0.004)\end{array}$ & $\begin{array}{c}0.002 \\
(0.004)\end{array}$ \\
\hline Age sq. & $\begin{array}{l}-0.002 \\
(0.003)\end{array}$ & $\begin{array}{l}-0.003 \\
(0.003)\end{array}$ \\
\hline Household size & $\begin{array}{c}0.000 \\
(0.002)\end{array}$ & $\begin{array}{c}0.000 \\
(0.002)\end{array}$ \\
\hline Married & $\begin{array}{l}-0.021 \\
(0.021)\end{array}$ & $\begin{array}{l}-0.045^{*} \\
(0.027)\end{array}$ \\
\hline Primary completed & $\begin{array}{l}0.022^{*} \\
(0.013)\end{array}$ & $\begin{array}{l}0.024 * \\
(0.013)\end{array}$ \\
\hline Secondary and above & $\begin{array}{l}-0.010 \\
(0.031)\end{array}$ & $\begin{array}{l}-0.007 \\
(0.031)\end{array}$ \\
\hline Land title & $\begin{array}{c}0.028 \\
(0.021)\end{array}$ & $\begin{array}{c}0.022 \\
(0.025)\end{array}$ \\
\hline Cocoa area & $\begin{array}{l}-0.023 \\
(1.229)\end{array}$ & $\begin{array}{c}0.097 \\
(1.251)\end{array}$ \\
\hline Non-farm activity & $\begin{array}{l}-0.011 \\
(0.016)\end{array}$ & $\begin{array}{l}-0.013 \\
(0.016)\end{array}$ \\
\hline Extension service & $\begin{array}{l}-0.005 \\
(0.014)\end{array}$ & $\begin{array}{l}-0.007 \\
(0.014)\end{array}$ \\
\hline Age of cocoa plant(months) & & $\begin{array}{c}-5.0 \mathrm{E}-05 \\
(4.0 \mathrm{E}-05)\end{array}$ \\
\hline Land title*Female & & $\begin{array}{c}0.020 \\
(0.039)\end{array}$ \\
\hline Married*Female & & $\begin{array}{l}0.069^{*} \\
(0.041)\end{array}$ \\
\hline Constant & $\begin{array}{c}0.456^{* * * *} \\
(0.133)\end{array}$ & $\begin{array}{c}0.459 * * * \\
(0.132)\end{array}$ \\
\hline Observations & 911 & 911 \\
\hline
\end{tabular}

Note: Robust standard errors in parentheses; $* * * \mathrm{p}<0.01, * * \mathrm{p}<0.05, * \mathrm{p}<0.1$; for education the left-out category is less than primary education; village fixed effects are included in all models 
Table A.2: First stage regression results of IV models presented in Table 2.6

\begin{tabular}{|c|c|c|c|c|c|c|c|}
\hline & $\begin{array}{c}\text { (M1) } \\
\text { Participate }\end{array}$ & $\begin{array}{c}\text { (M2) } \\
\text { Participate }\end{array}$ & $\begin{array}{c}\text { (M3) } \\
\text { Participate }\end{array}$ & $\begin{array}{c}\text { (M4) } \\
\text { Participate }\end{array}$ & $\begin{array}{c}\text { (M4) } \\
\text { Participate } \\
\text { *Female }\end{array}$ & $\begin{array}{c}\text { (M5) } \\
\text { Participate }\end{array}$ & \begin{tabular}{l}
\multicolumn{1}{c}{$(\mathrm{M} 5)$} \\
Participation \\
*Female
\end{tabular} \\
\hline Female & $\begin{array}{c}-0.329^{* * *} \\
(0.068)\end{array}$ & $\begin{array}{c}-0.223^{* * * *} \\
(0.083)\end{array}$ & $\begin{array}{c}-0.329^{* * * *} \\
(0.068)\end{array}$ & $\begin{array}{c}-0.206^{* * * *} \\
(0.072)\end{array}$ & $\begin{array}{l}0.733^{* * * *} \\
(0.070)\end{array}$ & $\begin{array}{c}-0.232^{* * *} \\
(0.083)\end{array}$ & $\begin{array}{l}0.702^{* * *} \\
(0.079)\end{array}$ \\
\hline Age & $\begin{array}{l}0.011^{*} \\
(0.006)\end{array}$ & $\begin{array}{c}0.008 \\
(0.005)\end{array}$ & $\begin{array}{l}0.011^{*} \\
(0.006)\end{array}$ & $\begin{array}{l}-0.001 \\
(0.001)\end{array}$ & $\begin{array}{l}-0.000 \\
(0.001)\end{array}$ & $\begin{array}{l}-0.001 \\
(0.001)\end{array}$ & $\begin{array}{l}-0.000 \\
(0.001)\end{array}$ \\
\hline Age sq & $\begin{array}{l}-1.0 \mathrm{e}-04^{*} \\
(5.0 \mathrm{e}-05)\end{array}$ & $\begin{array}{l}-9.0 \mathrm{e}-05^{*} \\
(5.0 \mathrm{e}-05)\end{array}$ & $\begin{array}{l}-1.0 \mathrm{e}-04^{*} \\
(5.0 \mathrm{e}-05)\end{array}$ & & & & \\
\hline Household size & $\begin{array}{c}0.004 \\
(0.002)\end{array}$ & $\begin{array}{c}0.004 \\
(0.002)\end{array}$ & $\begin{array}{c}0.004 \\
(0.002)\end{array}$ & $\begin{array}{l}0.004^{*} \\
(0.002)\end{array}$ & $\begin{array}{c}0.003 \\
(0.002)\end{array}$ & $\begin{array}{l}0.005^{* *} \\
(0.002)\end{array}$ & $\begin{array}{l}0.004^{*} \\
(0.002)\end{array}$ \\
\hline Married & $\begin{array}{l}-0.061 \\
(0.049)\end{array}$ & $\begin{array}{c}0.008 \\
(0.039)\end{array}$ & $\begin{array}{l}-0.060 \\
(0.049)\end{array}$ & & & $\begin{array}{l}-0.055 \\
(0.050)\end{array}$ & $\begin{array}{l}-0.067 \\
(0.043)\end{array}$ \\
\hline Primary & $\begin{array}{c}0.040 \\
(0.025)\end{array}$ & $\begin{array}{c}0.035 \\
(0.024)\end{array}$ & $\begin{array}{c}0.040 \\
(0.025)\end{array}$ & $\begin{array}{c}0.036 \\
(0.025)\end{array}$ & $\begin{array}{c}0.023 \\
(0.019)\end{array}$ & $\begin{array}{c}0.040 \\
(0.027)\end{array}$ & $\begin{array}{c}0.026 \\
(0.021)\end{array}$ \\
\hline Secondary & $\begin{array}{l}0.088^{* * *} \\
(0.038)\end{array}$ & $\begin{array}{l}0.080^{* *} \\
(0.036)\end{array}$ & $\begin{array}{l}0.088^{* *} \\
(0.038)\end{array}$ & $\begin{array}{l}0.095^{* *} \\
(0.037)\end{array}$ & $\begin{array}{c}0.043 \\
(0.028)\end{array}$ & $\begin{array}{l}0.088^{* *} \\
(0.039)\end{array}$ & $\begin{array}{c}0.029 \\
(0.026)\end{array}$ \\
\hline Land title & $\begin{array}{l}-0.041 \\
(0.036)\end{array}$ & $\begin{array}{l}-0.036 \\
(0.035)\end{array}$ & $\begin{array}{l}-0.041 \\
(0.036)\end{array}$ & $\begin{array}{l}-0.045 \\
(0.038)\end{array}$ & $\begin{array}{l}-0.021 \\
(0.031)\end{array}$ & $\begin{array}{l}-0.039 \\
(0.038)\end{array}$ & $\begin{array}{l}-0.016 \\
(0.031)\end{array}$ \\
\hline Area of & $\begin{array}{c}0.001 \\
(0.003)\end{array}$ & $\begin{array}{c}0.001 \\
(0.003)\end{array}$ & $\begin{array}{c}0.001 \\
(0.003)\end{array}$ & $\begin{array}{c}0.001 \\
(0.003)\end{array}$ & $\begin{array}{c}0.001 \\
(0.002)\end{array}$ & $\begin{array}{l}0.0003 \\
(0.003)\end{array}$ & $\begin{array}{c}0.001 \\
(0.002)\end{array}$ \\
\hline Non-farm & $\begin{array}{l}-0.011 \\
(0.027)\end{array}$ & $\begin{array}{l}-0.008 \\
(0.026)\end{array}$ & $\begin{array}{l}-0.011 \\
(0.027)\end{array}$ & & & $\begin{array}{l}-0.002 \\
(0.028)\end{array}$ & $\begin{array}{c}0.011 \\
(0.019)\end{array}$ \\
\hline Extension & $\begin{array}{c}0.004 \\
(0.019)\end{array}$ & $\begin{array}{c}0.008 \\
(0.020)\end{array}$ & & $\begin{array}{c}0.009 \\
(0.017)\end{array}$ & $\begin{array}{l}-0.008 \\
(0.010)\end{array}$ & $\begin{array}{c}0.013 \\
(0.017)\end{array}$ & $\begin{array}{l}-0.003 \\
(0.009)\end{array}$ \\
\hline Age of plant & & & & $\begin{array}{l}-2.3 \mathrm{E}-05 \\
(5.0 \mathrm{E}-05)\end{array}$ & $\begin{array}{l}-2.3 \mathrm{E}-05 \\
(3.0 \mathrm{E}-05)\end{array}$ & $\begin{array}{c}-2.3 \mathrm{E}-05 \\
(5.0 \mathrm{E}-05)\end{array}$ & $\begin{array}{l}-2.3 \mathrm{E}-05 \\
(3.0 \mathrm{E}-05)\end{array}$ \\
\hline Land* Female & & $\begin{array}{l}-0.019 \\
(0.101)\end{array}$ & & & & & \\
\hline $\begin{array}{l}\text { Married* } \\
\text { Female }\end{array}$ & & $-0.198^{*}$ & & & & & \\
\hline IV & $\begin{array}{l}1.610^{* * * *} \\
(0.404)\end{array}$ & $\begin{array}{l}(0.110) \\
1.714^{* * *} \\
(0.413)\end{array}$ & $\begin{array}{l}1.587^{* * * *} \\
(0.370)\end{array}$ & $\begin{array}{l}0.268^{* * *} \\
(0.094)\end{array}$ & $\begin{array}{c}0.267^{* * *} \\
(0.085)\end{array}$ & $\begin{array}{l}0.302^{* * *} \\
(0.091)\end{array}$ & $\begin{array}{l}0.306^{* * * *} \\
(0.081)\end{array}$ \\
\hline IV *Female & & & & $\begin{array}{l}-0.276^{*} \\
(0.166)\end{array}$ & $\begin{array}{l}-0.233 \\
(0.161)\end{array}$ & $\begin{array}{l}-0.302^{*} \\
(0.168)\end{array}$ & $\begin{array}{l}-0.264 \\
(0.162)\end{array}$ \\
\hline $\begin{array}{l}\text { Endogeneity test } \\
\text { (p-val) }\end{array}$ & 0.16 & 0.04 & 0.04 & 0.04 & 0.00 & 0.00 & 0.00 \\
\hline F-stat & 15.92 & 17.22 & 18.43 & 5.09 & 8.34 & 6.68 & 11.5 \\
\hline Observations & 911 & 911 & 911 & 911 & 911 & 911 & 911 \\
\hline
\end{tabular}




\section{A Randomization Tests}

Table A.3: Comparisons of Covariates by Treatments

\begin{tabular}{|c|c|c|c|c|c|c|}
\hline \multicolumn{7}{|c|}{ Panel A: Matrilineal Society } \\
\hline & GP vs. GRP & GP vs. AGR & GP vs. GRPAA & GRP vs. AGR & GRP vs. GRPAA & AGR vs. GRPAA \\
\hline \multirow[t]{2}{*}{ Age } & -0.718 & 2.883 & 1.344 & 3.602 & 2.062 & -1.539 \\
\hline & $(3.245)$ & $(2.564)$ & $(2.430)$ & $(3.212)$ & (3.109) & (2.399) \\
\hline \multirow[t]{2}{*}{ Household size } & -0.500 & -0.700 & -0.271 & -0.200 & 0.229 & 0.429 \\
\hline & $(0.774)$ & $(0.560)$ & $(0.669)$ & $(0.720)$ & $(0.808)$ & $(0.609)$ \\
\hline \multirow[t]{2}{*}{ Children under 5 years } & $-0.738^{* *}$ & $-1.251^{* * * *}$ & -0.507 & -0.513 & 0.231 & 0.744 \\
\hline & $(0.288)$ & $(0.390)$ & $(0.344)$ & $(0.427)$ & $(0.385)$ & $(0.467)$ \\
\hline \multirow[t]{2}{*}{ Household head male } & 0.128 & 0.061 & -0.070 & -0.067 & $-0.198^{*}$ & -0.131 \\
\hline & $(0.125)$ & $(0.113)$ & $(0.107)$ & $(0.121)$ & $(0.117)$ & $(0.103)$ \\
\hline \multirow[t]{2}{*}{ Primary education } & 0.052 & 0.094 & 0.024 & 0.043 & -0.027 & -0.070 \\
\hline & $(0.095)$ & $(0.077)$ & $(0.087)$ & $(0.078)$ & $(0.087)$ & $(0.068)$ \\
\hline \multirow[t]{2}{*}{ Secondary education } & $0.210^{*}$ & 0.072 & -0.063 & -0.138 & $-0.274 * *$ & -0.135 \\
\hline & $(0.125)$ & $(0.104)$ & $(0.105)$ & $(0.115)$ & $(0.116)$ & $(0.093)$ \\
\hline $\mathrm{N}$ & 100 & 100 & 104 & 120 & 124 & 124 \\
\hline \multicolumn{7}{|c|}{ Panel B: Patriarchal Society } \\
\hline & GP vs. GRP & GP vs. AGR & GP vs. GRPAA & GRP vs. AGR & GRP vs. GRPAA & AGR vs. GRPAA \\
\hline \multirow[t]{2}{*}{ Age } & -1.676 & $-5.731 * * *$ & -1.868 & $-4.055^{* *}$ & -0.192 & $3.863^{*}$ \\
\hline & $(1.754)$ & (1.793) & (1.949) & $(1.785)$ & $(1.942)$ & $(1.977)$ \\
\hline \multirow[t]{2}{*}{ Household size } & $1.924 * * *$ & $1.050^{* *}$ & -0.138 & $-0.874 * *$ & $-2.062 * * *$ & $-1.188^{* *}$ \\
\hline & $(0.390)$ & $(0.443)$ & $(0.520)$ & $(0.360)$ & $(0.452)$ & $(0.498)$ \\
\hline \multirow[t]{2}{*}{ Children under 5 years } & $0.360^{* * * *}$ & -0.009 & -0.013 & $-0.369^{* *}$ & $-0.372 * * *$ & -0.004 \\
\hline & $(0.134)$ & $(0.156)$ & $(0.145)$ & $(0.152)$ & $(0.140)$ & $(0.162)$ \\
\hline \multirow[t]{2}{*}{ Household head male } & 0.007 & $-0.087 * *$ & 0.013 & $-0.095 *$ & 0.005 & $0.100^{* *}$ \\
\hline & $(0.059)$ & $(0.043)$ & $(0.054)$ & $(0.051)$ & $(0.060)$ & $(0.044)$ \\
\hline \multirow[t]{2}{*}{ Primary education } & $-0.192 * * *$ & $-0.138 * *$ & 0.025 & 0.054 & $0.217 * * *$ & $0.162 * * *$ \\
\hline & $(0.063)$ & $(0.057)$ & $(0.042)$ & $(0.072)$ & $(0.061)$ & $(0.054)$ \\
\hline \multirow[t]{2}{*}{ Secondary education } & 0.001 & 0.100 & -0.075 & 0.099 & -0.076 & $-0.175^{* *}$ \\
\hline & $(0.082)$ & $(0.076)$ & $(0.079)$ & $(0.080)$ & $(0.082)$ & $(0.077)$ \\
\hline $\mathrm{N}$ & 176 & 160 & 160 & 176 & 176 & 160 \\
\hline
\end{tabular}

Note: Pairwise differences of treatment arms using t-test with heteroskedastcity robust standard errors are reported at the following levels $* * * \mathrm{p}<0.01, * * \mathrm{p}<0.05, * \mathrm{p}<0.1$

\section{B Experimental Protocol and Instructions}

Notes concerning the protocol: The protocol was translated into the local language and then retranslated to English in order to ensure that the information conveyed was correctly translated into the local language. 
The instructions were explained with the help of flipcharts that summarized the most important points and subjects were required to answer control questions to make sure that they understood the payment structure of the game.

\section{B Instructions for the participants}

Welcome to today's experiment on economic decision making. We will pay you Rs. 20 for participating in our experiment and in addition to that you can earn more money depending on your decisions and the decisions of others.

It is strictly forbidden to communicate with the other participants during the experiment. If you have any questions or concerns, please raise your hand. We will answer your questions individually. It is very important that you follow this rule. Otherwise we must exclude you from the experiment and from all payments.

What do you need to do during the experiment?

There will be two rounds in this game. In each round you will be a member of a group of four. Groups will be assembled randomly. Three participants in the group will play role A and one participant will be in role B. in the end you will be paid only for randomly selected round.

What shall the participants in role A do?

At the beginning of the experiment you receive Rs. 30 that we will call "endowment". This is in addition to the amount (Rs. 20) that you receive as participation fees. Each of the three participants in role A has to decide how to divide this endowment. You can put all, some or nothing of your endowment into a joint account of the group. Rest of the amount that you do not put in groups' joint account goes into your private pocket.

Your income from the group joint account:

To determine your income from the joint account total contribution by the three participants in role A will be invested in an agricultural project. As a return total investment will be doubled and divided equally between the three. For example, if three of you in a group invest everything in the joint account, the sum of all contributions to the group account is $30+30+30=$ Rs 90 , you and all other contributors will get an income of $90 \times 2 / 3=60$ from the joint account. If the three group members deposit a total of 12 in the group account, then you and all others will receive an income of $12 \times 2 / 3=8$ tokens from the group account. (Use posters here) Thus each participant in role A receives same income from the joint account. It does not depend on who contributes what amount. Total income of each contributor=amount in the private pocket + income from the joint account. Is it clear to everyone?

Control question 1. If two contributors in a group invest $r s .27$ in total in the joint account and the other one invests nothing

a. What is the total investment in the joint account (ans 27)

b. What would be the total income from the joint account? (ans. $27 * 2=54$ )

c. How much each participant in role A earns from the joint account.(ans. 54/3=18) 
d. How much you have kept in your private pocket if you have invested nothing in the joint account?(ans.30)

e. What would be your total income?(ans. $30+18=48$ )

f. How much you have kept in your private pocket if you have invested 12 in the joint account?(ans.18)

g. What would be your total income?(ans. $18+18=36)$

h. How much you have kept in your private pocket if you have invested 15 in the joint account?(ans.15)

i. What would be your total income?(ans. $15+18=33$ )

(Please spend sufficient tie here and do not provide your personal opinion. Also control subjects such a way that they also do not provide any opinion in public. Only important thing is they understand the rule of earning income)

What shall the participant in role B do?

One participant in the group will be in role B. He would receive a fixed payment of receives Rs.50. This is in addition to the participation fee that is given to everyone (Rs.20). The task is to observe the investment decisions of the three participants in role A and then provide feedback on the decisions. After observing the three contributions B has the option to punish those in role A. Punishment could be given in the form deduction in total income that contributors earn from the game. You can assign punishment points to the contributors. You are free to decide how many points she (he) wants to assign to each in role A.

\section{(Use punishment point poster here)}

However, you must choose a number between 0, 1, 2, 3, 4 and 5 as punishment point. Sending punishment point is not costless. You must choose the punishment point carefully as each punishment point has an equivalent cost, therefore, corresponding income reduction to send the above mentioned punishment points would be Rs. 0, Rs. 1, Rs.2, Rs.3, Rs.4, and Rs. 5. For the participants in role A who will receive the punishment points from the B corresponding income reduction would be the double of the received point, which are, Rs. 0 , Rs. 2, Rs.4, Rs.6, Rs.8, Rs.10 respectively. These costs will be subtracted from the round payoff. At the end of the period B and A would know their total earnings for the period.

(TREATMENT: Giving \& Receiving) After B decides how many points she (he) wants to send, participant in role A can provide feedback on B's task. Similar as B they have to decide whether they want to send points to B. Sending points to B would cost A an equivalent amount and the leader as before. Sender's income will be reduced by the same amount that he (she) would but B's income will be reduced by the double of the point he would receive. Participants are free to decide how many points they want to send to leader from $0,1,2,3,4$, 5.

Is everyone with me so far?

Selection of Leader and Contributors [THIS IS TREAMENT SPECIFIC]

[BASELINE 1: Exogenous B]: We will randomly select one participant from each group for the role $\mathrm{B}$.

[TREATMENT Self-selected B] We will now distribute the decision sheets where we ask you to indicate whether you would like to be A or a B. If you like to be in role B please put a tick mark on $\mathrm{B}$, otherwise on $\mathrm{A}$. If there is more than one person in a group who would be 
interested in playing the role $\mathrm{B}$, one would be randomly selected into this role, while the others will be assigned in the role B. If no one is interested in role B we will select one participant from the group randomly for the role.

[TREATMENT Preferential treatment for female in role B]: Please indicate whether you would like to take role A or role B. If there is a female participant in the group who is willing to take up role $\mathrm{B}$, she will be selected for the role. If there is more than one female candidate, who volunteers for the role, we will select one randomly. If no female candidates volunteers we select one of the willing male candidates randomly; while the others will be assigned in role A. If no one is interested in role B we will select one participant from the group randomly.

(TREATMENT: Public): Once the candidates in role B are selected they will be introduced to you all.

(Distribute Role Sheet1)

\section{[IMPLEMENTATION] [Be Slow Here]}

While it is decided who is selected as in role B, we would like to ask all of you to decide how much you would like to contribute to the group joint account in case you are in role A. In other words I am asking all of you to make your contribution decisions. Decisions of those who will be selected I in role A will be taken into account. You will have 1 minute to take your decisions after I ask you to start.

\section{(Distribute Contribution Sheet2)}

Your decisions are being registered; soon you will receive information on the decisions of others in your group. While the information is being processed, we want to ask you to guess how much the other three members would contribute on average to the group account. If your guessed amount falls within a range of $+/-$ Rs 5 of the actual contributions, for each such guess you will receive Rs 5 as reward. Outside this range, however, there will be no reward. You will have one minute to guess.

\section{(Distribute the expectation sheet 3 )}

The paper that you will receive next explains if you have been selected in role A or B. Those who will be selected as B will have the information on the contributions from the three A. (Show the point poster again)

For A, the task is to guess how many points B would send. If you guess it correctly you will receive Rs 5 as reward. For B the task is to provide the punishment pints for all A.

\section{(Distribute Feedback Sheet 4\&5)}

You may now see your role.

[TREATMENT: Public]Participants in role $\mathrm{B}$ are now asked to raise their hands so that everyone can see them.

While your decisions are being registered, let me explain the information that you will receive next. Soon you will receive a paper like this one (show example), the paper summarizes the results of the game so far. In the table it explains how much three A contributed individually to the group account, and summarizes the punishment points from B to three A. For A, the task is to observe the contributions in the game and corresponding points given by $\mathrm{B}$. Then each $\mathrm{A}$ has to decide how many punishment points he/she wants to send to B. Cost of 
punishment given and received remains the same. You can send as many points to B as you wish, but you should not exceed the range. Please register your decision in your decision sheet. The task of B is to guess how many points he (she) will receive from the three as in the group. If you guess it correctly you will receive Rs 5 as reward for each correct guess. $6 \&$

\section{(Distribute decision Sheet 7)}

Thank you for participating in this round. You will receive information on total earning in the game at the end of the experiment. Second Round Now we would like to repeat the game. However, the conditions of the game will change slightly. So please listen carefully.

First we will form new groups with four participants. Similarly as before, within each group, three participants will play role A and one participant will play role B.

A s will do exactly the same as in the previous round. Each A will receive Rs. 30 as "endowment" and have to decide how to divide this endowment. You can put all, some or none of your endowment into a joint account. The amount you do not deposit in the joint account will automatically be transferred to your private pocket. The amount that you put in the joint account gives a payment to you and to other persons in the group. Everybody receives the same income from group account, independent of the amount invested. Similarly, you will also earn an income from the tokens that the other group members put into the group account. After making the contribution, participants in role B will observe and provide feedback by sending points to each A. Cost of sending and receiving punishment points is similar as it was in the first round. After B decides how many points he wants to send, A can decide whether they want to send points to B. Thus the game remains the same and you play the same game again in new group. We will now distribute the decision sheet. Please indicate whether you would like to be in role A or B in four following alternative scenarios. In the first scenario, participants in role B receive Rs. 30: In the second scenario, participants in role B receive Rs. 50 In the third scenario, participants in role B receive Rs. 70 In the third scenario, and participants in role B receive Rs. 90

If there is more than one person interested in role $\mathrm{B}$, one would be randomly selected for this role and we will implement the scenario which he/she would opt for role B. Others will be assigned in role A. If no one is interested in role B we will select one participant from the group and one scenario randomly. All other procedures are the same as in the previous round. Please indicate your preferred role for the three scenarios.

(Distribute scenario sheet 8)

Continue with [IMPLEMENTATION] 
4A Regression with and without socio-economic controls for essay 3

Table A.4: OLS estimation of risk and ambiguity attitude with socioeconomic controls

\begin{tabular}{|c|c|c|c|c|c|c|c|c|}
\hline & IR & GR & IA & GA & IR & GR & IA & GA \\
\hline Male & $\begin{array}{l}-0.21 * * * \\
(0.04)\end{array}$ & $\begin{array}{l}-0.21 * * * \\
(0.04)\end{array}$ & $\begin{array}{l}-0.02 \\
(0.04)\end{array}$ & $\begin{array}{l}0.02 \\
(0.04)\end{array}$ & $\begin{array}{l}-0.18 * * * \\
(0.04)\end{array}$ & $\begin{array}{l}-0.16^{* * * *} \\
(0.04)\end{array}$ & $\begin{array}{l}-0.04 \\
(0.04)\end{array}$ & $\begin{array}{l}0.01 \\
(0.04)\end{array}$ \\
\hline Matrilineal & $\begin{array}{l}0.09 * \\
(0.05)\end{array}$ & $\begin{array}{l}0.08 * \\
(0.05)\end{array}$ & $\begin{array}{l}-0.04 \\
(0.06)\end{array}$ & $\begin{array}{l}-0.00 \\
(0.05)\end{array}$ & $\begin{array}{l}0.15^{* *} \\
(0.06)\end{array}$ & $\begin{array}{l}0.14 * * \\
(0.06)\end{array}$ & $\begin{array}{l}-0.08 \\
(0.07)\end{array}$ & $\begin{array}{l}-0.08 \\
(0.06)\end{array}$ \\
\hline Matrilineal*Male & $\begin{array}{l}0.11 \\
(0.07)\end{array}$ & $\begin{array}{l}0.11 * \\
(0.06)\end{array}$ & $\begin{array}{l}0.03 \\
(0.07)\end{array}$ & $\begin{array}{l}-0.03 \\
(0.07)\end{array}$ & $\begin{array}{l}0.08 \\
(0.07)\end{array}$ & $\begin{array}{l}0.08 \\
(0.07)\end{array}$ & $\begin{array}{l}0.01 \\
(0.08)\end{array}$ & $\begin{array}{l}0.01 \\
(0.08)\end{array}$ \\
\hline Male majority & $\begin{array}{l}0.05 \\
(0.06)\end{array}$ & $\begin{array}{l}0.23 * * * \\
(0.06)\end{array}$ & $\begin{array}{l}0.18 * * * \\
(0.06)\end{array}$ & $\begin{array}{l}0.04 \\
(0.06)\end{array}$ & $\begin{array}{l}0.08 \\
(0.06)\end{array}$ & $\begin{array}{l}0.24 * * * \\
(0.06)\end{array}$ & $\begin{array}{l}0.13 * \\
(0.07)\end{array}$ & $\begin{array}{l}-0.00 \\
(0.07)\end{array}$ \\
\hline Bag A first & $\begin{array}{l}0.11 * \\
(0.06)\end{array}$ & $\begin{array}{l}0.16^{* * * *} \\
(0.06)\end{array}$ & $\begin{array}{l}0.03 \\
(0.07)\end{array}$ & $\begin{array}{l}0.03 \\
(0.06)\end{array}$ & $\begin{array}{l}0.11 * \\
(0.06)\end{array}$ & $\begin{array}{l}0.18 * * * \\
(0.06)\end{array}$ & $\begin{array}{l}0.06 \\
(0.07)\end{array}$ & $\begin{array}{l}0.01 \\
(0.07)\end{array}$ \\
\hline Age & & & & & $\begin{array}{l}-0.01 \\
(0.01)\end{array}$ & $\begin{array}{l}-0.01 \\
(0.01)\end{array}$ & $\begin{array}{l}-0.02 * * \\
(0.01)\end{array}$ & $\begin{array}{l}0.00 \\
(0.01)\end{array}$ \\
\hline Age sq & & & & & $\begin{array}{l}0.00 \\
(0.00)\end{array}$ & $\begin{array}{l}0.00 \\
(0.00)\end{array}$ & $\begin{array}{l}0.00 * \\
(0.00)\end{array}$ & $\begin{array}{l}-0.00 \\
(0.00)\end{array}$ \\
\hline Household size & & & & & $\begin{array}{l}-0.00 \\
(0.01)\end{array}$ & $\begin{array}{l}0.01 * * \\
(0.01)\end{array}$ & $\begin{array}{l}0.00 \\
(0.01)\end{array}$ & $\begin{array}{l}0.01 \\
(0.01)\end{array}$ \\
\hline Primary education & & & & & $\begin{array}{l}-0.06 \\
(0.05)\end{array}$ & $\begin{array}{l}-0.14 * * * \\
(0.05)\end{array}$ & $\begin{array}{l}0.02 \\
(0.06)\end{array}$ & $\begin{array}{l}-0.02 \\
(0.05)\end{array}$ \\
\hline Higher than Primary education & & & & & $\begin{array}{l}-0.03 \\
(0.04)\end{array}$ & $\begin{array}{l}-0.05 \\
(0.04)\end{array}$ & $\begin{array}{l}0.05 \\
(0.04)\end{array}$ & $\begin{array}{l}0.02 \\
(0.04)\end{array}$ \\
\hline Marriage & & & & & $\begin{array}{l}0.01 \\
(0.04)\end{array}$ & $\begin{array}{l}0.04 \\
(0.04)\end{array}$ & $\begin{array}{l}0.03 \\
(0.05)\end{array}$ & $\begin{array}{l}0.01 \\
(0.05)\end{array}$ \\
\hline Group participation & & & & & $\begin{array}{l}0.09 * * \\
(0.04)\end{array}$ & $\begin{array}{l}0.08 * * \\
(0.04)\end{array}$ & $\begin{array}{l}-0.04 \\
(0.04)\end{array}$ & $\begin{array}{l}-0.05 \\
(0.05)\end{array}$ \\
\hline Farm activity & & & & & $\begin{array}{l}0.02 \\
(0.04)\end{array}$ & $\begin{array}{l}0.01 \\
(0.04)\end{array}$ & $\begin{array}{l}0.00 \\
(0.05)\end{array}$ & $\begin{array}{l}-0.03 \\
(0.04)\end{array}$ \\
\hline Own bank account & & & & & $\begin{array}{l}0.04 \\
(0.04)\end{array}$ & $\begin{array}{l}-0.01 \\
(0.04)\end{array}$ & $\begin{array}{l}-0.07 * \\
(0.04)\end{array}$ & $\begin{array}{l}0.04 \\
(0.04)\end{array}$ \\
\hline Constant & $\begin{array}{l}0.45^{* * *} \\
(0.05)\end{array}$ & $\begin{array}{l}0.38 * * * \\
(0.05)\end{array}$ & $\begin{array}{l}-0.03 \\
(0.06)\end{array}$ & $\begin{array}{l}0.01 \\
(0.05)\end{array}$ & $\begin{array}{l}0.47 * * * \\
(0.14)\end{array}$ & $\begin{array}{l}0.35^{* *} \\
(0.16)\end{array}$ & $\begin{array}{l}0.27 * \\
(0.16)\end{array}$ & $\begin{array}{l}-0.01 \\
(0.17)\end{array}$ \\
\hline Observations & 604 & 604 & 604 & 604 & 578 & 578 & 578 & 578 \\
\hline R-squared & 0.13 & 0.16 & 0.07 & 0.07 & 0.15 & 0.17 & 0.10 & 0.08 \\
\hline
\end{tabular}

Note: Robust standard errors in parentheses; $* * * \mathrm{p}<0.01,{ }^{* *} \mathrm{p}<0.05,{ }^{*} \mathrm{p}<0.1$; The sample size reduces form 604 to 578 as some of the participants failed to finish the post experimental survey.

\section{B Risk and Ambiguity Game Instruction}

You will play four different games and each time you will fill up a decision sheet with 10 different choices. At the end of the four games we will pay you for one of the games and one of the 10 choices in that game. The game and then the choice will be chosen randomly by us.

\section{Instruction for risk game:}

This bag, which we call Bag A, contains 20 balls- 10 pink and 10 yellow. Your task is to decide whether you prefer to receive a fix payment or whether you prefer to draw a ball from the bag. If the decide to draw a ball you have to guess the color before drawing. If the color, you will receive Rs. 50. If the ball has a different color, there will be no payment. 
You will be asked to take this decision for different value of the fix payment 10 times. So please pay attention while you are taking different decisions. If this game is chosen for payment we will pay you for only one of them.

You would need to register your decision using a sheet like this one. If you prefer to receive a fix payment, please mark the box on the right. If you prefer to draw a ball, please select the box in the left. When you make the draw we will ask the color before the draw. If you say pink and the ball you draw is also pink, you will gain the Rs. 50. However if the ball is yellow I do not receive any payment.

Let's look at the first decision. You can either choose to take Rs. 5 or to draw a ball from the bag. If you prefer to draw a ball, please mark the box in the left. If you want the fix amount mark the box in the right.

In the second decision you can either choose to take Rs. 10 or to draw a ball from the bag. If you prefer to draw a ball, please mark the box in the left. If you want the fix amount mark the box in right.

In the third decision you can either choose to take Rs. 15 or to draw a ball from the bag. If you prefer to draw a ball, please mark the box in the left. If you want the fix amount mark the box in the right.

In the fourth decision you can either choose to take Rs. 20 or to draw a ball from the bag. If you prefer to draw a ball, please mark the box in the left. If you want the fix amount mark the box in the right.

In the fifth decision you can either choose to take Rs. 25 or to draw a ball from the bag. If you prefer to draw a ball, please mark the box in the left. If you want the fix amount mark the box in the right.

In the sixth decision you can either choose to take Rs. 30 or to draw a ball from the bag If you prefer to draw a ball, please mark the box in the left. If you want the fix amount mark the box in the right.

In the seventh decision you can either choose to take Rs. 35 or to draw a ball from the bag. If you prefer to draw a ball, please mark the box in the left. If you want the fix amount mark the box in the right.

In the eighth decision you can either choose to take Rs. 40 or to draw a ball from the bag. If you prefer to draw a ball, please mark the box in the left. If you want the fix amount mark the box in the right.

In the ninth decision you can either choose to take Rs. 45 or to draw a ball from the bag. If you prefer to draw a ball, please mark the box in the left. If you want the fix amount mark the box in the right.

In the tenth decision you can either choose to take Rs. 50 or to draw a ball from the bag. If you prefer to draw a ball, please mark the box in the left. If you want the fix amount mark the box in the right. 
Now we would distribute the decision sheet. Please pay attention while making your decisions. Please indicate your choice for each of the 10 options. If you need assistance raise your hand we will come to you.

Now you will carry out the same task but this time you make the decision for your group. You have to decide whether you prefer to a fix payment for each person in your group or drawing of a ball from the bag that contains 10 pink balls and 10 yellow balls. If the ball that you draw has the same color as the color you guessed before drawing, each person in the group will receive Rs. 50. If the ball is yellow nobody will receive payment.

If this game is chosen for payment, we will select one member from each group and select one of the 10 choices randomly for payment. All persons in the group will receive same the payment.

Similarly, as before you need to mark your decision using this decision sheet. If you prefer the fix payment for all persons in your group please mark the right box. If you prefer to draw a ball, please market in the right box.

\section{Instruction for ambiguity game:}

Consider this bag which we call bag B. In bag B there 20 balls- pink and yellow balls, however, you will not know how many pink and how many yellow balls are there in the bag. Only information you have now is that there are 20 balls. We again ask you to make your choice between a fix amount and drawing of a ball. As before first you will make the decision for yourself then on behalf of the group. Each time you will fill up a decision sheet with 10 options.

Repeat the individual game and then the group game

Thank you for participating in the game. 


\section{Curricula Vitae}

Debosree Banerjee

September, 2014

University of Göttingen,

GlobalFood Research Training Group

Heninrich-Düker-Weg 12, Room 0.224

37073, Germany email: debosree.banerjee@agr.uni-

goettingen.de

Office Phone: +49-551-3920210

Mobile Phone: +49-176-30426545

RESEARCH FIELD: Development Economics, Experimental Economics.

PHD THESIS: Essays on Women's Empowerment in Developing Countries

\section{EDUCATION:}

2011-2014: PhD in Economics, University of Göttingen, Germany.

2009-2011: MA in Economics, University of Tsukuba, Japan.

2005-2007: MPhil in Economics, Jawaharlal Nehru University New Delhi, India.

2003-2005: MA in Economics, Jawaharlal Nehru University New Delhi, India.

2000-2003: BSc in Economics, Calcutta University, Calcutta, India.

\section{RESEARCH EXPERIENCE:}

University of Tsukuba, Japan (M.A. Thesis): Investigating the Role of Women in Children's Human Capital Development: Evidence from India.

Jawaharlal Nehru University, India. (M.Phil. Thesis): Health Inputs, Health Outcomes and Economic Performance: Evidence from Indian States.

\section{WORKING PAPERS:}

Banerjee, D., Klasen, S., Wollni, M (2014). Market Discrimination, Market Participation and Control over Revenue: A Gendered Analysis of Cameroon's Cocoa Producers. GlobalFood Discussion Paper Series No. 43. University of Göttingen.

Banerjee, D (2014). Ethnicity and Gender Differences in Risk, Ambiguity Attitude GlobalFood Discussion Paper Series.No. 42. University of Göttingen.

\section{WORK IN PROGRESS:}

Banerjee, D., Ibanez, M., Reiner, G., Wollni, M (2014). Running for Leadership: Evidence from an artefactual field experiment in matrilineal and patriarchal societies in India. 


\section{FIELD EXPERIENCE:}

August, 2012-March, 2013: Conducted field experiments in West Bengal and Meghalaya, India.

Collected primary data for the PhD projects: (1) Running for Leadership: Evidence from an artefactual field experiment in matrilineal and patriarchal societies in India, using public good game with 616 people (2) Ethnicity and Gender Differences in Risk, Ambiguity Attitude, using Ellsberg game with 604 people.

April, 2006: Conducted field survey in Odissa, India for Voluntary Health Association, of India (VHAI), New Delhi, India.

Collected primary data from PHCs and SSCs on various aspects of health financing issue in Odissa for the project: Health expenditure and Health output.

\section{SCHOLARSHIPS/ FUNDINGS}

December, 2012-March, 2013: Field experiment fund and travel grant received from University of Göttingen, GlobalFood Research Training Group.

August, 2012-November, 2012: Field experiment fund received from University of Göttingen, GlobalFood Research Training Group.

August, 2012-November, 2012: Travel grand received from University of Göttingen, International office for research stay in India.

April2009-March, 2011:Scholarship received from Joint Japan/World Bank Graduate Scholarship Program for MA in Economics, University of Tsukuba, Japan.

2005-2007: Fellowship received from University Grant Commission for MPhil in Economics, Jawaharlal Nehru University, India

\section{CONFERENCE/PRESENTATION}

2014: The $11^{\text {th }}$ Workshop on Social Economy for Young Economists, University of Bologna, Italy. Paper presented: Ethnicity and Gender Differences in Risk, Ambiguity Attitude.

2014: GlobalFood Symposium, University of Göttingen, Germany, Paper presented: Market discrimination, Market Participation and Control over Revenue: A Gendered Analysis of Cameroon's Cocoa Producers.

2013: SEEDEC Conference, NHH Norwegian School of Economics, Norway, Paper presented: Running for Leadership: Evidence from an artefactual field experiment in matrilineal and patriarchal societies in India.

2013: IAFFE Conference, Stanford University, USA, Paper presented: Running for Leadership: Evidence from an artefactual field experiment in matrilineal and patriarchal societies in India.

2011: Knowledge Sharing Forum organized by World Bank Institute and World Bank Tokyo, Ritsumeikan University, Tokyo, Japan. Paper presented: Investigating the Role of Women in Children's Human Capital Development: Evidence from India. 


\section{WORK EXPERIENCE}

2011-onwardrs: Research Associate, GlobalFood Research Training Group, University of Göttingen, Germany.

2008-2009: Research Associate, Indian Council for Research on International Economic Relations (ICRIER), New Delhi, India.

2007: Research Associate, Voluntary Health Association of India, New Delhi, India.

2005-2006: Research Assistant, Rajeev Gandhi Foundation, New Delhi, India.

TECHNICAL SKILLS: STATA; Eviews 